\title{
Water Withdrawals, Use, and Trends in Florida, 2005
}

By Richard L. Marella

Prepared in cooperation with the

Florida Department of Environmental Protection

Scientific Investigations Report 2009-5125 


\section{U.S. Department of the Interior \\ KEN SALAZAR, Secretary \\ U.S. Geological Survey \\ Marcia K. McNutt, Director}

U.S. Geological Survey, Reston, Virginia: 2009

For more information on the USGS—-the Federal source for science about the Earth, its natural and living resources,
natural hazards, and the environment, visit http://www.usgs.gov or call 1-888-ASK-USGS
For an overview of USGS information products, including maps, imagery, and publications,
visit http://www.usgs.gov/pubprod
To order this and other USGS information products, visit http://store.usgs.gov

Any use of trade, product, or firm names is for descriptive purposes only and does not imply endorsement by the U.S. Government.

Although this report is in the public domain, permission must be secured from the individual copyright owners to reproduce any copyrighted materials contained within this report.

Suggested citation:

Marella, R.L., 2009, Water withdrawals, use, and trends in Florida, 2005: U.S. Geological Survey Scientific Investigations Report 2009-5125, 49 p. 


\section{Acknowledgments}

The author gratefully acknowledges the Florida Department of Environmental Protection (FDEP), Office of Water Policy, for its cooperation in the State Water-Use Program, and extends a special thanks to the following individuals who provided program support or data and technical assistance: Janet Llewellyn, Joseph Doker, Lauren Walker-Coleman, Kathleen Greenwood, Kenna Study, Thomas Swihart, and Carolyn Voyles (Tallahassee), as well as the many individuals in the Drinking Water and Wastewater Programs from FDEP district offices in Ft. Myers, Jacksonville, Orlando, Pensacola, Tampa, and West Palm Beach. Other State of Florida agencies that contributed assistance or data include the Florida Department of Agricultural and Consumer Services and the Florida Department of Health.

Special appreciation is extended to the Executive Directors of the five Florida Water Management Districts (WMDs) for their participation and staff cooperation in providing water-use data: Northwest Florida WMD (NWFWMD), St. Johns River WMD (SJRWMD), South Florida WMD (SFWMD), Southwest Florida WMD (SWFWMD), and the Suwannee River WMD (SRWMD). The participation of the following individuals is acknowledged for their data-collection and tabulation efforts or for their technical input and support: Angela Chelette, Kathleen Coates, Christina Coger, Lauren Connell, Janet Dettle, and the late Marvin Raulston at NWFWMD in Havana; Bruce Florence and Penni Hauck at SJRWMD in Palatka; Kurt Leckler and his staff (Jay Floyd, the late Barbara Fronczek, Krista Guerrero, Clayton McMillan, Stephanie Lancaster, William Rasperger, and Curtis Thompson) and Jane Bucca and her staff (Jianchang Cia, Morris Rosen, and Carl Woehlcke) at SFWMD in West Palm Beach; Mehrshad Nourani and Kathleen Scott at SWFWMD in Brooksville; Kirk Webster and Glenn Horvath at SRWMD in Live Oak.

Appreciation is also extended to the many utility operators, plant managers, and individuals who provided data vital to the completion of this effort. These include staff from: Bay County Public Utilities, Florida Power and Light Company, Progress Energy (formerly Florida Power Corporation), Florida Rock Industries, Gainesville Regional Utilities, Gulf Power Company (A Southern Company), Jacksonville Electric Authority, Lakeland Electric and Water, Miami-Dade Water and Sewer Department, Orange County Water and Sewer Department, Orlando Utilities Commission, Palm Beach County Water Utilities Department, Tampa Bay Water, Tampa Electric Company, City of Tallahassee, and many others who provided data and technical guidance. 



\section{Contents}

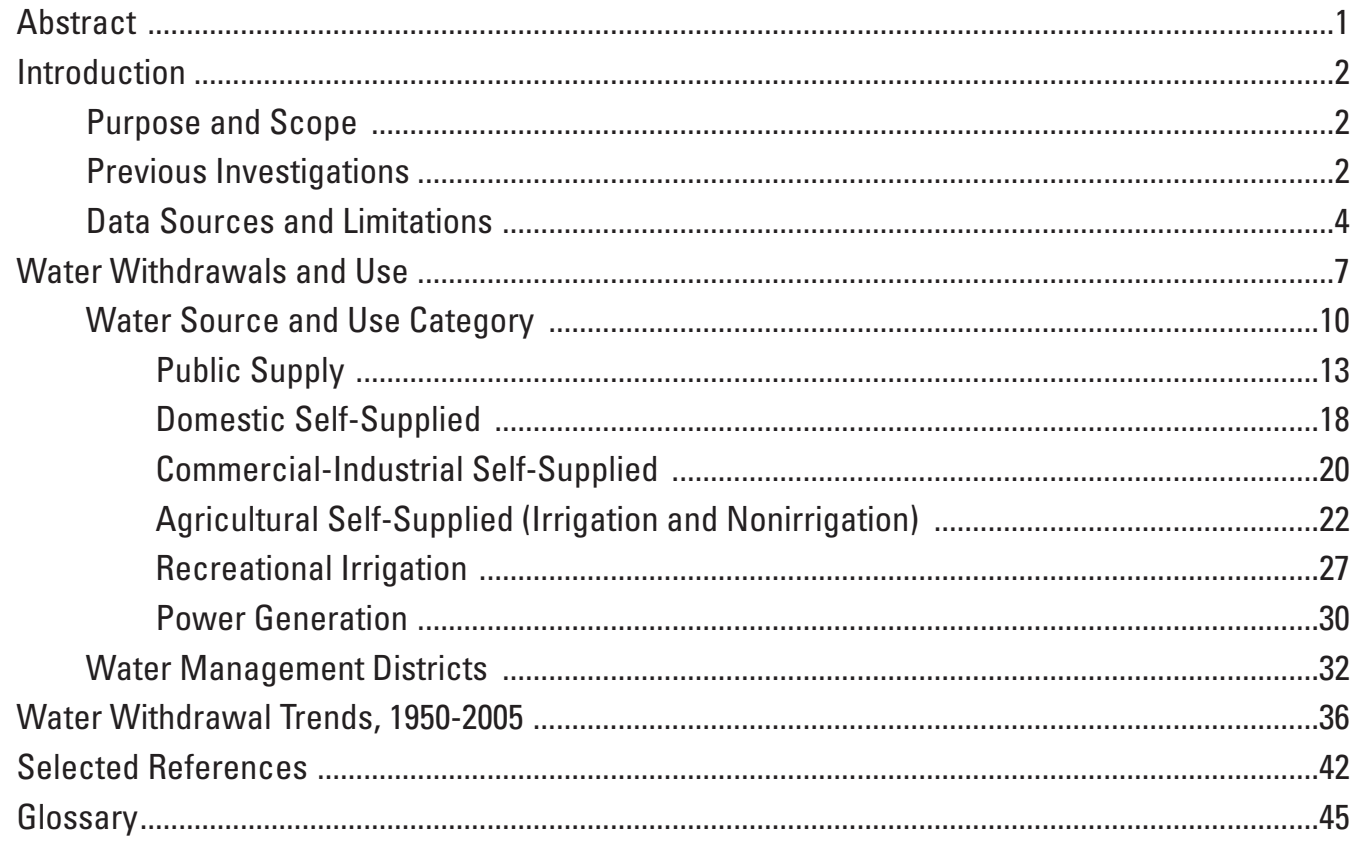

\section{Figures}

1. Graph showing historical and projected population of Florida, 1950-2030 .......................2

2. Map showing counties and water management districts in Florida...................................3

3-5. Graphs showing:

3. Total water withdrawals in Florida by source, 2005 ....................................................

4. Average daily freshwater withdrawals by month in Florida, 2005 .................................8

5. Fresh groundwater and surface-water withdrawals in Florida by

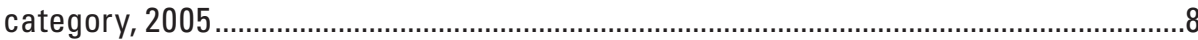

6. Map showing approximate areal extent throughout which principal aquifers in Florida are the primary source of groundwater, and quantity of groundwater withdrawals, 2005

7. Map showing general location of hydrologic units in Florida and fresh groundwater and surface-water withdrawals within these units, 2005

8-39. Graphs showing:

8. Public-supply groundwater withdrawals in Florida by principal aquifer, 2005

9. Average daily public-supply freshwater withdrawals

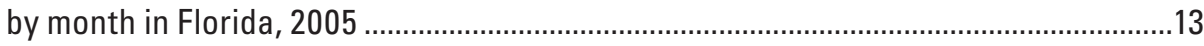

10. Public-supply water-use deliveries in Florida, 2005 ...............................................15

11. Historical public-supply gross and domestic per capita water use in Florida, 1950-2005.

12. Historical public-supply freshwater withdrawals in Florida by source, 1950-2005. 
13. Domestic self-supplied groundwater withdrawals in Florida by principal aquifer, 2005

14. Historical domestic self-supplied freshwater withdrawals in Florida, 1950-2005

15. Commercial-industrial self-supplied groundwater withdrawals in Florida by principal aquifer, 2005 .

16. Average daily commercial-industrial self-supplied freshwater withdrawals by month in Florida, 2005 .

17. Commercial-industrial self-supplied freshwater use in Florida by major industrial type, 2005.

18. Historical commercial-industrial self-supplied freshwater withdrawals in Florida by source, 1950-2005.

19. Agricultural self-supplied groundwater withdrawals in Florida by principal aquifer, 2005

20. Average daily agricultural self-supplied freshwater withdrawals by month in Florida, 2005

21. Agricultural self-supplied freshwater use in Florida by major crop type, 2005.......... 24

22. Historical agricultural self-supplied freshwater withdrawals in Florida by source, 1950-2005.

23. Historical agricultural acreage in Florida for selected crops, 1970-2006.

24. Historical agricultural acreage irrigated in Florida by major irrigation system type, 1980-2005.

25. Recreational irrigation groundwater withdrawals in Florida by principal aquifer, 2005

26. Average daily recreational irrigation freshwater withdrawals by month in Florida, 2005.

27. Historical recreational irrigation freshwater withdrawals in Florida by source, 1985-2005.

28. Average daily power-generation freshwater withdrawals by month in Florida, 2005.

29. Historical power-generation water withdrawals in Florida by source, 1950-2005

30. Population and population served by public supply in Florida by water management district, 2005

31. Freshwater withdrawals in Florida by water management district, 2005.

32. Freshwater and saline-water withdrawals in Florida by water management district, 2005

33. Historical freshwater withdrawals in Florida by water management district, 1975-2005

34. Historical fresh groundwater withdrawals in Florida by water management district, 1975-2005.

35. Historical fresh surface-water withdrawals in Florida by water management district, 1975-2005.

36. Freshwater withdrawals for agricultural self-supplied and public supply with statewide average annual rainfall in Florida, 1980-2005

37. Historical total population, freshwater, and saline-water withdrawals in Florida, 1950-2005..

38. Historical freshwater withdrawals in Florida by source, 1950-2005 ........................... 37

39. Historical freshwater withdrawals in Florida by category, 1975-2005... 


\section{Tables}

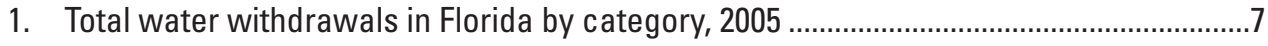

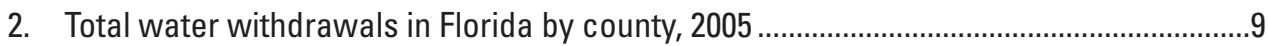

3. Total groundwater withdrawals by principal aquifer in Florida by county, 2005.

4. Public-supplied population, water use, withdrawals, transfers, and treated water in Florida by county, 2005 ..........................................................................14

5. Estimated public-supply water use (deliveries), and per capita use in Florida

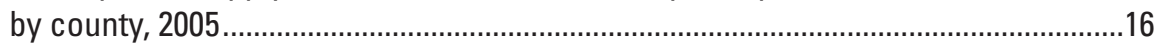

6. Domestic self-supplied population and water withdrawals in Florida by county, 2005

7. Commercial-industrial self-supplied (includes mining) water withdrawals in Florida by county, 2005 . .21

8. Agricultural self-supplied water withdrawals in Florida by county, 2005 .......................23

9. Acres irrigated, irrigation system type, and water use by crop type in Florida, 2005. . .25

10. Recreational irrigation water withdrawals in Florida by county, 2005...........................28

11. Power-generation water withdrawals in Florida by county, 2005 .................................31

12. Water withdrawals by category in Florida by water management

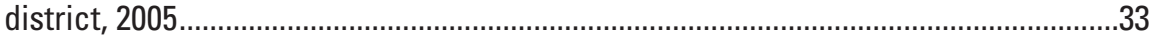

13. Historical population and water withdrawals in Florida by source, 1950-2005 ................38

14. Historical freshwater withdrawals in Florida by category, 1970-2005 .............................40 


\section{Conversion Factors and Abbreviations}

\begin{tabular}{rcl} 
Multiply & By & To obtain \\
& Area & \\
acre (ac) & 4,047 & square meter \\
acre (ac) & 0.00156 & square mile \\
inch (in.) & 25.4 & millimeter \\
mile (mi) & 1.608 & kilometer \\
& Flow rate & \\
gallon per day (gal/d) & 3.785 & liter per day \\
million gallons per day (Mgal/d) & 0.003785 & million cubic meters per day \\
& Energy & \\
gigawatt-hour (GWh) & 0.001 & megawatt-hour \\
\hline & &
\end{tabular}

\section{Acronyms}

$\begin{array}{rll}\text { AFSIRS } & \text { Agricultural Field Scale Irrigation Requirements Simulation } \\ \text { FDACS } & \text { Florida Department of Agriculture and Consumer Services } \\ \text { FDEP } & \text { Florida Department of Environmental Protection } \\ \text { NWFWMD } & \text { Northwest Florida Water Management District } \\ \text { SJRWMD } & \text { St. Johns River Water Management District } \\ \text { SFWMD } & \text { South Florida Water Management District } \\ \text { SWFWMD } & \text { Southwest Florida Water Management District } \\ \text { SRWMD } & \text { Suwannee River Water Management District } \\ \text { USGS } & \text { U.S. Geological Survey } \\ \text { WMD } & \text { Water Management District }\end{array}$

Acronyms shown as affiliations in written commun., for consistency. 


\title{
Water Withdrawals, Use, and Trends in Florida, 2005
}

\author{
By Richard L. Marella
}

\section{Abstract}

In 2005, the total amount of water withdrawals in Florida was estimated at 18,359 million gallons per day (Mgal/d). Saline water accounted for $11,486 \mathrm{Mgal} / \mathrm{d}$ (63 percent), and freshwater accounted for $6,873 \mathrm{Mgal} / \mathrm{d}$ (37 percent). Groundwater accounted for $4,247 \mathrm{Mgal} / \mathrm{d}$ (62 percent) of freshwater withdrawals, and surface water accounted for the remaining $2,626 \mathrm{Mgal} / \mathrm{d}$ (38 percent). Surface water accounted for nearly all (99.9 percent) saline-water withdrawals. An additional $660 \mathrm{Mgal} / \mathrm{d}$ of reclaimed wastewater was used in Florida during 2005. The largest amount of freshwater was withdrawn from Palm Beach County, and the largest amount of saline water was withdrawn from Pasco County.

Fresh groundwater provided drinking water (public supplied and self-supplied) for 16.19 million people (90 percent of Florida's population), and fresh surface water provided drinking water for 1.73 million people (10 percent). The majority of groundwater withdrawals (nearly 60 percent) in 2005 was obtained from the Floridan aquifer system which is present throughout the entire State. The majority of fresh surface-water withdrawals (59 percent) came from the southern Florida hydrologic unit subregion and is associated with Lake Okeechobee and the canals in the Everglades Agricultural Area of Glades, Hendry, and Palm Beach Counties, as well as the Caloosahatchee River and its tributaries in the agricultural areas of Collier, Glades, Hendry, and Lee Counties.

Overall, agricultural irrigation accounted for 40 percent of the total freshwater withdrawals (ground and surface), followed by public supply with 37 percent. Public supply accounted for 52 percent of groundwater withdrawals, followed by agricultural self-supplied (31 percent), commercial-industrialmining self-supplied (8.5 percent), recreational irrigation and domestic self-supplied (4 percent each), and power generation (0.5 percent). Agricultural self-supplied accounted for 56 percent of fresh surface-water withdrawals, followed by power generation (20.5 percent), public supply (13 percent), recreational irrigation (6 percent), and commercial-industrial self-supplied (4.5 percent). Power generation accounted for nearly all (99.9 percent) saline-water withdrawals.
Of the 17.92 million people who resided in Florida during 2005, 41 percent (7.36 million people) resided in the South Florida Water Management District (SFWMD), followed by the St. Johns River Water Management District (SJRWMD) and the Southwest Florida Water Management District (SWFWMD) with 25 percent each (4.46 and 4.44 million people, respectively), the Northwest Florida Water Management District (NWFWMD) with 7.5 percent (1.34 million people), and the Suwannee River Water Management District (SRWMD) with 1.5 percent ( 0.32 million people). The largest amount of freshwater withdrawals was from the SFWMD, which was one-half (50 percent) of the State's total freshwater withdrawals, followed by the SJRWMD (19 percent), SWFWMD (16 percent), NWFWMD (10 percent), and SRWMD (5 percent).

Between 1950 and 2005, the population of Florida increased by 15.15 million (550 percent), and the total water withdrawals (fresh and saline) increased 15,700 Mgal/d (600 percent). More recently, total withdrawals decreased 1,790 Mgal/d (9 percent) between 2000 and 2005, but the total population increased by 1.94 million (12 percent). Between 1990 and 2005, saline-water withdrawals increased $1,120 \mathrm{Mgal} / \mathrm{d}$ (11 percent), whereas between 2000 and 2005, saline-water withdrawals decreased $470 \mathrm{Mgal} / \mathrm{d}$ (4 percent). Between 1990 and 2005, freshwater withdrawals decreased $710 \mathrm{Mgal} / \mathrm{d}$ (9 percent), whereas between 2000 and 2005, freshwater withdrawals decreased 1,320 Mgal/d (16 percent).

The use of highly mineralized groundwater as a source of supply, primarily for public supply, also has increased in Florida. This water, referred as nonpotable water, increased from just less than $2 \mathrm{Mgal} / \mathrm{d}$ in 1970, to $142 \mathrm{Mgal} / \mathrm{d}$ in 2005 . Nonpotable water is treated to meet drinking-water standards and is mostly used along the east and west coasts of central and south Florida. The use of reclaimed wastewater increased from $206 \mathrm{Mgal} / \mathrm{d}$ in 1986 to nearly $660 \mathrm{Mgal} / \mathrm{d}$ in 2005 . About one-half of the reclaimed wastewater flow in 2005 was used to reduce potable-quality water withdrawals for urban irrigation, agricultural irrigation, and industrial use, but one-third of the reclaimed wastewater was returned to available water supplies as aquifer recharge. 


\section{Introduction}

Water is among Florida's most valued resources. The State has more than 1,700 streams and rivers, 7,800 freshwater lakes, 700 springs, 11 million acres of wetlands, and underlying aquifers yielding significant quantities of freshwater necessary for human and environmental needs (Fernald and Purdum, 1998). Although renewable, these water resources are finite, and continued growth in population, tourism, and agriculture will place increased demands on these water sources.

The resident population of Florida in 2005 totaled 17.92 million (University of Florida, 2006), ranking fourth in the Nation (U.S. Census Bureau, 2006a). This represents an increase in population of about 550 percent from the 1950 population of 2.77 million (Dietrich, 1978), and a 12 percent increase from the 2000 population of 15.98 million (University of Florida, 2006) (fig. 1). Florida's population is projected to reach nearly 20 million by the year 2010, and nearly 24 million by the year 2020 (Smith and Rayer, 2007) (fig. 1). In addition to the State's resident population, nearly 86 million people visited Florida in 2005 (Orlando Business Journal, 2006). Freshwater is vital for Florida's permanent and seasonal residents, and demands will continue to increase.

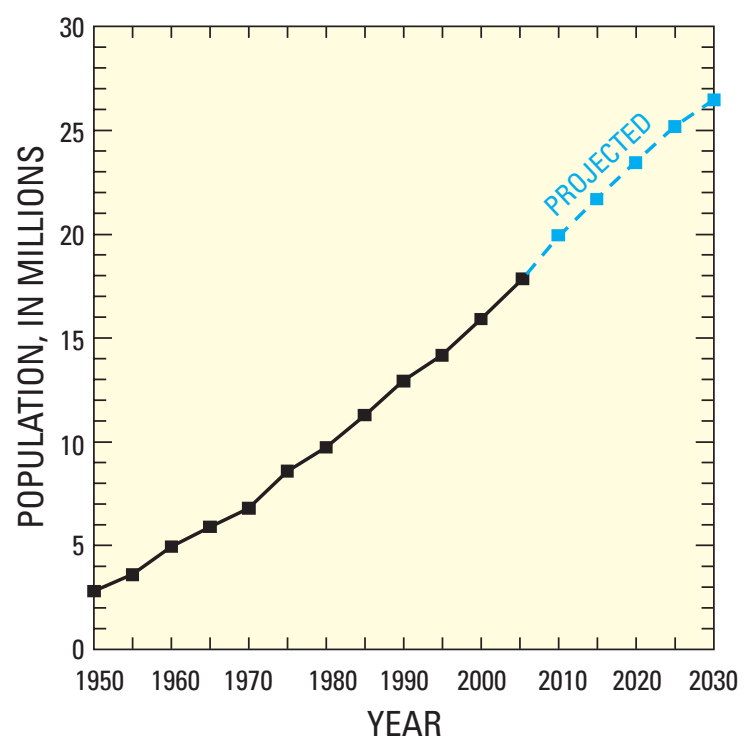

Figure 1. Historical and projected population of Florida, 1950-2030. From Dietrick (1978), University of Florida (2006), and Smith and Rayer (2007).

The agricultural sector in Florida also depends heavily on the State's water resources. In 2005, Florida produced two-thirds (67 percent) of the total citrus produced in the United States, and ranked fifth in the Nation in all crops with receipts, and tenth in total cash receipts (Florida Department of Agriculture and Consumer Services, 2006). Agricultural production is expected to increase because of the subtropical climate and demands from the growing population. Information on the amount of water required to support future agricultural growth is needed.
Accurate estimates reflecting water use and trends in Florida are compiled by the U.S. Geological Survey (USGS), in cooperation with the Florida Department of Environmental Protection (FDEP), Northwest Florida Water Management District, St. Johns River Water Management District, South Florida Water Management District, Southwest Florida Water Management District, and Suwannee River Water Management District. This coordinated effort provides the necessary data and information for planning future water needs and resource management in Florida. Water-use estimates for Florida are presented in this report by category, county, water source, and water management district (WMD).

\section{Purpose and Scope}

Water-use data for 2005 were summarized and published in a USGS fact sheet (Marella, 2008); however, this report provides far greater detail on the quantities of water withdrawn in 2005 and on trends in water use between 1950 and 2005. Overall, the report provides a basis for estimating water budgets and projecting future water needs. Data are presented on water withdrawals in Florida for each of the following water use categories: public supply, domestic self-supplied, commercial-industrial self-supplied (including mining uses), agricultural self-supplied (including irrigation and nonirrigation uses), recreational irrigation (including golf-course irrigation), and power generation. Data are not presented for instream (nonwithdrawal) water use, such as hydroelectric power generation, navigation, water-based recreation, propagation of fish and wildlife, and dilution and conveyance of liquid or solid waste. This report also does not include data on the amount of water discharged from wastewater-treatment facilities, septic tanks, or retention ponds.

Within each category, withdrawal data are presented by source (ground or surface water) and, where sufficient data are available, seasonal and historical patterns of water use are described. Data also are presented by county and WMD (fig. 2) for each water-use category. Information about specific public-supply water systems and domestic wastewater facilities can be obtained by contacting the USGS office in Tallahassee or by visiting the USGS website at http://fl.water.usgs.gov/infodata/wateruse.html.

\section{Previous Investigations}

This report is the tenth in a series of reports documenting the results of water-use investigations in Florida. Statewide water-use data for Florida were published for 1965 and 1970 (Pride, 1973, 1975); for 1975, 1977, and 1980 (Leach, 1978, 1983; and Leach and Healy, 1980); and for 1985, 1990, 1995, and 2000 (Marella, 1988, 1992, 1999, 2004). These reports included assessments of all water uses in Florida, by county, for the following categories: publicsupply, domestic self-supplied, commercial-industrial self-supplied, agricultural irrigation and nonirrigation, 


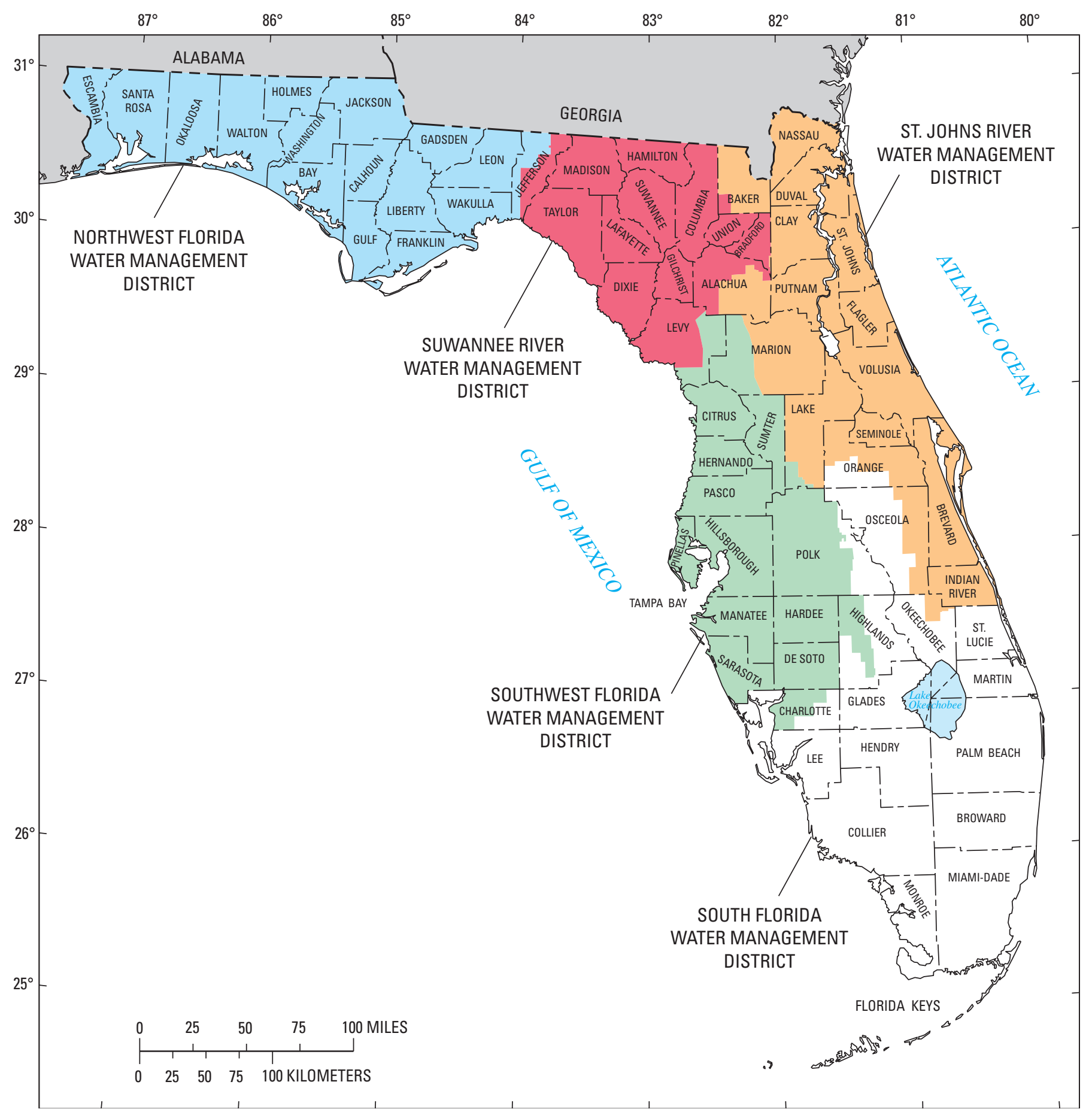

Figure 2. Counties and water management districts in Florida. Modified from Fernald and Purdum, 1998.

recreational irrigation, and power-generation. Historical water-use data for Florida and each county for all freshwater withdrawals by category between 1965 and 2005 are available from the USGS Florida Water Science Center website at http://fl.water.usgs.gov/infodata/wateruse.html

Prior to 1965 , state water-use data were only published at the national level. Nationwide summaries of water-use data were published for 1950, 1955, and 1960 (MacKichan, 1951, 1957; and MacKichan and Kammerer, 1961). These reports included detailed water-use data at the state level, but did not include water-use data for counties. Nationwide summaries, including data for Florida, also were published by the USGS for 1965, 1970, 1975 (Murray, 1968; and Murray and Reeves, 1972, 1977); for 1980, 1985, 1990, 1995 (Solley and others, 1983, 1988, 1993, 1998), and for 2000 (Hutson and others, 2004) and 2005 (Kenny and others, 2009). National and state data for 2005 and prior years are available on the USGS National web page http://water.usgs.gov/watuse/. 
Additional water-use reports have been published by selected WMDs between 1975 and 2005. SJRWMD and SWFWMD have published annual water-use reports since 1977; NWFWMD, SFWMD, and SRWMD have intermittently published reports between 1977 and 1985. Detailed water-use data for 2005 were published by SWFWMD (2007), and a summary fact sheet for 2005 was published by SJRWMD (2006). Historical water-use data for all freshwater between 1975 and 2005 for each WMD are available at the USGS Florida Water Science Center website at http://fl.water.usgs.gov/infodata/wateruse. In addition, a complete water-use bibliography for Florida is available at this website.

\section{Data Sources and Limitations}

As part of the USGS National Water-Use Information Program, water-use data are collected and compiled for each state every 5 years (Solley and others, 1988). Data for 2005 were collected under the guidelines provided by the USGS (Hutson, 2007). Data for each state are reported by major water-use category and county with some states also reporting by hydrologic unit (basin) and aquifer. Water-use data for Florida were compiled through an ongoing cooperative program with the FDEP as part of the 2005 National Water-Use Information Program. Data also were obtained from FDEP (Drinking Water and Wastewater Sections), NWFWMD, SRWMD, SJRWMD, SWFWMD, and SFWMD, as well as from various utilities, industries, and power companies. Specific data sources for each category or source are listed below.

Public supply.-Data for public-supply withdrawals were obtained from FDEP's Drinking Water Section (monthly operating reports), the five WMDs (consumptive water-use permit files or annual reports), or directly from the water supplier. All water-use values for this category are from metered data.

The population served value for each public supplier was determined by one of three methods: (1) estimated using the number of service connections (obtained from FDEP monthly operating reports) multiplied by the number of people per household per county (Smith and Cody, 2006); (2) estimated from published population studies for selected cities (University of Florida, 2006); and (3) estimated by the individual WMDs from their water-supply planning documents. Population served values in NWFWMD and SRWMD were estimated by the USGS from data obtained from FDEP. Population estimates for SFWMD were obtained from their Water Supply Plans and compiled by the USGS. Estimates for population served by SJRWMD and SWFWMD were made by the respective district (St. Johns River Water Management District, 2006; Southwest Florida Water Management District, 2007). Values for SWFWMD were modified to remove seasonal population estimates so they would be consistent with the other four WMDs.

Domestic self-supplied.-Domestic self-supplied populations are derived by subtracting the population served by the public-supply systems from the total county population. Domestic self-supplied withdrawals are calculated by multiplying the 2005 statewide domestic per capita use of $95 \mathrm{gal} / \mathrm{d}$ by the self-supplied population served for each county (detailed in the public-supply section). Withdrawal estimates for the counties within SJRWMD and SWFWMD were calculated by the districts using the public supply per capita or an adjusted per capita (St. Johns River Water Management District, 2006; Southwest Florida Water Management District, 2007). All water used for domestic self-supplied is assumed to be obtained from groundwater. Values for this category are estimated.

Commercial-industrial self-supplied.-Data for commercial, industrial, and mining withdrawals were obtained from FDEP's Drinking Water Section (monthly operating reports), the five WMDs (consumptive water-use permit files or annual reports), or directly from the user. Most of the water-use values for this category are from metered data.

Agricultural self-supplied.-Water withdrawals for irrigation were estimated by using irrigated crop acreage multiplied by a use coefficient (usually in inches per acre) generated from selected irrigation models for each crop. Withdrawal estimates for NWFWMD, SFWMD, and SRWMD were made by the USGS. Estimates for SJRWMD and SWFWMD were provided by these agencies. Only a small percentage (about 10 to 15 percent) of the water-use estimates in 2005 for agricultural self-supplied were derived from actual metered data.

Acreage data were obtained by the USGS and WMDs from a variety of sources: (1) Florida Department of Agriculture and Consumer Services (FDACS), Florida Agricultural Statistics Service (Florida Department of Agriculture and Consumer Services, 2006); (2) U.S. Department of Agriculture, 2002 Census of Agriculture, Florida (U.S. Department of Agriculture, 2004); (3) WMDs' consumptive water-use permit files; (4) WMDs' water-supply plans along with their needs and sources documents; and (5) University of Florida, Institute of Food and Agriculture Science, County Extension Offices. The data obtained for each crop from the 2002 Census of Agriculture were updated with totals from the Florida Agricultural Statistic Service to reflect 2005 information. The total number of acres for selected crops for each county was obtained from these sources, as well as the acreage that was irrigated. These crops include: vegetables (cabbage/lettuce, cucumbers/pickles, peppers, sweet corn, tomatoes, watermelons/cantaloupes, and many other small vegetables); fruit crops (blueberries, citrus, grapes, peaches, strawberries, and other fruit-bearing crops or trees); field crops (cotton, field corn, peanuts, potatoes, rice, soybeans, sugarcane, tobacco, wheat, and other field-based crops, including seeds); ornamentals (field grown, greenhouse grown, and container grown); and grasses (pasture, hay, and sod).

The supplemental irrigation coefficient used to determine the amount of water needed per crop was obtained from the Agricultural Field Scale Irrigation Requirements Simulation (AFSIRS) model (Smajstrla, 1986). Other models that also may have provided some coefficients include the modified Blaney-Criddle irrigation model, the U.S. Soil Conservation Service "Irrigation Water Requirements, 1970, revised" (U.S. 
Soil Conservation Service, 1970), and the "Florida Irrigation Guide" (U.S. Soil Conservation Service, 1982). In some cases, actual metered data may have been used to determine supplemental irrigation coefficients for selected crops within some WMDs. For 2005, AFSIRS was the primary source of most coefficients in all five WMDs, compared to previous years when Blaney-Criddle also was used to provide many coefficients.

Supplemental irrigation application rates (in inches per acre) generated from these sources were multiplied by the number of irrigated acres to yield water-use estimates. From these values, estimates of the water sources (ground or surface) were made by using information from WMD consumptive water-use permit files or were obtained from previous year's data. Supplemental irrigation rates include the amount of water needed to grow each crop, the amount of water necessary to overcome the inefficiency of the irrigation system, and water used for frost and freeze protection.

Withdrawal estimates for livestock and fish farming were provided by the USGS (John Lovelace, USGS, written commun., 2007) and (Lovelace, 2009 a and b) or obtained from the WMDs. Estimates for livestock and fish farming were made by the WMDs from their consumptive water permits for those counties within NWFWMD, SFWMD, and SRWMD. Values for SWFWMD were obtained from that agency's 2005 wateruse report (Southwest Florida Water Management District, 2007, app. A). No withdrawal estimates for livestock or fish farming were made for 2005 by SJRWMD.

Recreational irrigation.-Recreational irrigation includes the application of water on lands to assist in the growing of turf grass and landscape vegetation for lawns or recreation purposes, and also includes water used for aesthetic purposes. Turf-grass recreation includes the golf-course irrigation (including all grass and landscape associated with golf courses), and all grass and landscape irrigation associated with athletic fields, cemeteries, common public or highway areas, parks, playgrounds, and lawns (primarily nonresidential, but may include some residential lawns).

Water withdrawals for recreational irrigation were estimated by using irrigated acreage multiplied by a use coefficient (usually in inches per acre) generated from selected irrigation models for each crop. Withdrawal estimates for NWFWMD, SFWMD, and SRWMD were made by the USGS. Estimates for SJRWMD and SWFWMD were provided by these agencies. Only a small percentage (about 10 to 15 percent) of the water-use estimates for 2005 were derived from actual metered data.

Acreage data were obtained by the USGS and WMDs from a variety of sources, including the National Golf Foundation (2006); and the WMDs' consumptive water-use permit files, water-supply plans, and their needs and sources documents. Acreage data for golf courses were estimated from the number of golf-course holes per county multiplied by 6 acres per hole and 5 acres per hole irrigated. All other acreage data were obtained from the WMDs.
The supplemental irrigation coefficient used to determine the amount of water needed per crop was obtained from the AFSIRS model (Smajstrla, 1986). Other models that also may have provided some coefficients include the modified BlaneyCriddle irrigation model, or the U.S. Soil Conservation Service "Irrigation Water Requirements, 1970, revised" (U.S. Soil Conservation Service, 1970), or the "Florida Irrigation Guide" (U.S. Soil Conservation Service, 1982). In some cases, actual metered data may have been used to determine supplemental irrigation coefficients for turf grass within some WMDs.

Supplemental irrigation application rates (in inches per acre) generated from these sources were multiplied by the number of irrigated acres, and a water-use value was calculated. From this value, estimates of the water sources (ground or surface) were provided by the WMDs' consumptive water-use permit files.

Power generation.-Data for power-generation withdrawals were obtained by the USGS directly from the power companies. Some additional data were obtained from the WMDs (consumptive water-use permit files or annual reports) or the Energy Information Administration database of the U.S. Department of Energy (Susan Hutson, USGS, written commun., 2007). Withdrawal data were collected for ground and surface waters, both fresh and saline sources. Information on the amount of water purchased from public supplies was obtained from each facility along with the total gross power generated. Most of the water-use values for this category are from metered data.

Wastewater discharges.-Data for domestic, industrial, and septic-tank wastewater discharges were not available for this report. Wastewater totals for 2005 are being collected and compiled and will be made available sometime after this report is published at the USGS web page http://fl.water.usgs.gov/infodata/wateruse. Information on water reuse was obtained from the FDEP's Domestic Wastewater Section, 2005 Reuse Inventory (Florida Department of Environmental Protection, 2006).

Aquifer withdrawals. - Estimates of water withdrawals by aquifer were made for each category. For public supply, commercial-industrial self-supplied, and power generation, information for the primary aquifer used for each well field or facility was obtained by permit from the WMDs' consumptive water-use permit file. Estimates were made for domestic selfsupplied, agricultural self-supplied, and recreational irrigation by using information obtained from several groundwater studies conducted throughout the State that detailed estimates of withdrawals for selected aquifers in specific counties or areas (Duerr and others, 1988, Knowles and others, 2002, Sepulveda, 2002, and Shoemaker and Edwards, 2003) or were made from information obtained from local county agencies (Florida Department of Health, County Health Department, Environmental Permitting) that regulate private well construction. In counties with no information, estimates were made by assuming that 90 percent of water withdrawals were from the primary aquifer used for public supply and the remaining 10 percent from the local water table or shallow aquifer. 
Accuracy.-Water withdrawals and use data presented in this report represent the average daily quantities used, calculated from monthly totals or derived from annual totals, and are expressed in million gallons per day. Water-use values presented in the tables are reported to two places to the right of the decimal or to the nearest 10,000 gal/d. Water-use values in the text are rounded to the nearest million gallons per day, and percentages are rounded. Water-use data published in this report may not be identical to the water-use data published by the WMDs or FDEP because of differences in data-collection procedures, categories, and methodology. In addition, some values in this report may differ from those published earlier for 2005 (Marella, 2008), as new or additional data were obtained between the printing of that report and the completion of this report.

The accuracy of these values varies by category. Public-supply values usually are more accurate because most public-supply systems meter water usage, whereas agricultural self-supplied or domestic self-supplied values usually are estimated. However, a small percentage of the irrigation values (agricultural and recreational) for 2005 were obtained from metered data.

Changes.-Some changes in water-use categories have occurred in Florida between 1970 and 2005. Most categories have remained the same since 1970, with some exceptions. During the 1970s, rural water use consisted of domestic self-supplied and livestock. In the 1980s, livestock was added to the agricultural, and domestic self-supplied became a separate category. For many reports, agricultural water use has included all irrigation, but in 1995, golf-course and other recreational irrigation were removed from the agricultural water-use category and placed within a separate category called recreational irrigation. Because water use for golf courses was differentiated for 1985 and 1990, data for recreational irrigation was subtracted from agriculture for those years. Agricultural self-supplied was called irrigation in the 1970s, then became agricultural irrigation in the 1980s with the addition of livestock and removal of recreation irrigation. Commercial-industrial self-supplied was previously called industrial water use, and power generation was previously called thermoelectric power generation.

Miscellaneous water withdrawals and uses included in county totals presented in the 1985 water-use report (Marella, 1988) included water withdrawals for residential lawn irrigation, residential heat pumps and air-conditioning units, and water discharged from free-flowing wells. Because of the inconsistency in data from county to county for these uses, they were not included in the 1985 statewide totals (Marella, 1988). Since 1985, some data on residential lawn watering for several counties have been updated and are included in the recreational irrigation section of this report under turf grass. Water used by residential heat pumps and air-conditioning units and water discharged from free-flowing wells remain inconsistent between counties and are not included in this report.

Data for Miami-Dade County prior to 2000 are reported under Dade County. In 1997, Dade County officially became Miami-Dade County, and all data presented herein is listed under Miami-Dade County. Polk County, which was divided among three WMDs (SJRWMD, SFWMD, and SWFWMD), was redeliniated into two WMDs in 2003, as the part of the county within SJRWMD was officially relinquished to SWFWMD in 2004. Therefore, all data after 2003 for Polk County will reflect totals for SFWMD and SWFWMD only.

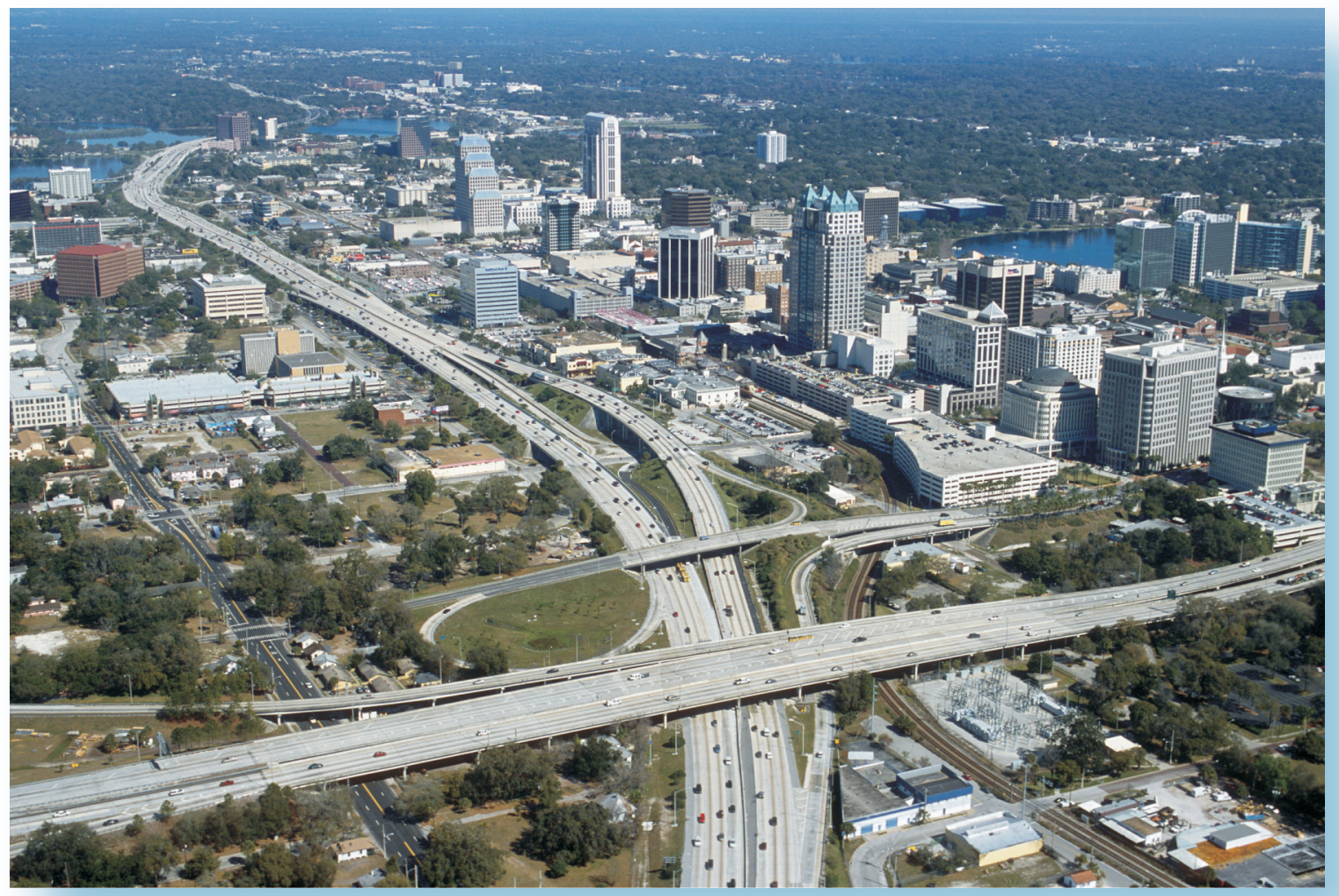

View of downtown Orlando, Florida. Photograph courtesy of the St. Johns River Water Management District. 


\section{Water Withdrawals and Use}

In 2005, the total water withdrawals in Florida was estimated at 18,359 Mgal/d (table 1). Saline water accounted for $11,486 \mathrm{Mgal} / \mathrm{d}$ (63 percent) and freshwater accounted for $6,873 \mathrm{Mgal} / \mathrm{d}$ (37 percent) of total water withdrawals in 2005 (fig. 3). Groundwater accounted for 4,247 Mgal/d (62 percent) of freshwater withdrawals, and surface water accounted for the remaining 2,626 Mgal/d (38 percent). Surface water accounted for nearly all (99.9 percent) saline-water withdrawals (table 1). An additional $660 \mathrm{Mgal} / \mathrm{d}$ of reclaimed wastewater was used in Florida during 2005 (Florida Department of Environmental Protection, 2006). About one-half of the reclaimed wastewater flow in 2005 was used to reduce potable-quality water withdrawals for urban irrigation, agricultural irrigation, and industrial use, but one-third of the reclaimed wastewater was returned to available water supplies as aquifer recharge (Gregory M. Brown, FDEP, written commun., 2008).

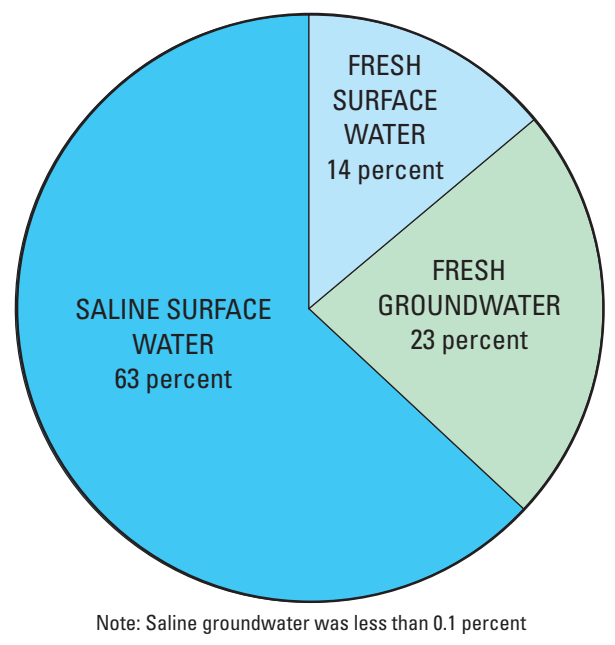

Figure 3. Total water withdrawals in Florida by source, 2005.

Table 1. Total water withdrawals in Florida by category, 2005.

[Source: U.S. Geological Survey, Florida Water Science Center - Tallahassee; all values in million gallons per day]

\begin{tabular}{|c|c|c|c|c|c|c|c|}
\hline \multirow{2}{*}{ Florida 2005} & \multicolumn{3}{|c|}{ Freshwater } & \multicolumn{3}{|c|}{ Saline water } & \multirow{2}{*}{$\begin{array}{c}\text { All water } \\
\text { Total }\end{array}$} \\
\hline & Ground & Surface & Total & Ground & Surface & Total & \\
\hline Public supply & $2,201.26$ & 339.26 & $2,540.52$ & 0.00 & 0.00 & 0.00 & $2,540.52$ \\
\hline Domestic self-supplied & 190.38 & 0.00 & 190.38 & 0.00 & 0.00 & 0.00 & 190.38 \\
\hline Commercial-industrial self-supplied & 365.56 & 122.77 & 488.33 & 0.00 & 1.19 & 1.19 & 489.52 \\
\hline Agricultural self-supplied & $1,301.57$ & $1,464.61$ & $2,766.18$ & 0.00 & 0.00 & 0.00 & $2,766.18$ \\
\hline Recreational irrigation & 171.03 & 158.61 & 329.64 & 0.00 & 0.00 & 0.00 & 329.64 \\
\hline Power generation & 17.56 & 540.52 & 558.08 & 3.26 & $11,481.10$ & $11,484.36$ & $12,042.44$ \\
\hline State totals: & $4,247.36$ & $2,625.77$ & $6,873.13$ & 3.26 & $11,482.29$ & $11,485.55$ & $18,358.68$ \\
\hline
\end{tabular}

The amount of monthly freshwater withdrawals fluctuates because of variations in temperature, precipitation (rainfall), crop production, and tourism. Nearly one-quarter (24 percent) of freshwater withdrawals in 2005 were in April and May (fig. 4). Seasonal variation in withdrawals is typical with more monthly fluctuation occurring in relatively drier years.

Overall, agricultural self-supplied was the largest user of freshwater in 2005, accounting for 40 percent of total freshwater withdrawals, followed by public supply at 37 percent. For fresh groundwater, public supply (52 percent) and agricultural self-supplied (31 percent) were the largest users in 2005, followed by commercial-industrial self-supplied (including mining) (8.5 percent), domestic self-supplied (4 percent), recreational irrigation ( 4 percent), and power generation ( 0.5 percent) (fig. 5 and table 1). For fresh surface water, agricultural self-supplied (56 percent) was the largest user in 2005 , followed by power generation (20.5 percent), public supply (13 percent), recreational irrigation (6 percent), and commercial-industrial self-supplied (4.5 percent) (fig. 5 and table 1). Power generation accounted for nearly all (99.9 percent) saline-water withdrawals.

The largest amount of fresh surface-water withdrawals came from Palm Beach County, and the largest amount of saline surface-water withdrawals came from Pasco County (table 2). Significant withdrawals (more than $200 \mathrm{Mgal} / \mathrm{d}$ ) of fresh groundwater were in Miami-Dade, Palm Beach, Broward, Orange, and Polk Counties. Significant withdrawals (more than $200 \mathrm{Mgal} / \mathrm{d}$ ) of fresh surface water occurred in Palm Beach, Escambia, and Hendry Counties. 


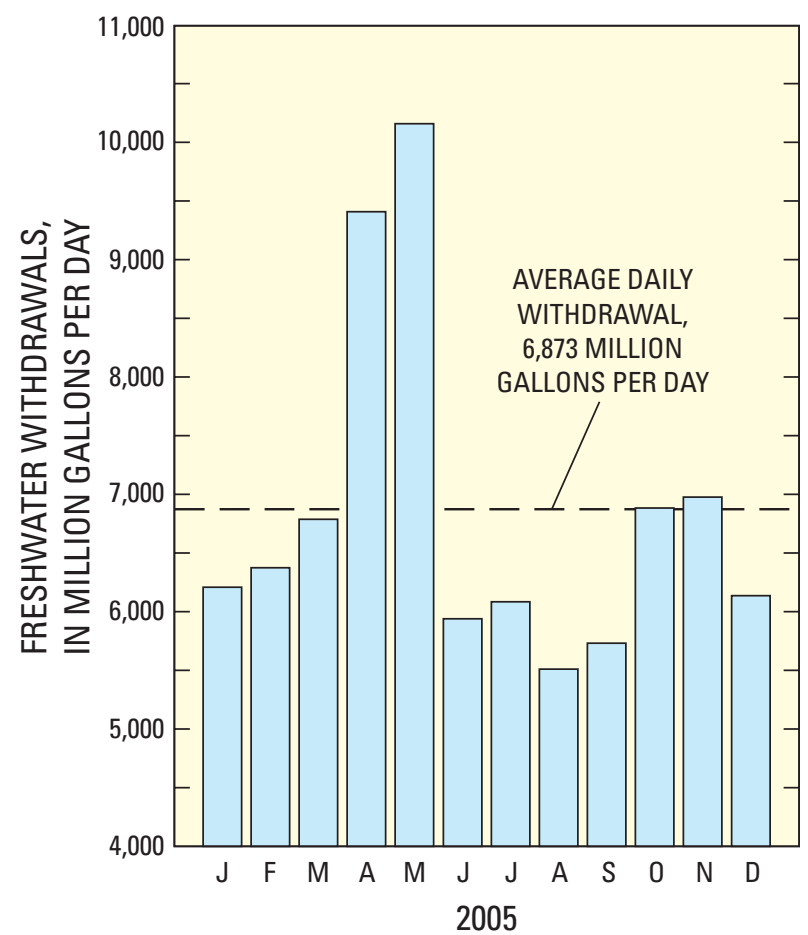

Figure 4. Average daily freshwater withdrawals by month in Florida, 2005.

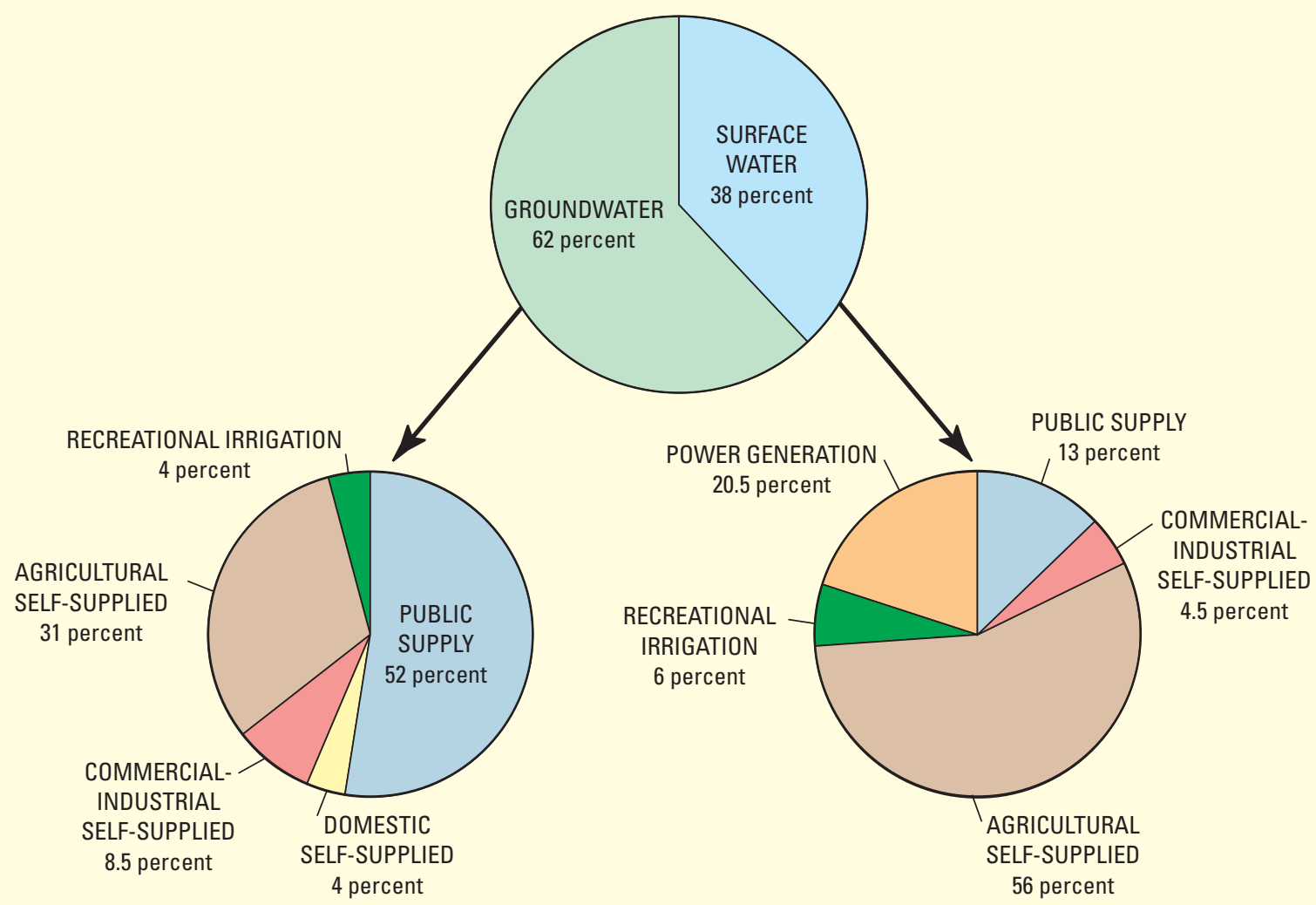

NOTE: Groundwater withdrawals for power generation accounted for about 0.5 percent.

Figure 5. Fresh groundwater and surface-water withdrawals in Florida by category, 2005. 
Table 2. Total water withdrawals in Florida by county, 2005.

[Source: U.S. Geological Survey, Florida Water Science Center - Tallahassee; all values in million gallons per day]






\section{Water Source and Use Category}

Florida is the largest user of groundwater east of the Mississippi River and ranked sixth in the Nation in groundwater withdrawals in 2005 (Kenny and others, 2009). Fresh groundwater withdrawals in 2005 totaled 4,247 Mgal/d and provided drinking water for 16.19 million people (90 percent of Florida's population). Groundwater is available throughout the State, and generally needs little or no treatment prior to use. However, about 5 percent of groundwater is treated or diluted to meet drinking water standards (but is still considered freshwater). About 2,527 Mgal/d (nearly 60 percent) of groundwater withdrawals in 2005 was obtained from the Floridan aquifer system (including $3 \mathrm{Mgal} / \mathrm{d}$ of saline water), which underlies the entire State (fig. 6). Orange and Polk Counties were the largest users of water from the Floridan aquifer system (table 3). The Biscayne aquifer supplied $829 \mathrm{Mgal} / \mathrm{d}$ (19.5 percent) groundwater withdrawals, and the remaining 21 percent was obtained from the surficial aquifer systems (532 Mgal/d), the intermediate aquifer (257 Mgal/d), and the sand-and-gravel aquifer (106 Mgal/d) (fig. 6 and table 3). The sand-and-gravel aquifer is part of the coastal lowlands aquifer system that is present in Alabama, Florida, Louisiana, Mississippi and Texas (Miller, 1990; Renken, 1998). The surficial aquifer systems are primarily used for private household wells or in areas where the Floridan aquifer system is nonpotable or too deep to be used economically.

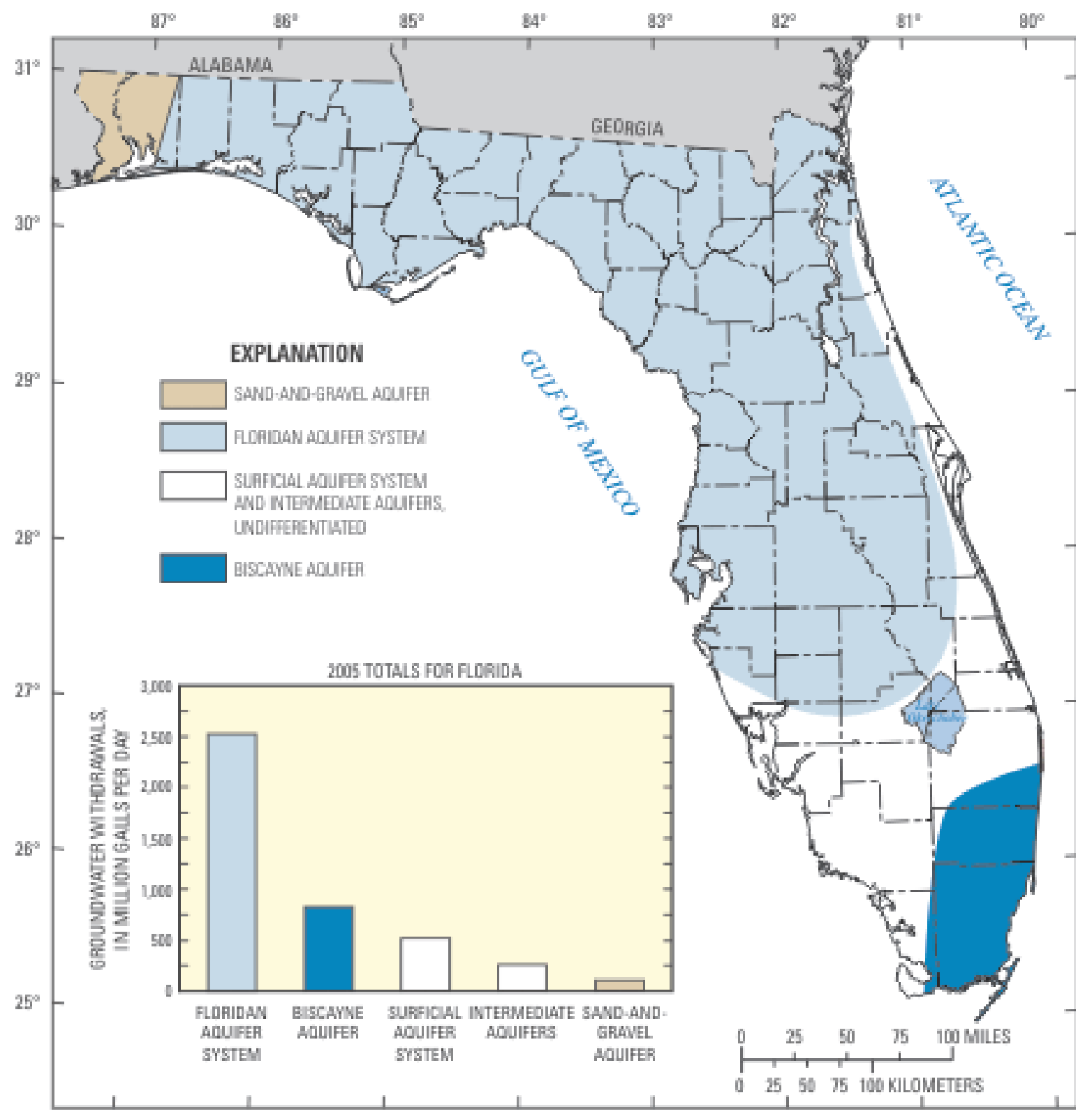

Figure 6. Approximate areal extent throughout which principal aquifers in Florida are the primary source of groundwater, and quantity of groundwater withdrawals, 2005. The sand-and-gravel aquifer is part of the coastal lowlands aquifer system that is present in Alabama, Florida, Louisiana, Mississippi and Texas (Miller, 1990; Renken, 1998). Map modified from Vecchioli and Foose (1985). 
Table 3. Total groundwater withdrawals by principal aquifer in Florida by county, 2005.

[Source: U.S. Geological Survey, Florida Water Science Center - Tallahassee; all values in million gallons per day]

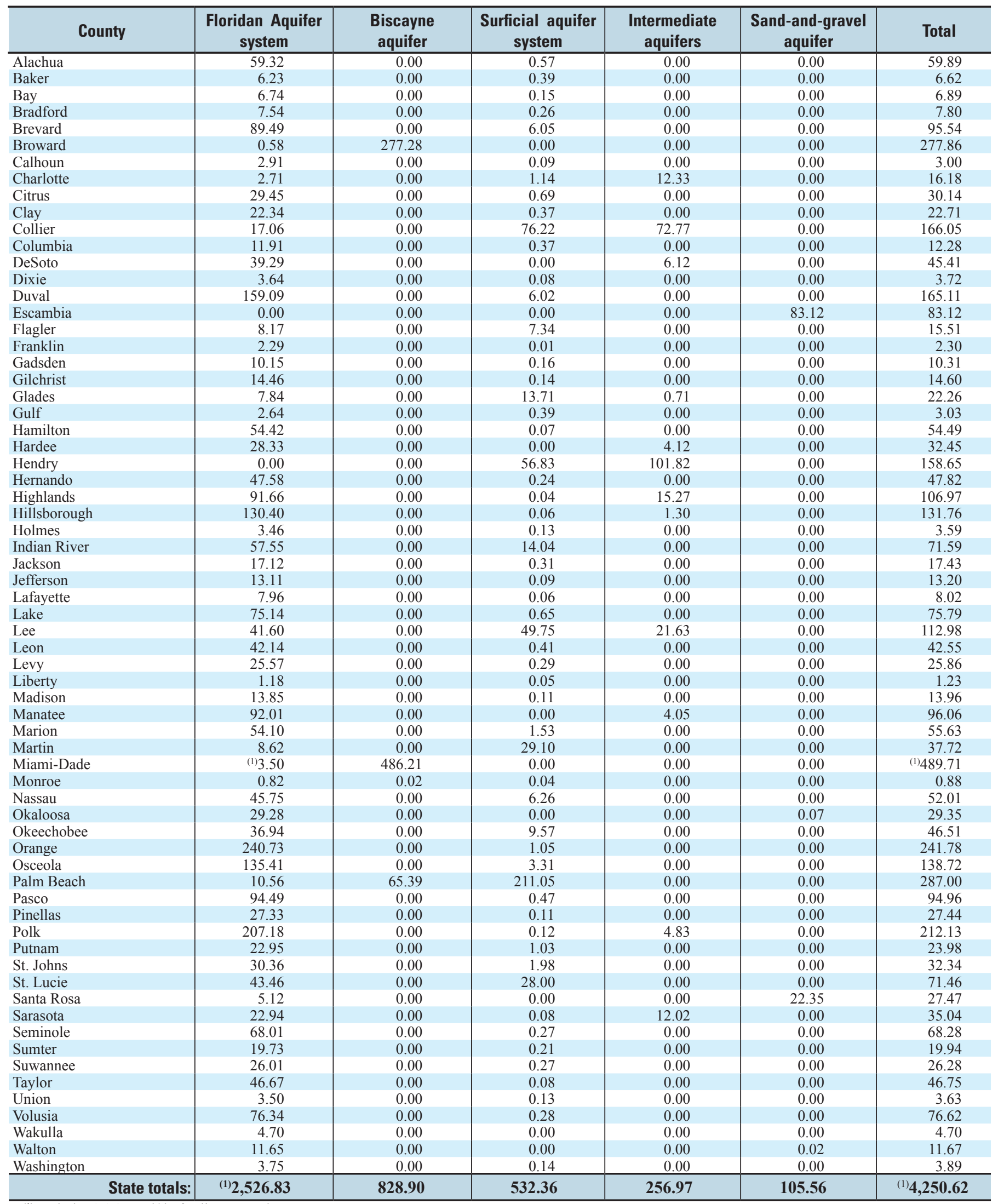

\footnotetext{
(1) Includes $3.26 \mathrm{Mgal} / \mathrm{d}$ of saline groundwater.
} 
Fresh surface-water withdrawals in 2005 totaled 2,626 Mgal/d (table 1) and provided drinking water for 1.73 million people (10 percent of Florida's population). Surface water is available throughout most areas of the State from rivers, lakes, or managed and maintained canal systems. Nearly all fresh surface water in Florida, however, is nonpotable and needs treatment for uses other than irrigation or cooling water. Therefore, the primary use of surface water in Florida is for irrigation and power generation, which used more than three-quarters (76 percent) of the fresh surface water in 2005 (fig. 5). The majority of fresh surface-water withdrawals (59 percent) came from the southern Florida hydrologic unit subregion (fig. 7) and is associated with Lake Okeechobee and the canals in the Everglades Agricultural Area of Glades, Hendry, and Palm Beach Counties as well as the Caloosahatchee River and its tributaries in the agricultural areas of Charlotte, Collier, Glades, Hendry, and Lee Counties. Surface water from these sources is most often diverted through canals or ditches, then pumped or gravityfed onto fields or groves. A large percentage of the water that is flooded onto fields or groves is unused and pumped back into the canals or ditches for further use. Throughout Florida, many of the canals, ditches, or ponds that are used for irrigation are often augmented with groundwater.

Saline surface-water withdrawals in 2005 totaled $11,482 \mathrm{Mgal} / \mathrm{d}$ (table 1 ). With nearly 1,200 miles of coastline and countless coastal rivers and bays (Fernald and Purdum, 1992), saline surface water in Florida is abundant. Nearly all salinewater withdrawals in Florida are for power generation and were used as cooling water that generated about 60 percent of the State's total electric power in 2005. In the future, saline surface water will also be used for public supply and treated through desalination (Tampa Bay Water, 2008).

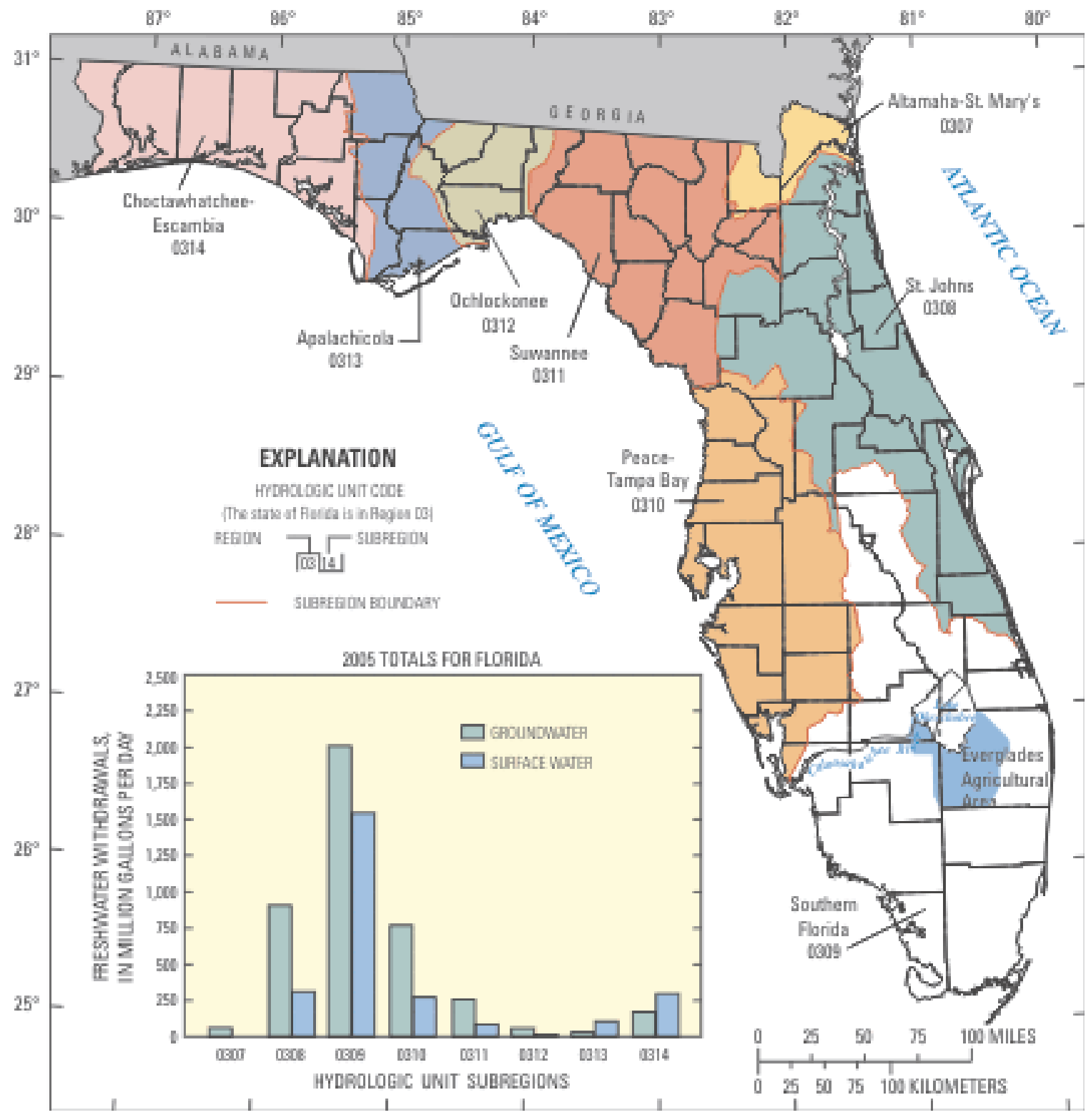

Figure 7. General location of hydrologic units in Florida and fresh groundwater and surface-water withdrawals within these units, 2005. Map from Seaber and others (1984) and U.S. Geological Survey (1975). 


\section{Public Supply}

The public-supply category refers to water distributed by a publicly or privately owned community water system. A total of 1,903 community water systems in Florida met these criteria in 2005 (Edward B. James, FDEP, written commun., 2008). For this report, water-use data were collected for about 1,200 systems that either served 400 people or more, or withdrew 10,000 gal/d (0.01 Mgal/d) or more. Water withdrawals from the inventoried systems totaled 2,541 Mgal/d and accounted for an estimated 99.8 percent of total public-supply withdrawals in 2005 . Water withdrawals by the uninventoried systems were estimated to be about $6 \mathrm{Mgal} / \mathrm{d}$ (703 systems multiplied by $0.009 \mathrm{Mgal} / \mathrm{d}$ ) and would be accounted for under the domestic self-supplied category. These totals do not include noncommunity public-water systems that serve transient populations, such as churches, restaurants, theme parks, and others that provide drinking water to a nonpermanent population.

Water withdrawals for public supply in Florida in 2005 totaled 2,541 Mgal/d (table 4). Groundwater supplied 2,201 Mgal/d (87 percent) and surface water supplied nearly $340 \mathrm{Mgal} / \mathrm{d}$ (13 percent). Nearly 90 percent (16.13 million) of the State's 17.92 million residents obtained their drinking water from a public-supply water system (table 4). Of those 16.13 million residents using public-supply drinking water, 89 percent (14.40 million) were supplied from groundwater sources, and the remaining 11 percent (1.73 million) received water from surface-water sources.

Florida ranked first in the Nation in groundwater withdrawals for public supply (Kenny and others, 2009). The Floridan aquifer system supplied nearly 53 percent of the total public-supply withdrawals (fig. 8) and served an estimated 8.10 million people. The Biscayne aquifer supplied 33 percent of the total public-supply withdrawals and served 4.48 million people.

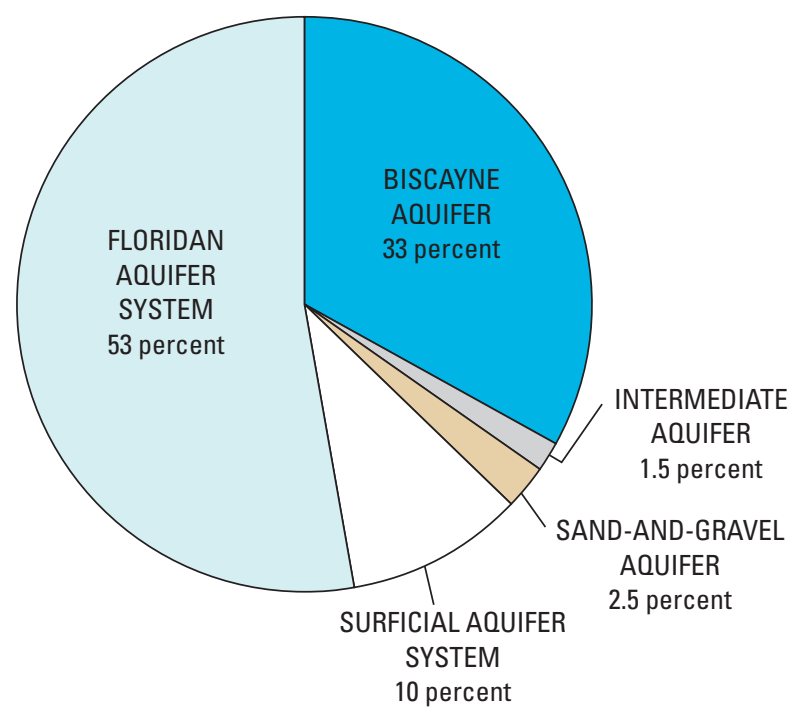

Figure 8. Public-supply groundwater withdrawals in Florida by principal aquifer, 2005.
The Hillsborough River in Hillsborough County supplied 23 percent of the total surface water for public supply, followed by Deer Point Lake in Bay County (13 percent), and Clear Lake in Palm Beach County (9 percent). Other significant surface-water sources of public-supply water include the Braden and Manatee Rivers in Manatee County, Lake Washington in Brevard County, and the Peace River and Shell Creek in Charlotte and De Soto Counties. Some of the public-supply water systems that use surface water also augment their water supply with groundwater from standby wells used during periods of high demands. In addition, several water suppliers inject and store excess fresh surface water that becomes available during the wet season into a deep aquifer, then recover it during the dry season (if needed) to help offset peak demands (Reese, 2006). Values for the amount of water injected into groundwater sources for aquifer storage and recovery (ASR) systems are not included in this report.

Public-supply withdrawals in 2005 were smallest in December and largest in April, May, and September (fig. 9). Seasonal differences in residential demands are caused by variations in temperature, precipitation, and tourism. Variations from climatic conditions cause large demands for lawn water from public-supply water systems, mostly during the drier months. Because precipitation was more normal in 2005 , monthly variation in public-supply water demands was much less than previous years (Marella, 2004; Verdi and others, 2006, table 13).

Public suppliers provide water (deliveries) for domestic (residential), commercial, industrial, public use (including losses), and other uses (see Glossary). Domestic water use,

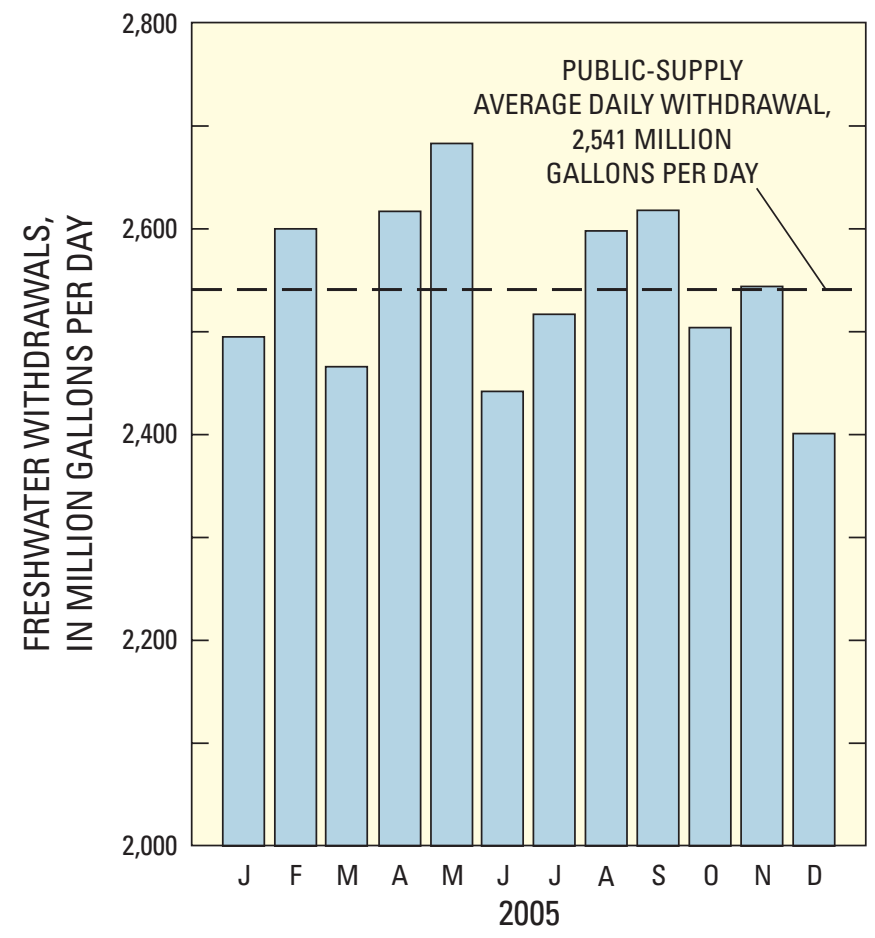

Figure 9. Average daily public-supply freshwater withdrawals by month in Florida, 2005. 
Table 4. Public-supplied population, water use, withdrawals, transfers, and treated water in Florida by county, 2005.

[Source: U.S. Geological Survey; Florida Water Science Center - Tallahassee; water values in million gallons per day]

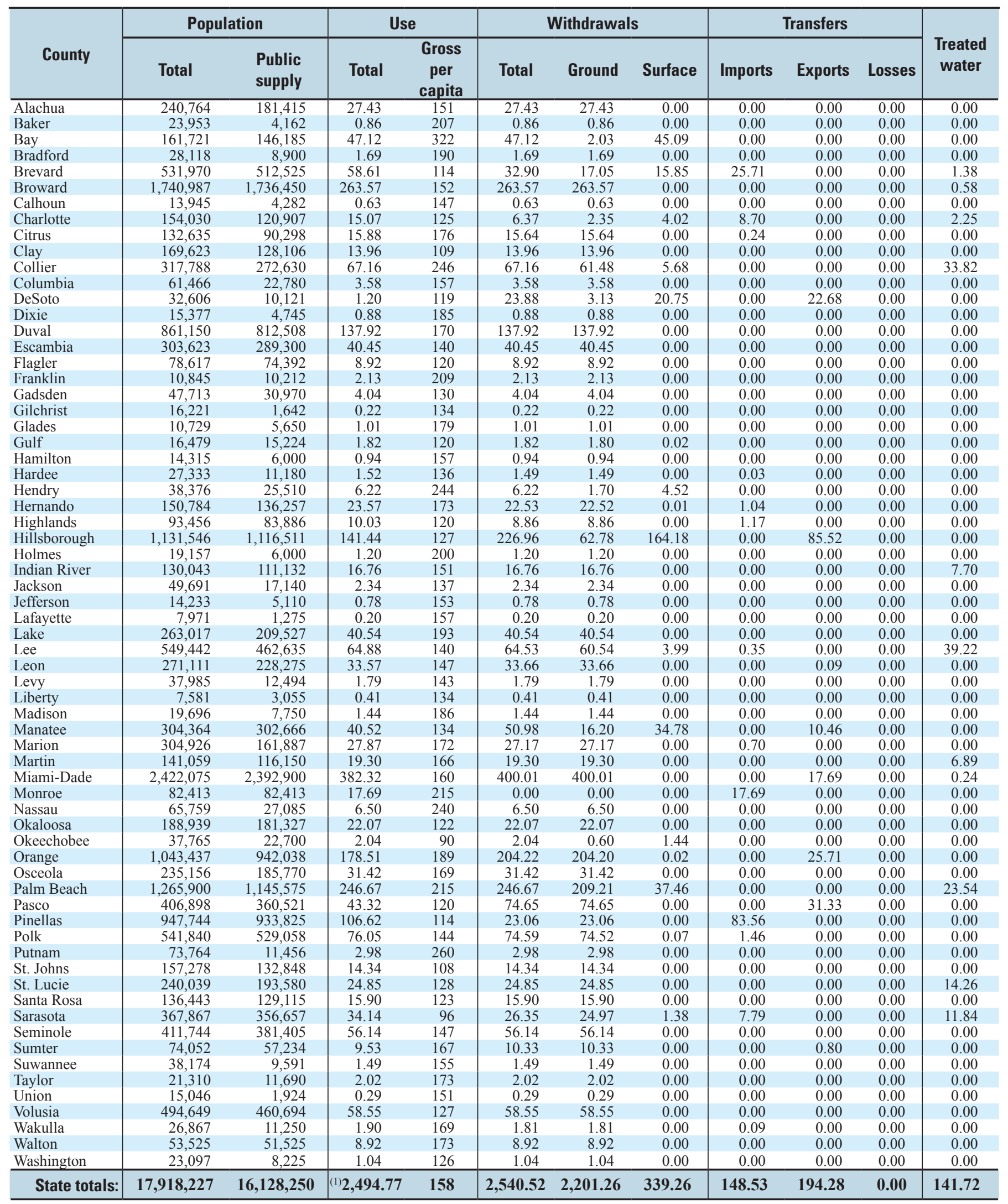

${ }^{(1)}$ Does not include 45.75 million gallons per day that is lost during wholesale transfers. 


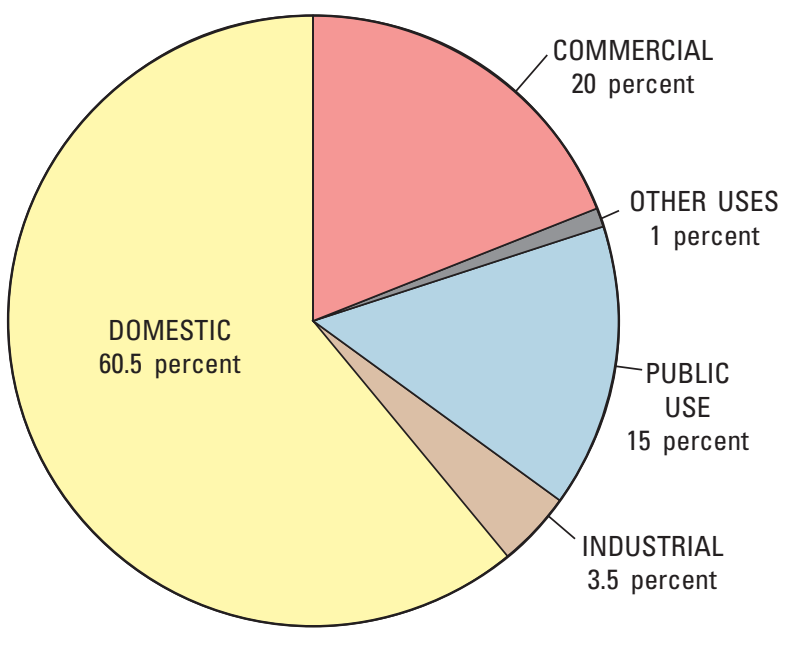

Figure 10. Public-supply water-use deliveries in Florida, 2005.

which includes indoor and outdoor residential uses, accounted for 60.5 percent of the public-supply withdrawals in 2005 (fig. 10 and table 5). Domestic water use was derived from the residual of the total public-supply net water use in each county (withdrawals plus imports or minus exports) minus the commercial, industrial, public use, and other uses. Commercial and industrial water deliveries were estimated by multiplying county employment totals (U.S. Census Bureau, 2006b) by a water-use coefficient based on average water use per employee (Davis and others, 1988) for various commercial and industrial employment sectors (Bucca and Marella, 1992). Deliveries to commercial (20 percent) and industrial (3.5 percent) users in 2005 totaled $591 \mathrm{Mgal} / \mathrm{d}$ (504 Mgal/d for commercial and $87 \mathrm{Mgal} / \mathrm{d}$ for industrial) (fig. 10 and table 5). The public-use category includes water used for firefighting and system maintenance, as well as all losses from processing to distribution. For the southeastern United States, public uses were estimated at 1 percent and losses were estimated at 14 percent by the American Water Works Association (1992). Combined, this category (public uses and losses) totaled $391 \mathrm{Mgal} / \mathrm{d}$ in 2005, or 15 percent of the total public-supply withdrawals (fig. 10 and table 5). Losses include $46 \mathrm{Mgal} / \mathrm{d}$ of wholesale water lost during transmission (as shown in table 4), as well as losses that occur during desalination and lime softening processes. Some specific data for water losses were provided directly from the individual users, estimated from data provided by the WMDs, or obtained from FDEP monthly operating reports. Other uses include deliveries to a host of users not included in commercial or industrial. These deliveries would include direct metered uses for irrigation (for residential, commercial, and recreational), construction, parks, city common areas (including medians), air-conditioning replenishing, power generation, and other deliveries that do not fall within a specific category. This category was estimated at 1 percent by the American Water Works Association (1992). Estimates of the use or deliveries of public-supply water for each county in Florida are presented in table 5.
The statewide public-supply gross per capita water use for Florida was $158 \mathrm{gal} / \mathrm{d}$ in 2005 (table 5). This value is the total public-supply water withdrawals $(2,541 \mathrm{Mgal} / \mathrm{d})$ divided by the total population served by public supply (16.13 million). Per capita water use computed in this manner includes water delivered for all uses of public-supply water, as shown in table 5 (domestic, commercial, industrial, public use and other uses). Florida's average domestic per capita water use for 2005 was estimated at 95 gal/d in 2005 (table 5). This per capita use is calculated by dividing the deliveries to domestic use (1,534 Mgal/d) from public suppliers (table 5) divided by the population served (16.13 million), and excludes all other uses of public-supply water (commercial, industrial, public use, or other uses). It is estimated that between 25 and 75 percent of the water delivered for domestic use of publicsupply water in Florida is for outdoor purposes (primary for lawn watering) during certain times of the year.

Both the public-supply gross per capita water use and the domestic per capita water use have shown a decline since 1980 (fig. 11). This trend can be attributed to the effects of water conservation and restrictions imposed during this period, as well as the use of reclaimed wastewater for lawn irrigation in conjunction with other "Florida-friendly landscape" techniques (http://www.Floridayards.org). The statewide public-supply gross per capita water use of $158 \mathrm{gal} / \mathrm{d}$ for Florida was lower than the 2005 national average of $172 \mathrm{gal} / \mathrm{d}$ and the domestic per capita water use of $95 \mathrm{gal} / \mathrm{d}$ for Florida was slightly lower than the 2005 national average of $99 \mathrm{gal} / \mathrm{d}$ (Kenny and others, 2009). The national average is heavily influenced by the arid western states.

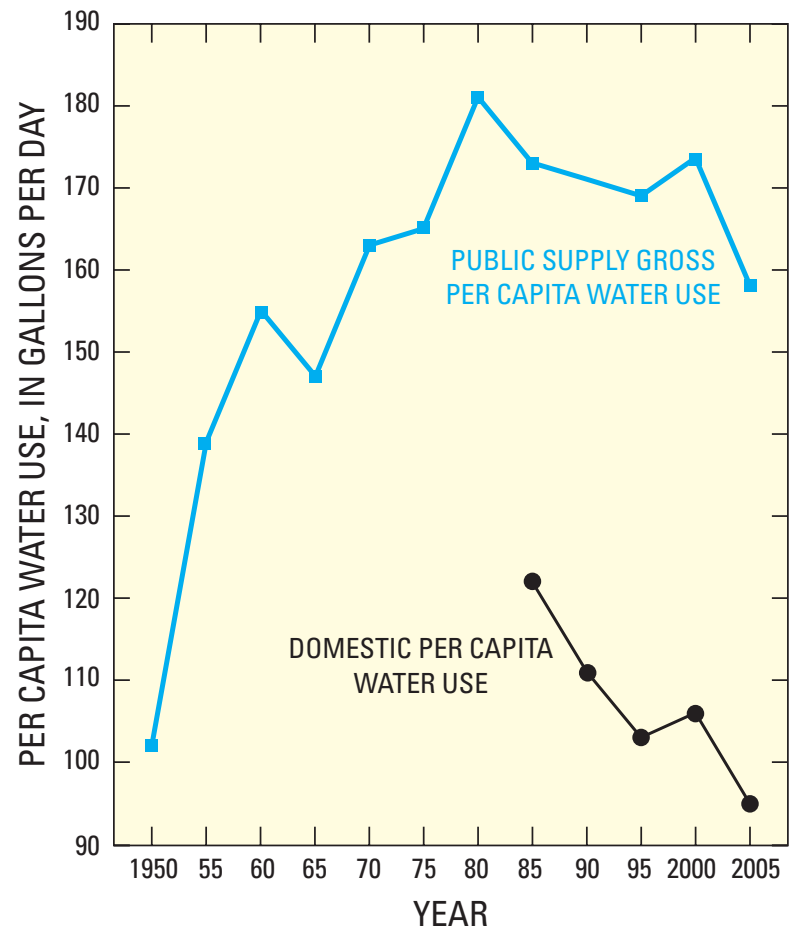

Figure 11. Historical public-supply gross and domestic per capita water use in Florida, 1950-2005. Domestic per capita data was not available prior to 1985. Modified from Marella (2004). 
Table 5. Estimated public-supply water use (deliveries), and per capita use in Florida by county, 2005.

[Source: U.S. Geological Survey; Florida Water Science Center - Tallahassee]

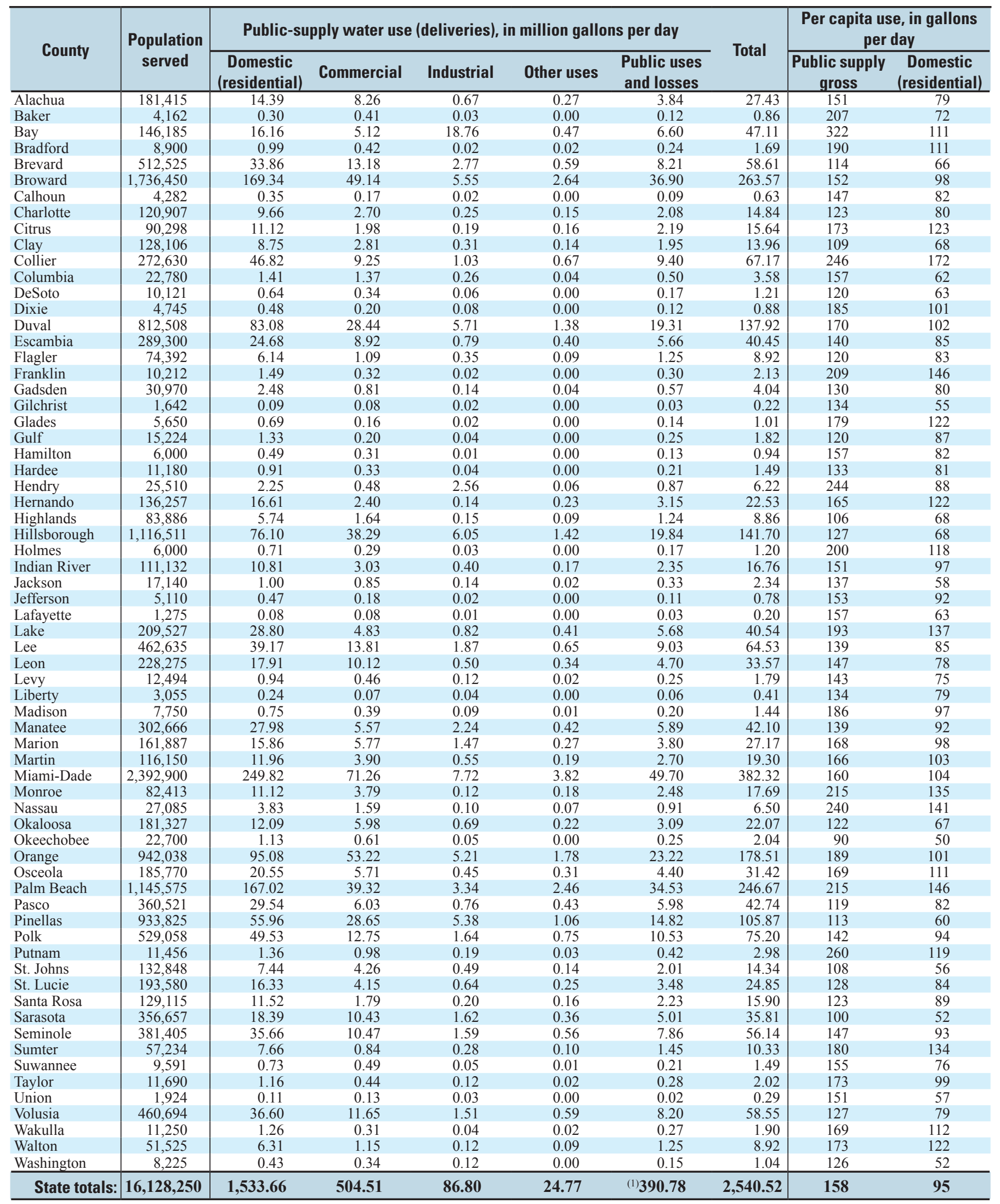

(1) Includes 45.75 million gallons per day of other losses (in transfers or desalination) not assigned to any one county. 
The largest water withdrawals for public supply were in Miami-Dade, Broward, Palm Beach, Hillsborough, and Orange Counties, as each withdrew more than $200 \mathrm{Mgal} / \mathrm{d}$ in 2005 (table 4). Miami-Dade County, Water and Sewer Department (http://www.miamidade.gov/wasd/) is the single largest water supplier in the State, followed by Tampa Bay Water (http://tampabaywater.org/) and Jacksonville Electric Authority (JEA) Water and Sewer (http://www.jea. com/). During 2005, Miami-Dade County, Water and Sewer Department withdrew $346 \mathrm{Mgal} / \mathrm{d}$ of water (Krista Guerrero, SFWMD, written commun., 2007) and served slightly more than 2.0 million people, followed by Tampa Bay Water (168 Mgal/d) and Jacksonville Electric Authority (130 Mgal/d). Miami-Dade Water and Sewer obtained all of its water from the Biscayne aquifer through several large and small well fields within the county. In 2005, Tampa Bay Water obtained 75 percent of its water from multiple well fields that tap the Floridan aquifer system in Hillsborough, Pasco, and Pinellas Counties and 25 percent of its water from surface sources in Hillsborough County (Warren Hogg, Tampa Bay Water, written commun., 2009). A small amount of water withdrawn by Tampa Bay Water in 2005 (less than $1 \mathrm{Mgal} / \mathrm{d}$ ) was obtained from saline surface-water desalination. All of the water withdrawn by Tampa Bay Water is transferred to their six Member Government utilities within Hillsborough, Pasco, and Pinellas Counties as Tampa Bay Water moves water from

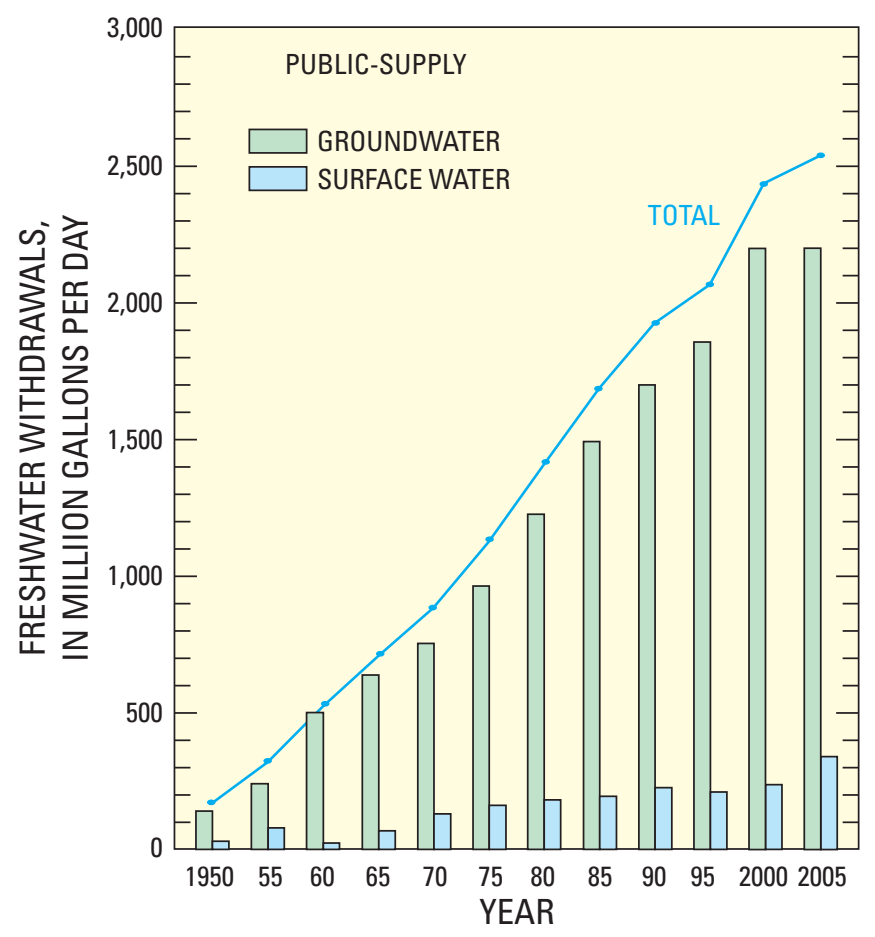

Figure 12. Historical public-supply freshwater withdrawals in Florida by source, 1950-2005. Modified from Marella (2004). withdrawal source to suppliers (table 4). JEA obtained all of its water from wells that tap the Floridan aquifer system in Duval, Nassau, and St. Johns Counties (Bruce Florence, SJRWMD, written commun., 2007). The Florida Keys Aqueduct Authority (FKAA) in Monroe County obtained all of its water $(18 \mathrm{Mgal} / \mathrm{d})$ in 2005 (Krista Guerrero, SFWMD, written commun. 2007) from a well field located in southern MiamiDade County for public-supply use throughout the Florida Keys.

Water withdrawals for public supply in Florida have increased steadily since water-use data were first collected (fig. 12). Total public-supply withdrawals increased 80 percent in the 25 years between 1980 and 2005 and 4 percent in the 5 years between 2000 and 2005. During these same time periods, the population of Florida increased 8.17 million (84 percent) between 1980 and 2005 (U.S. Census Bureau, 2006a), and 1.94 million (12 percent) between 2000 and 2005. In addition to the increase in the State's population, the percentage of the population that relies on public supply for drinking water increased. In 1980, about 80 percent of the State's population was served by a public supplier (Marella, 1993); this percentage increased to 88 percent in 2000 (Marella, 2004), and to 90 percent in 2005. Public-supply withdrawals increased $1,134 \mathrm{Mgal} / \mathrm{d}$ (81 percent) between 1980 and 2005, and $104 \mathrm{Mgal} / \mathrm{d}$ (4 percent) between 2000 and 2005. Public-supply withdrawals for 2000 (2,437 Mgal/d) were higher than normal, as dry conditions in the spring and summer caused higher demands for outdoor uses through these seasons. Deliveries of public-supply water to commercial and industrial users increased from $207 \mathrm{Mgal} / \mathrm{d}$ (Leach, 1983 ) in 1980, to $557 \mathrm{Mgal} / \mathrm{d}$ in 2000 (Marella, 2004), to $591 \mathrm{Mgal} / \mathrm{d}$ in 2005 .

The use of highly mineralized water (referred to as nonpotable or brackish water) for public supply has increased steadily in Florida since 1985 (Dykes and Conlon, 1989; Marella, 1988). In 2005, nearly $142 \mathrm{Mgal} / \mathrm{d}$ (table 4) of nonpotable groundwater was treated using demineralization or desalination techniques (mostly desalination) or was diluted with freshwater to meet FDEP drinking-water standards for potable water (see Glossary). The use of desalination or dilution of nonpotable groundwater for public supply was documented in 11 counties (Brevard, Broward, Charlotte, Collier, Indian River, Lee, Martin, Miami-Dade, Palm Beach, St. Lucie, and Sarasota) (table 4). Values reported as nonpotable in this report are the amount of water withdrawals for the removal of salt through a desalination process (reverse osmosis, electro-dialysis and other membrane treatment methods) or dilution. Nonpotable water withdrawals presented in this report are accounted for as freshwater. Additionally, water withdrawals for public supply are often treated to reduce hardness or remove particulates and other compounds using various methods, such as limesoftening, nanofiltration, or other processes. These amounts are not differentiated in the totals for public supply nor are they included in the nonpotable treated totals. The use of nonpotable groundwater has increased by 50 percent since 2000 , and future use will include the treatment of saline surface water (Tampa Bay Water, 2008). 


\section{Domestic Self-Supplied}

The domestic self-supplied category is made up of users that withdraw small quantities of potable water for drinkingwater purposes without the need for a permit from the WMDs. Domestic self-supplied use includes water withdrawals by individual domestic or private wells that serve a household (in some cases, multiple households) and by the 703 small public-supply systems (with a daily average pumpage of less than $0.01 \mathrm{Mgal} / \mathrm{d}$ ) not inventoried under public supply. For this report, it was assumed that all people not served by the 1,200 inventoried public suppliers are self-supplied. Of the $190 \mathrm{Mgal} / \mathrm{d}$ withdrawn for domestic self-supplied use in 2005 (table 6), an estimated 97 percent (184 Mgal/d) was from domestic wells (sometimes referred to as private wells) and 4 percent ( $6 \mathrm{Mgal} / \mathrm{d}$ ) was from the 703 small public-supply systems that were not inventoried. Withdrawals of more than $10 \mathrm{Mgal} / \mathrm{d}$ for domestic self-supplied use in 2005 occurred in Marion, Palm Beach, Orange, and Putnam Counties (table 6). It is assumed that water withdrawals for this category were derived exclusively from groundwater because of its good quality and its widespread availability across the State. About 63 percent of the domestic self-supplied water was obtained from the Floridan aquifer system (fig. 13); the remaining 37 percent was obtained from more shallow sources of the surficial aquifer system, the Biscayne aquifer, the intermediate aquifer, and the sand-and-gravel aquifer. In many areas of Florida, these shallow aquifers yield sufficient water for domestic purposes, especially in areas where the Floridan aquifer system is relatively deep or has poor water quality. An estimated 1.08 million people obtain their well water from the Floridan aquifer system, and the remaining 0.71 million obtained their well water from the local shallow aquifers.

In 2005, an estimated 1.79 million people in Florida were self-supplied (table 6). Very little data exist across the State on the number of domestic wells in use during 2005 even though the Florida Department of Health, County Health Departments and the WMDs manage programs on the completion and

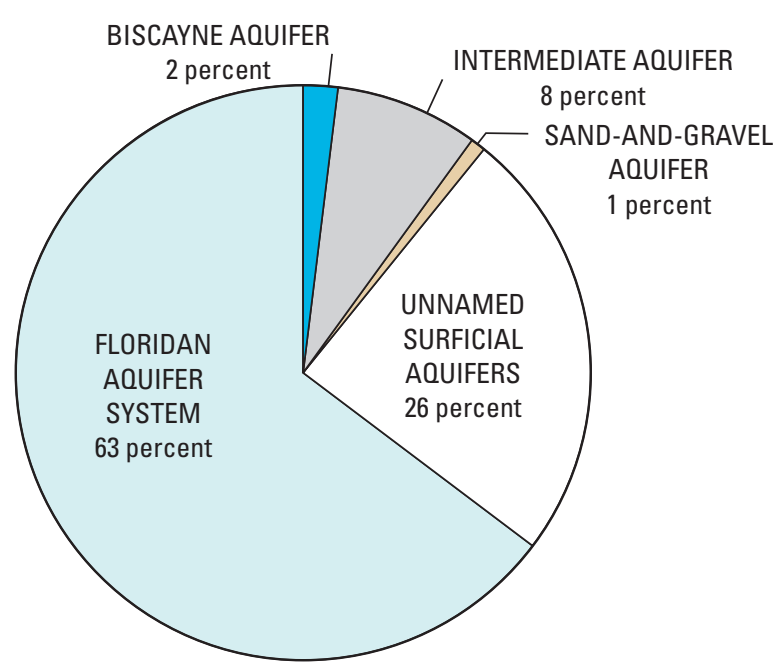

Figure 13. Domestic self-supplied groundwater withdrawals in Florida by principal aquifer, 2005. abandonment of domestic wells. According to the U.S. Census Bureau (1993), 795,560 households in Florida used an individual well as their primary source of drinking water in 1990; however, the census did not compile these data for 2000 or 2005 . Because the population served by public supply is growing at a steady rate, it can be assumed that most new households are connected to public supply, and that many homes that had domestic wells have connected to public-supply water systems during the past 15 years. Large areas of residential development, however, still rely on private wells for drinking water and many of these areas continue to grow. Based on a modest statewide growth rate of 2 percent annually between 2000 and 2005, the number of households with wells is estimated to have increased from 982,500 in 2000 (Marella, 2004) to 1,080,800 in 2005. Estimated water used per well would be about $170 \mathrm{gal} / \mathrm{d}$ in 2005 (184 Mgal/d divided by $1,080,800)$. Many additional households in Florida have private wells for lawn irrigation purposes only, and these withdrawals are not included in this category.

The population that relies on domestic wells has not changed much between 1980 and 2005, remaining at or just below 2 million during this period. Withdrawals for domestic self-supplied use in Florida ranged from slightly below $300 \mathrm{Mgal} / \mathrm{d}$ to slightly below $250 \mathrm{Mgal} / \mathrm{d}$ between 1980 and 2000 (fig. 14). Between the period of 1980 and 2005, two different methods were used to calculate domestic self-supplied withdrawals. In 1980, 1985, 1990, and 1995, the self-supplied population in each county was multiplied by the public-supply gross per capita water use (which ranged between 120 to $250 \mathrm{gal} / \mathrm{d}$ ) for each county to estimate water withdrawals. For 2000 and 2005, the statewide domestic per capita water use was multiplied by the self-supplied population for all counties excluding those within SJRWMD and SWFWMD (these two districts used the public-supply gross per capita value in 2005). The domestic per capita water use in 2000 (106 gal/d) and 2005 (95 gal/d) was derived from public-supply withdrawals minus deliveries

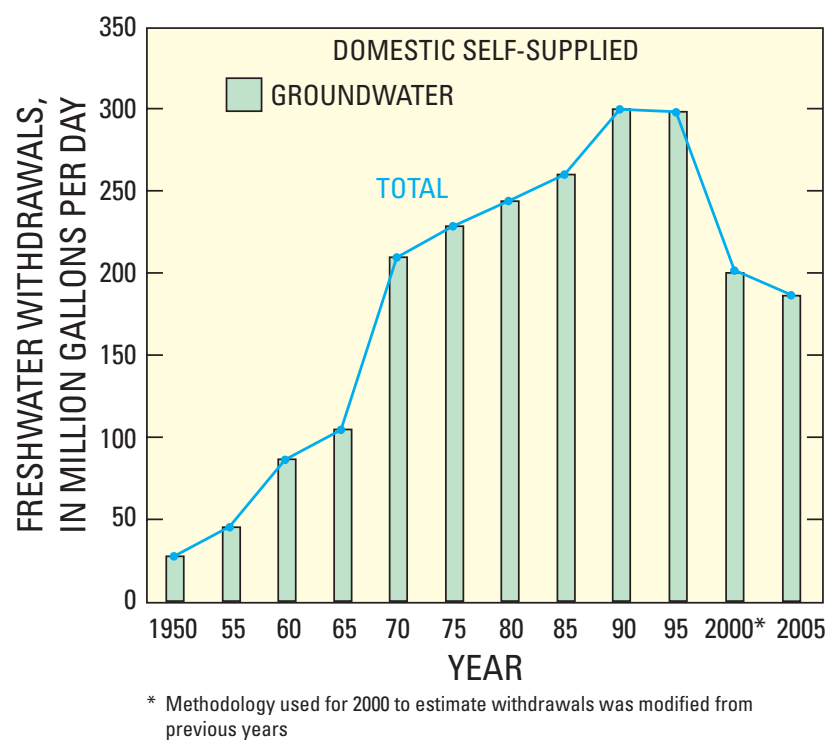

Figure 14. Historical domestic self-supplied freshwater withdrawals in Florida, 1950-2005. Modified from Marella (2004). 
Table 6. Domestic self-supplied population and water withdrawals in Florida by county, 2005.

[Source: U.S. Geological Survey, Florida Water Science Center - Tallahassee; withdrawals in million gallons per day]

\begin{tabular}{|c|c|c|c|c|c|c|}
\hline \multirow{2}{*}{ County } & \multicolumn{3}{|c|}{ Population } & \multicolumn{3}{|c|}{ Water withdrawals } \\
\hline & Total & Public supply & Self-supplied & Ground & Surface & Total \\
\hline Alachua & 240,764 & 181,415 & 59,349 & 5.69 & 0.00 & 5.69 \\
\hline Baker & 23,953 & 4,162 & 19,791 & 3.53 & 0.00 & 3.53 \\
\hline Bay & 161,721 & 146,185 & 15,536 & 1.48 & 0.00 & 1.48 \\
\hline Bradford & 28,118 & 8,900 & 19,218 & 2.62 & 0.00 & 2.62 \\
\hline Brevard & 531,970 & 512,525 & 19,445 & 1.01 & 0.00 & 1.01 \\
\hline Broward & $1,740,987$ & $1,736,450$ & 4,537 & 0.43 & 0.00 & 0.43 \\
\hline Calhoun & 13,945 & 4,282 & 9,663 & 0.92 & 0.00 & 0.92 \\
\hline Charlotte & 154,030 & 120,907 & 33,123 & 3.09 & 0.00 & 3.09 \\
\hline Citrus & 132,635 & 90,298 & 42,337 & 6.89 & 0.00 & 6.89 \\
\hline Clay & 169,623 & 128,106 & 41,517 & 3.57 & 0.00 & 3.57 \\
\hline Collier & 317,788 & 272,630 & 45,158 & 4.30 & 0.00 & 4.30 \\
\hline Columbia & 61,466 & 22,780 & 38,686 & 3.69 & 0.00 & 3.69 \\
\hline DeSoto & 32,606 & 10,121 & 22,485 & 2.09 & 0.00 & 2.09 \\
\hline Dixie & 15,377 & 4,745 & 10,632 & 1.01 & 0.00 & 1.01 \\
\hline Duval & 861,150 & 812,508 & 48,642 & 7.54 & 0.00 & 7.54 \\
\hline Escambia & 303,623 & 289,300 & 14,323 & 1.36 & 0.00 & 1.36 \\
\hline Flagler & 78,617 & 74,392 & 4,225 & 0.29 & 0.00 & 0.29 \\
\hline Franklin & 10,845 & 10,212 & 633 & 0.06 & 0.00 & 0.06 \\
\hline Gadsden & 47,713 & 30,970 & 16,743 & 1.60 & 0.00 & 1.60 \\
\hline Gilchrist & 16,221 & 1,642 & 14,579 & 1.39 & 0.00 & 1.39 \\
\hline Glades & 10,729 & 5,650 & 5,079 & 0.48 & 0.00 & 0.48 \\
\hline Gulf & 16,479 & 15,224 & 1,255 & 0.12 & 0.00 & 0.12 \\
\hline Hamilton & 14,315 & 6,000 & 8,315 & 0.79 & 0.00 & 0.79 \\
\hline Hardee & 27,333 & 11,180 & 16,153 & 1.60 & 0.00 & 1.60 \\
\hline Hendry & 38,376 & 25,510 & 12,866 & 1.23 & 0.00 & 1.23 \\
\hline Hernando & 150,784 & 136,257 & 14,527 & 2.38 & 0.00 & 2.38 \\
\hline Highlands & 93,456 & 83,886 & 9,570 & 0.79 & 0.00 & 0.79 \\
\hline Hillsborough & $1,131,546$ & $1,116,511$ & 15,035 & 1.18 & 0.00 & 1.18 \\
\hline Holmes & 19,157 & 6,000 & 13,157 & 1.25 & 0.00 & 1.25 \\
\hline Indian River & 130,043 & 111,132 & 18,911 & 1.68 & 0.00 & 1.68 \\
\hline Jackson & 49,691 & 17,140 & 32,551 & 3.10 & 0.00 & 3.10 \\
\hline Jefferson & 14,233 & 5,110 & 9,123 & 0.87 & 0.00 & 0.87 \\
\hline Lafayette & 7,971 & 1,275 & 6,696 & 0.64 & 0.00 & 0.64 \\
\hline Lake & 263,017 & 209,527 & 53,490 & 6.49 & 0.00 & 6.49 \\
\hline Lee & 549,442 & 462,635 & 86,807 & 8.27 & 0.00 & 8.27 \\
\hline Leon & 271,111 & 228,275 & 42,836 & 4.08 & 0.00 & 4.08 \\
\hline Levy & 37,985 & 12,494 & 25,491 & 2.85 & 0.00 & 2.85 \\
\hline Liberty & 7,581 & 3,055 & 4,526 & 0.43 & 0.00 & 0.43 \\
\hline Madison & 19,696 & 7,750 & 11,946 & 1.14 & 0.00 & 1.14 \\
\hline Manatee & 304,364 & 302,666 & 1,698 & 0.16 & 0.00 & 0.16 \\
\hline Marion & 304,926 & 161,887 & 143,039 & 15.34 & 0.00 & 15.34 \\
\hline Martin & 141,059 & 116,150 & 24,909 & 2.37 & 0.00 & 2.37 \\
\hline Miami-Dade & $2,422,075$ & $2,392,900$ & 29,175 & 2.78 & 0.00 & 2.78 \\
\hline Monroe & 82,413 & 82,413 & 0 & 0.00 & 0.00 & 0.00 \\
\hline Nassau & 65,759 & 27,085 & 38,674 & 8.20 & 0.00 & 8.20 \\
\hline Okaloosa & 188,939 & 181,327 & 7,612 & 0.73 & 0.00 & 0.73 \\
\hline Okeechobee & 37,765 & 22,700 & 15,065 & 1.44 & 0.00 & 1.44 \\
\hline Orange & $1,043,437$ & 942,038 & 101,399 & 10.55 & 0.00 & 10.55 \\
\hline Osceola & 235,156 & 185,770 & 49,386 & 4.72 & 0.00 & 4.72 \\
\hline Palm Beach & $1,265,900$ & $1,145,575$ & 120,325 & 11.47 & 0.00 & 11.47 \\
\hline Pasco & 406,898 & 360,521 & 46,377 & 4.75 & 0.00 & 4.75 \\
\hline Pinellas & 947,744 & 933,825 & 13,919 & 1.09 & 0.00 & 1.09 \\
\hline Polk & 541,840 & 529,058 & 12,782 & 1.22 & 0.00 & 1.22 \\
\hline Putnam & 73,764 & 11,456 & 62,308 & 10.34 & 0.00 & 10.34 \\
\hline St. Johns & 157,278 & 132,848 & 24,430 & 2.05 & 0.00 & 2.05 \\
\hline St. Lucie & 240,039 & 193,580 & 46,459 & 4.43 & 0.00 & 4.43 \\
\hline Santa Rosa & 136,443 & 129,115 & 7,328 & 0.44 & 0.00 & 0.44 \\
\hline Sarasota & 367,867 & 356,657 & 11,210 & 0.81 & 0.00 & 0.81 \\
\hline Seminole & 411,744 & 381,405 & 30,339 & 2.70 & 0.00 & 2.70 \\
\hline Sumter & 74,052 & 57,234 & 16,818 & 2.12 & 0.00 & 2.12 \\
\hline Suwannee & 38,174 & 9,591 & 28,583 & 2.72 & 0.00 & 2.72 \\
\hline Taylor & 21,310 & 11,690 & 9,620 & 0.92 & 0.00 & 0.92 \\
\hline Union & 15,046 & 1,924 & 13,122 & 1.25 & 0.00 & 1.25 \\
\hline Volusia & 494,649 & 460,694 & 33,955 & 2.75 & 0.00 & 2.75 \\
\hline Wakulla & 26,867 & 11,250 & 15,617 & 1.49 & 0.00 & 1.49 \\
\hline Walton & 53,525 & 51,525 & 2,000 & 0.19 & 0.00 & 0.19 \\
\hline Washington & 23,097 & 8,225 & 14,872 & 1.42 & 0.00 & 1.42 \\
\hline State totals: & 17,918,227 & $16,128,250$ & $1,789,957$ & 190.38 & 0.00 & 190.38 \\
\hline
\end{tabular}


to commercial, industrial, public use, and other users (data for 2005 is shown in table 5). The methodology was changed because the public-supply gross per capita accounted for commercial, industrial, and public use (including losses) and other uses (table 5), thus tending to overestimate the water withdrawals for this category. The domestic per capita water use includes only what is used for households (including both indoor and outdoor uses) and, therefore, provides a better estimate of water withdrawals for this category.

\section{Commercial-Industrial Self-Supplied}

Commercial-industrial self-supplied use refers to water withdrawn directly from commercial and industrial facilities. Commercial users include government and military facilities, schools, prisons, hospitals, recreational (nonirrigation), and nonmanufacturing facilities. Industrial users include mining, processing, and manufacturing facilities. Data were obtained for those systems having withdrawals of more than $0.01 \mathrm{Mgal} / \mathrm{d}$; water used by the smaller commercial-industrial (noncommunity and nontransient noncommunity) water systems is insignificant and, therefore, is not accounted for in this report. A total of 206 self-supplied commercial users and 205 self-supplied industrial users were inventoried in Florida in 2005.

Freshwater withdrawals by the 411 commercial-industrial self-supplied systems in 2005 totaled $488 \mathrm{Mgal} / \mathrm{d}$ (table 7). Groundwater supplied $366 \mathrm{Mgal} / \mathrm{d}$ (75 percent) and surface water supplied more than $122 \mathrm{Mgal} / \mathrm{d}$ (25 percent) of freshwater withdrawals in 2005 (table 7). In addition, another $591 \mathrm{Mgal} / \mathrm{d}$ was delivered to commercial (504 Mgal/d) and industrial ( $87 \mathrm{Mgal} / \mathrm{d}$ ) users from public-supply water systems in 2005 (table 5). The Floridan aquifer system supplied 78 percent of groundwater withdrawals for this category (fig. 15). Major surface-water sources for commercial-industrial self-supplied use include Etonia and Simms Creeks in Putnam County (20 percent) and the Escambia River in Escambia County (19.5 percent). However, a large amount of surface-water withdrawals used for this category came from unnamed mining pits or ponds for dewatering and mining operations. A small amount (1 Mgal/d) of saline surface water was withdrawn from Nassau County for industrial cooling purposes in 2005 (table 7). The largest amount of freshwater withdrawals for commercial-industrial self-supplied purposes was from Polk County, followed by Escambia, Taylor, Miami-Dade, and Nassau Counties (table 7). These five counties accounted for more than one-half (52 percent) of the water withdrawals in this category during 2005.

Monthly withdrawals for commercial-industrial self-supplied fluctuated less than $100 \mathrm{Mgal} / \mathrm{d}$ during 2005 (fig. 16). Withdrawals were highest in July, October, and December and were lowest in November. Fluctuations in withdrawals occur because of increased water demand when citrus and vegetables are harvested and processed, whereas withdrawals for mining and pulp and paper manufacturing usually remain fairly steady throughout the year.

Mining accounted for the largest amount of water used in this category ( 40 percent) followed by pulp and paper manufacturing (28 percent) (fig. 17). Water withdrawals from the

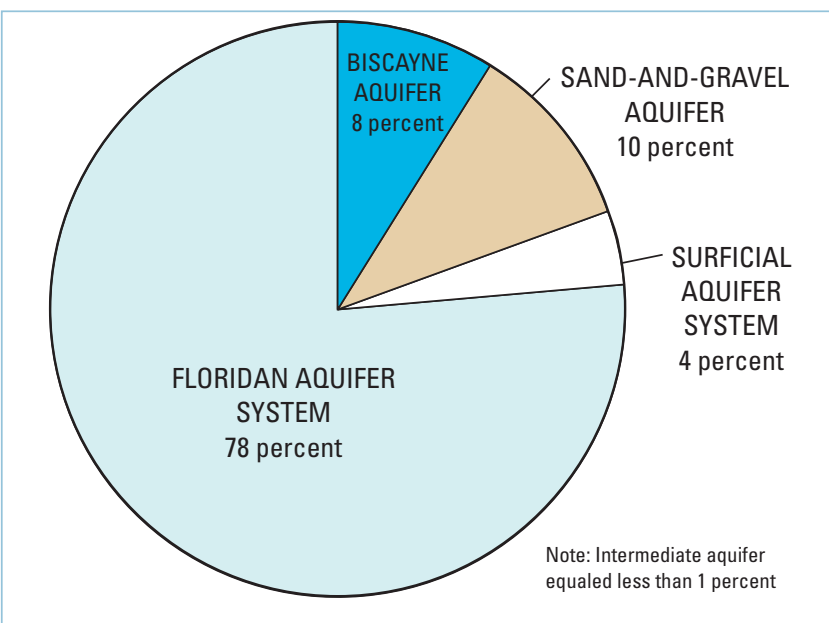

Figure 15. Commercial-industrial self-supplied groundwater withdrawals in Florida by principal aquifer, 2005.

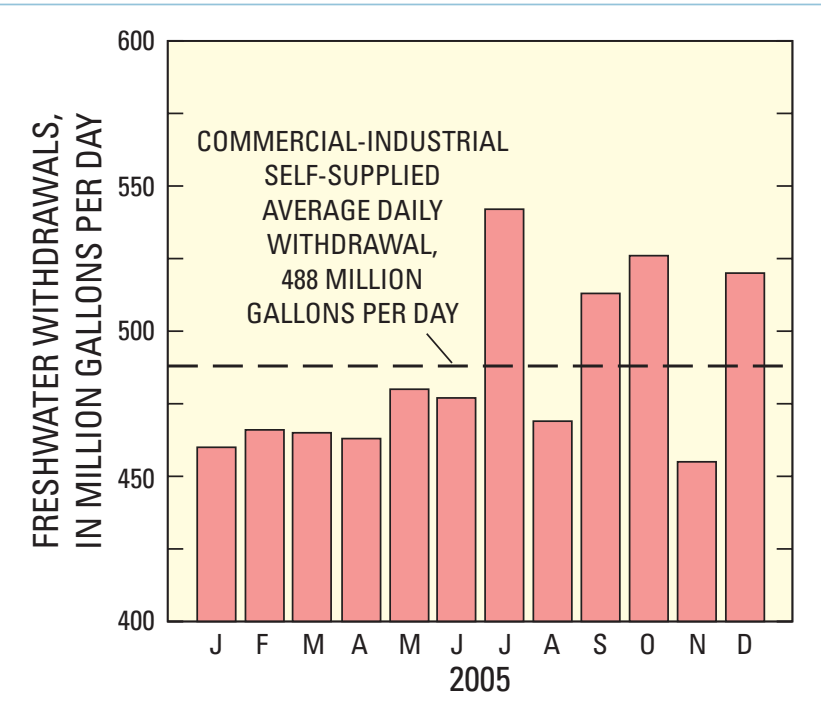

Figure 16. Average daily commercial-industrial self-supplied freshwater withdrawals by month in Florida, 2005.

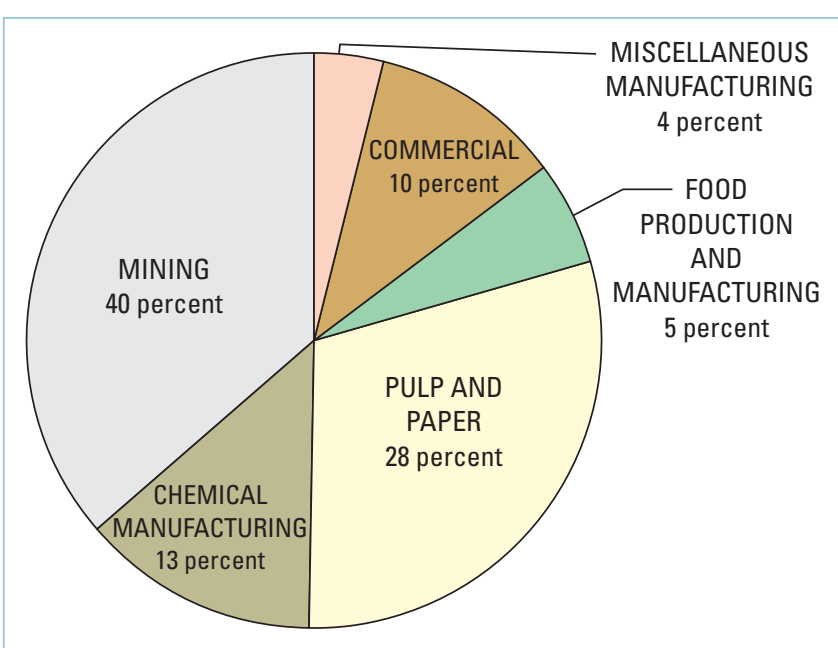

Figure 17. Commercial-industrial self-supplied freshwater use in Florida by major industrial type, 2005. 
Table 7. Commercial-industrial self-supplied (includes mining) water withdrawals in Florida by county, 2005.

[Source: U.S. Geological Survey, Florida Water Science Center - Tallahassee; all values in million gallons per day]

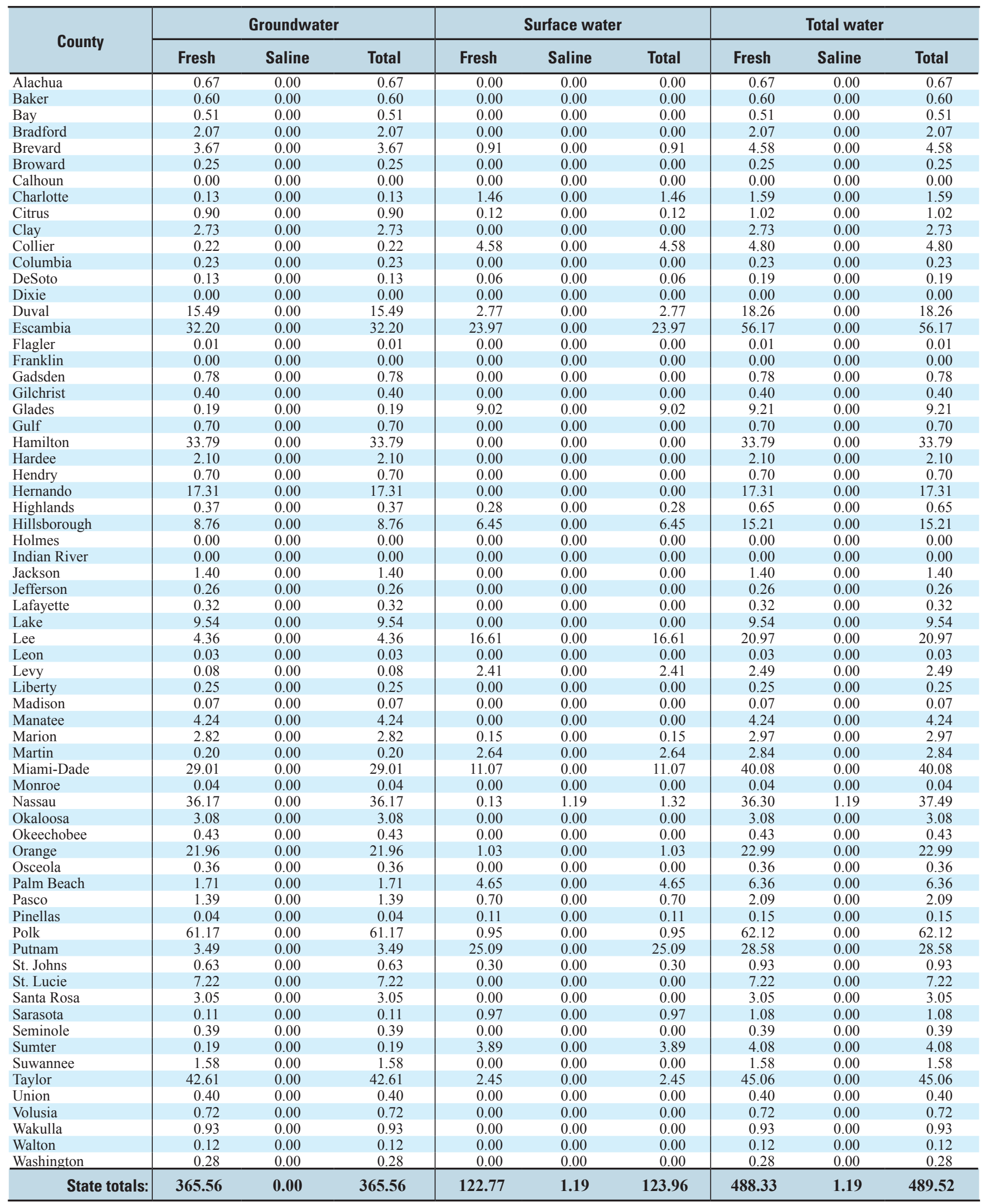


70 inventoried mining facilities totaled $194 \mathrm{Mgal} / \mathrm{d}$, of which 60 percent (117 Mgal/d) was for mining limestone and sand, 36 percent ( $69 \mathrm{Mgal} / \mathrm{d}$ ) for phosphate mining, and 4 percent ( $8 \mathrm{Mgal} / \mathrm{d}$ ) for mineral and other mining. Mining operations are located throughout Florida, but are mostly concentrated in the central and extreme southeastern and southwestern parts of the State. Water withdrawals from the mining industry are used primarily for material washing and conveyance, but includes water pumped to dewater the area being mined. The pulp and paper industry is located in northern and western Florida where the State is heavily forested. Food production accounted for $27 \mathrm{Mgal} / \mathrm{d}$ (5 percent) in 2005, of which about 4 $\mathrm{Mgal} / \mathrm{d}$ was withdrawn for water-bottling purposes. Many of the water-bottling facilities in Florida obtain their water from a public-water supply system. Water withdrawals from the 206 self-supplied commercial users, such as hospitals, prisons, schools, and theme parks accounted for $51 \mathrm{Mgal} / \mathrm{d}$ (10 percent) of the withdrawals in this category (fig. 17). Most of these self-supplied commercial users are considered noncommunity public-supply water system, because they serve a transient, not a permanent, population (Florida Department of Environmental Regulation, 1990).

By 2005, freshwater withdrawals for commercial-industrial self-supplied use in Florida decreased 37 percent from 1990 and 18 percent from 2000 (fig. 18). Between 1990 and 2000, manufacturing employment decreased statewide from 520,000 to 486,000 people (Kathie Hughes, Florida Agency for Workforce Innovation, Labor Market Statistics Center, written commun., 2008) using the Standard Industrial Classification System data. Between 2001 and 2005, manufacturing employment decreased another 30,000 people based on data from the North American Industrial Classification System (Kathie Hughes, Florida Agency for Workforce Innovation, Labor Market Statistics Center, written commun., 2008). Several large chemical plants, pulp mills, and other manufacturing facilities in Florida have closed over the past 15 years. This trend of decreasing manufacturing employment is expected to continue in Florida. However, deliveries from public supply to commercial and industrial users increased by $126 \mathrm{Mgal} / \mathrm{d}$ (27 percent) between 1990 and 2005 and by $33 \mathrm{Mgal} / \mathrm{d}$ (6 percent) between 2000 and 2005. The increase in deliveries and the decrease in self-supplied withdrawals is a result of new commercial or industrial users obtaining their water from a public-supply water system and some self-supplied users connecting to a public-supply water system as their water source. The conversion to public supply in many areas occurred because of the increasing cost for self-supplied users to produce, treat, and discharge their own water. Also, many self-supplied users have become more water efficient over the past 15 years.

\section{Agricultural Self-Supplied (Irrigation and Nonirrigation)}

Agricultural self-supplied use refers to water withdrawals for crop irrigation and for nonirrigation uses associated with farming operations. Crop irrigation includes the application of water on lands to assist in the growing of crops or to prevent

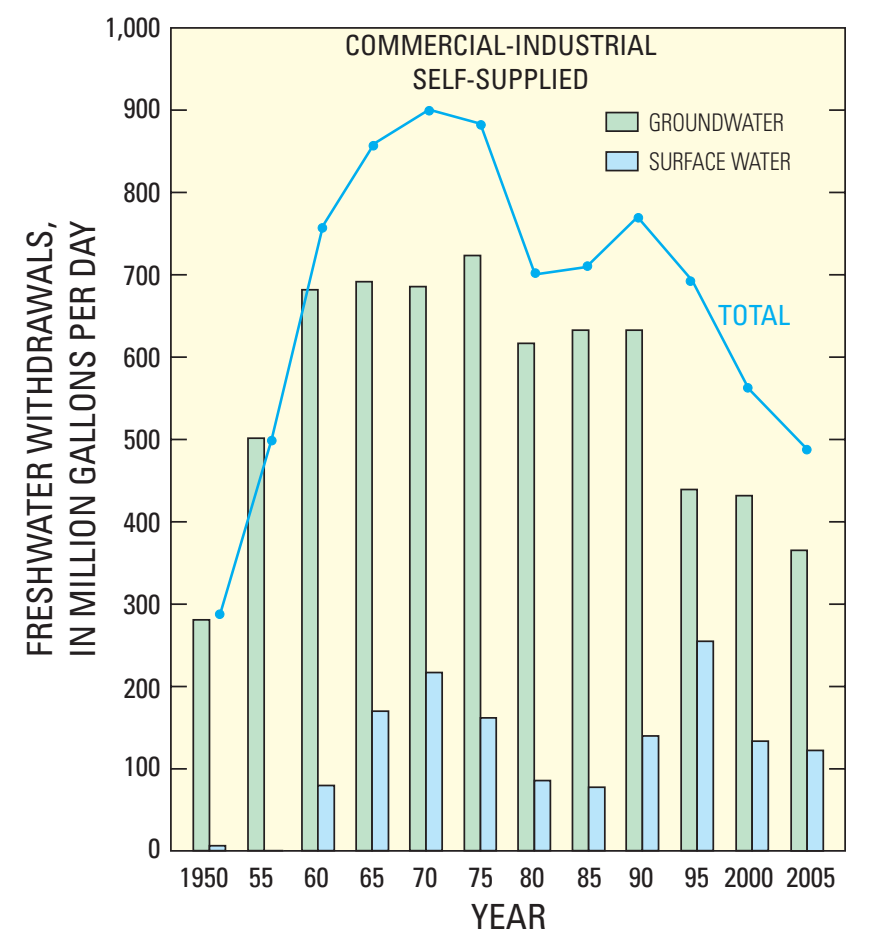

Figure 18. Historical commercial-industrial self-supplied freshwater withdrawals in Florida by source, 1950-2005. Modified from Marella (2004).

damage to crops due to harsh climatic conditions. Nonirrigation uses include withdrawals for livestock watering, washing of dairy and farm equipment, fish farming (augmenting ponds), and other farm uses. The agricultural self-supplied category no longer includes water withdrawals for irrigation of turf grasses (golf courses and urban landscape), which is included in the category of recreational irrigation.

Agricultural self-supplied was the largest user of freshwater in Florida, accounting for 40 percent of the State's total freshwater withdrawals in 2005 . Water withdrawals for agricultural selfsupplied totaled 2,766 Mgal/d (table 8). Surface water supplied 53 percent $(1,465 \mathrm{Mgal} / \mathrm{d})$ and groundwater supplied 47 percent (1,301 Mgal/d) (table 8). All water withdrawals for irrigation in Florida were assumed to be freshwater. Overall, water used for crop irrigation accounted for 99 percent of the water withdrawn in this category with the nonirrigation uses (livestock and fish farming) accounting for the remaining 1 percent.

The Floridan aquifer system supplied 65 percent of the groundwater withdrawn for agricultural self-supplied use in 2005 (fig. 19). The remaining 35 percent was obtained from more shallow sources, such as the Biscayne aquifer, the intermediate aquifer, and the sand-and-gravel aquifer where the Floridan aquifer system does not have good water quality. Major sources of surface water for irrigation purposes include the canals associated with the Caloosahatchee River, the St. Johns River, Lake Okeechobee, and the many unnamed canals in Glades, Hendry, Indian River, Martin, Palm Beach 
Table 8. Agricultural self-supplied water withdrawals in Florida by county, 2005.

[Source: U.S. Geological Survey, Florida Water Science Center - Tallahassee; all values in million gallons per day]

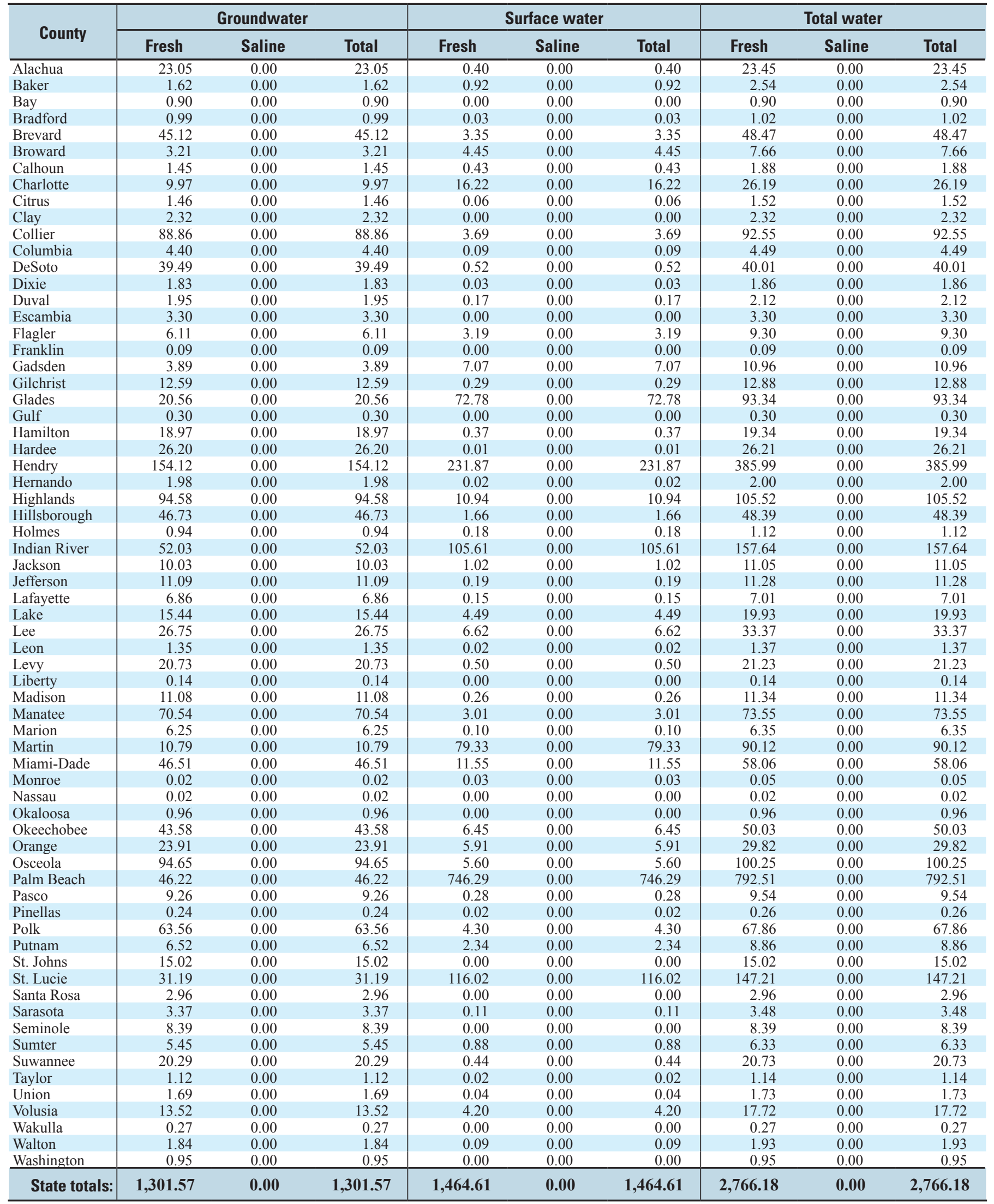


and St. Lucie Counties. South Florida is intensively irrigated for sugarcane, citrus, and vegetables, and these six counties accounted for 92 percent of the surface-water withdrawals for irrigation (table 8).

Monthly withdrawals for agricultural self-supplied use had the largest seasonal variation of any water-use category. Agricultural self-supplied withdrawals were greatest during April and May (accounting for 33 percent of the water used) and were lowest during June, July, August, and September for 2005 (fig. 20). A seasonal fluctuation of more than 4,300 Mgal/d in 2005 resulted from intense crop production and normal dry conditions during the spring months, as well as a decrease in crop production and the normal rainfall patterns during the summer months. This pattern of seasonal withdrawals is normal, but monthly variation is usually greater during extreme dry years (Marella, 1997; Verdi and others, 2006).

A total of 42,500 commercial farms utilized 10 million acres of land in 2005 (Florida Department of Agriculture and Consumer Services, 2006). An estimated 3.864 million acres of this land was used for agricultural crop production during 2005, with about 1.783 million acres irrigated (46 percent) (Florida Department of Agriculture and Consumer Services, 2006). Improved pasture accounted for about one-half of the agricultural crop acres (48 percent); however, only 6 percent of the improved pasture was irrigated in 2005 (U.S. Department of Agriculture, 2004). Excluding improved pasture acreage, an estimated 2.024 million acres were farmed, with 1.671 million acres ( 82.5 percent) of the nonpasture acreage irrigated. Most of the 1.783 million acres were irrigated by flood systems ( 43 percent), followed by micro systems (38 percent), and sprinkler systems (19 percent) (table 9).

Data for crop irrigation were compiled for the following categories: vegetable, fruit crops, field crops, and ornamentals and grasses (including sod). Acreage totals for many of the individual crops were not available for 2005 because values were not published on a county level beyond 2002 (table 9). Fruit crops (including citrus) and field crops (including sugarcane) were the largest users of water for irrigation, accounting for 74 percent ( 37 percent each) of the agricultural self-supplied water withdrawals in 2005 (fig. 21 and table 9). Specifically, citrus (996 Mgal/d) and sugarcane ( $875 \mathrm{Mgal} / \mathrm{d}$ ) accounted for more than two-thirds (67.6 percent) of total water withdrawals for this category. Estimated citrus acreage in 2005 was 0.734 million acres with nearly 94 percent of the acres irrigated (table 9); sugarcane acreage was 0.403 million acres with nearly 99 percent irrigated.

Palm Beach, Hendry, St. Lucie, and Indian River Counties accounted for more than half (54 percent) of total water withdrawals for agricultural self-supplied use (table 8). Palm Beach County was the largest user of surface water, and Hendry County used the most groundwater. Palm Beach County had nearly 0.372 million acres irrigated, of which 0.297 million acres (80 percent) was sugarcane. Hendry, Polk, St. Lucie, and Indian River Counties had the largest amount of irrigated citrus acreage and, when combined, accounted for 43 percent of the State's irrigated citrus acreage in 2005.

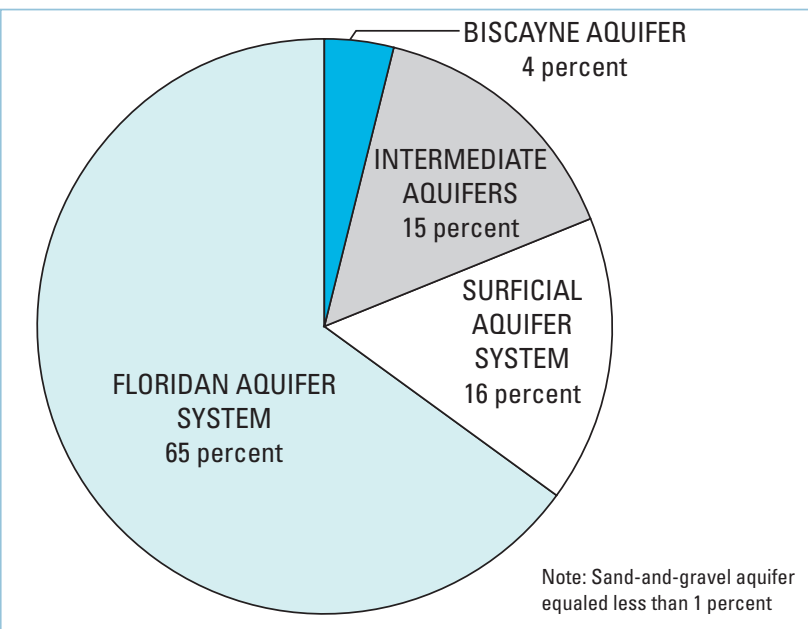

Figure 19. Agricultural self-supplied groundwater withdrawals in Florida by principal aquifer, 2005.

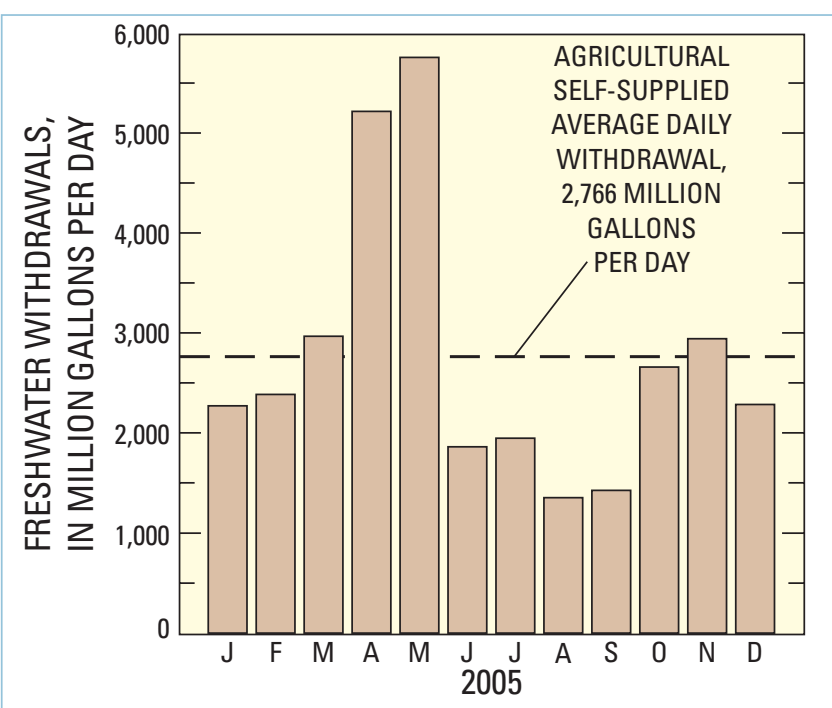

Figure 20. Average daily agricultural self-supplied freshwater withdrawals by month in Florida, 2005.

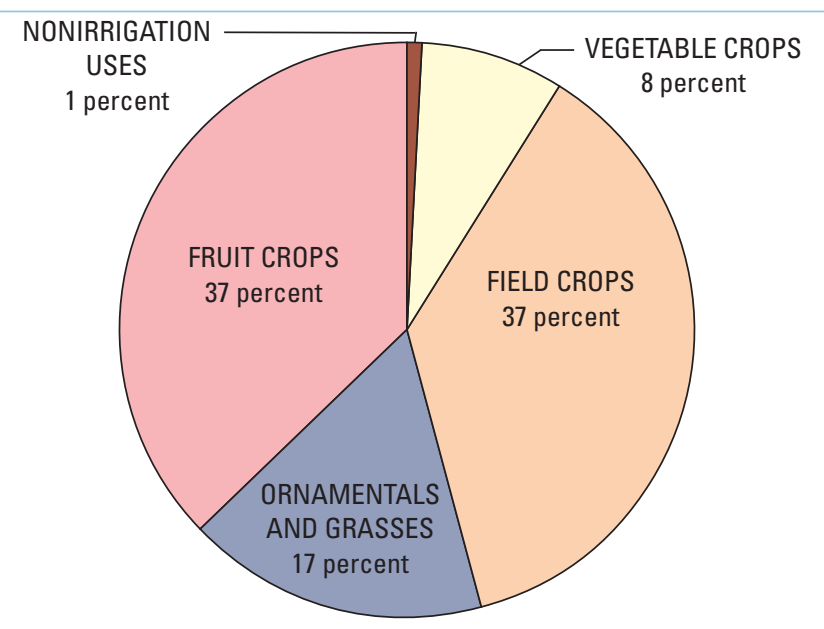

Figure 21. Agricultural self-supplied freshwater use in Florida by major crop type, 2005. 
Table 9. Acres irrigated, irrigation system type, and water use by crop type in Florida, 2005.

[Source: U.S. Geological Survey, Florida Water Science Center, U.S. Department of Agriculture (Crop Census), Florida Agricultural Statistics Service, Florida Department of Agriculture and Consumer Services, Florida Department of Environmental Protection and Northwest Florida WMD, St. Johns River WMD, South Florida WMD, Southwest Florida WMD, and Suwannee River WMD. Acreage data not available for most individual crops for 2005, compared to previous years. Values may not be identical to the values reported by the water management districts (WMD) or other agricultural agencies due to differences in data collection or crop type or to revisions in reported values. N/A, data not available]

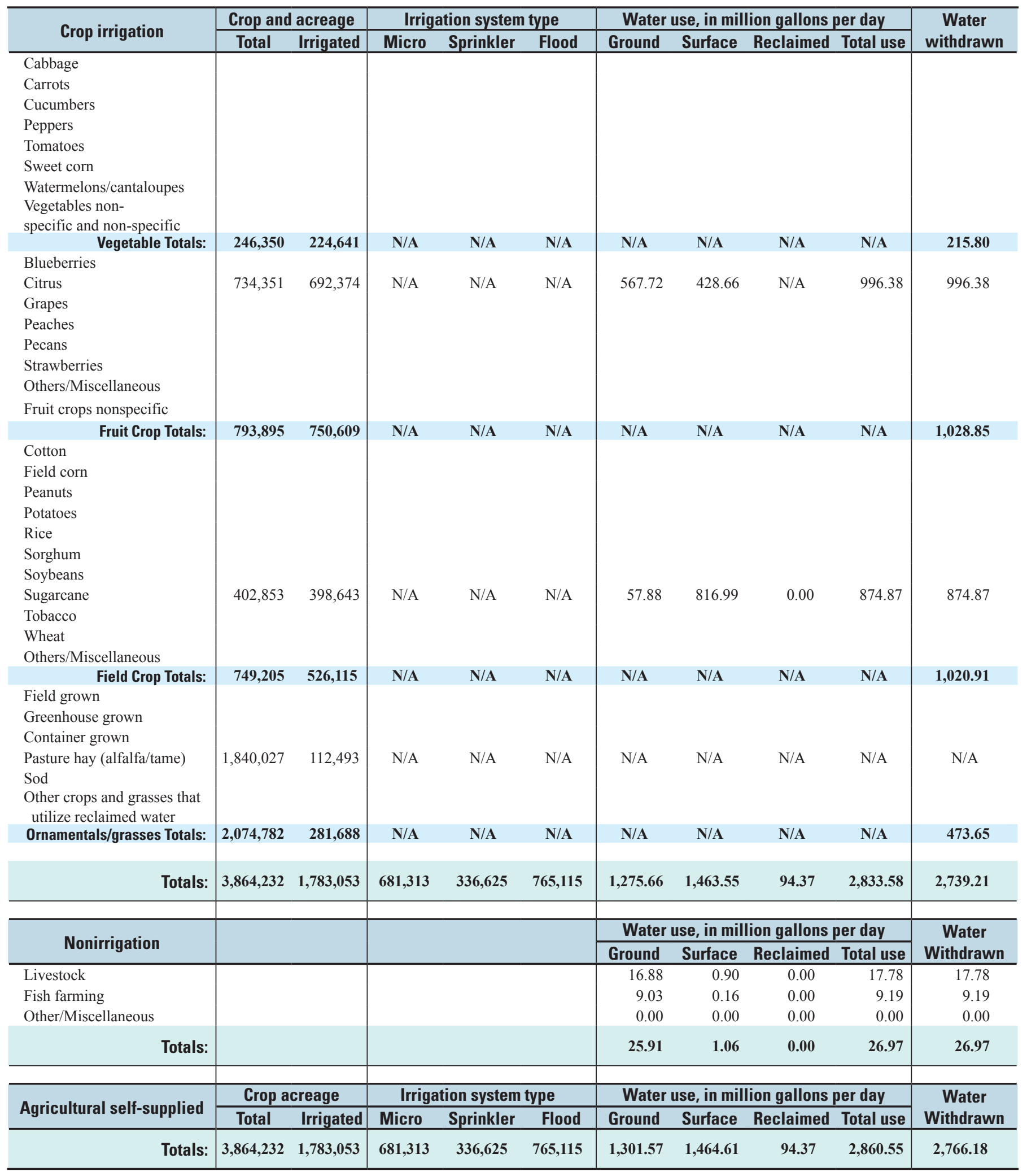


Water withdrawals for agricultural self-supplied use for 2005 were substantially lower than the previous 25 years (fig. 22). During the 1980s, water withdrawals for agricultural irrigation ranged about $2,900 \mathrm{Mgal} / \mathrm{d}$; in the $1990 \mathrm{~s}$, withdrawals ranged about $3,400 \mathrm{Mgal} / \mathrm{d}$; for 2000 , withdrawals peaked around 4,000 Mgal/d before decreasing to just under 2,800 Mgal/d in 2005. Overall, withdrawals decreased 8.5 percent between 1980 and 2005, and 29.5 percent between 2000 and 2005 (fig. 22).

Several trends in agricultural self-supplied occurred during the 25-year period between 1980 and 2005; listed below are some of the most prevalent:

- First, the increase in withdrawals in the $1980 \mathrm{~s}$ and 1990s can be attributed to the development of irrigation technology coupled with the availability of freshwater for irrigation, Florida's subtropical climate and mild winters that allow early spring crop production and the potential to harvest multiple crops per year, and the State's close proximity to east coast markets and capability to ship perishable products in a timely fashion (Marella, 1997).

- Second, higher than usual withdrawals for 2000 were the result of extreme climatic conditions that occurred throughout that year, as the State experienced severe dry conditions (Verdi and others, 2006) that caused higher than normal irrigation demands. Annual average rainfall statewide for 2000 was just over 43 in. compared to nearly 63 in. for 2005 (U.S. Department of Commerce, 2008).

- Third, a sharp decline in withdrawals for 2005 is a result of losses of irrigated acreage between 2000 and 2005 for selected crops, water restrictions imposed during 2000 that have been left in tact, more normal rainfall for 2005, and better management and conservation practices.

- Fourth, a change in how agricultural self-supplied values were estimated between previous years and 2005. The AFSIRS model was used in all WMDs for 2005, compared to the use of other models in different WMDs for prior years. The differences in models can be significant for selected crops during extreme dry or wet years.

Total irrigated acreage in Florida decreased slightly for 2005 from previous years. During 1980 and 2000, irrigated acreage remained fairly consistent between a high of 2.041 million acres in 1980 and a low of 1.836 million acres in 1985, primarily from losses due to freezes between these years. For 1980, 1985, 1990, 1995, and 2000, irrigated acreage averaged 1.950 million acres. Between 2000 and 2005, irrigated acreage decreased 4 percent, from 1.866 million acres in 2000 (Marella, 2004) to 1.783 million acres in 2005.

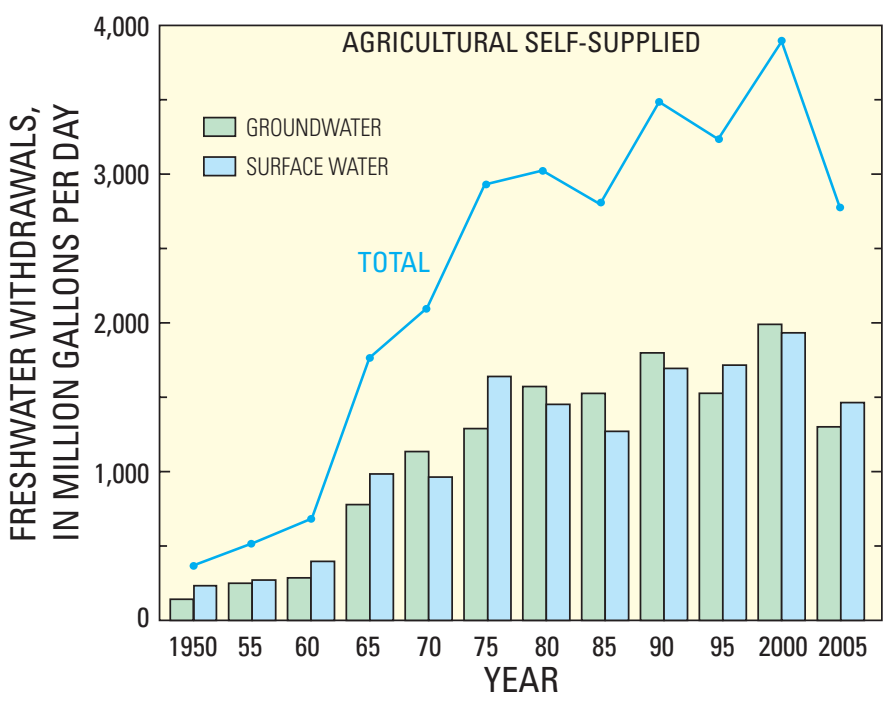

Figure 22. Historical agricultural self-supplied freshwater withdrawals in Florida by source, 1950-2005. Modified from Marella (2004).

Acreage of Florida's two largest irrigated crops decreased between 2000 and 2005; citrus lost 0.132 million acres and sugarcane lost 0.006 million acres (fig. 23). Since 2000 , citrus lost a substantial amount of acreage to hurricanes, disease (citrus canker), and encroaching urbanization (White and van Blokland, 2006). Harvested sugarcane acreage has remained at about 0.400 million acres since 1994 (Florida Department of Agriculture and Consumer Services, 2006), but has decreased since a peak in 2001 (fig. 23). Vegetable acreage (including berries, potatoes, and watermelons) has decreased from 0.300 million acres during the 1980 s and 1990 s to

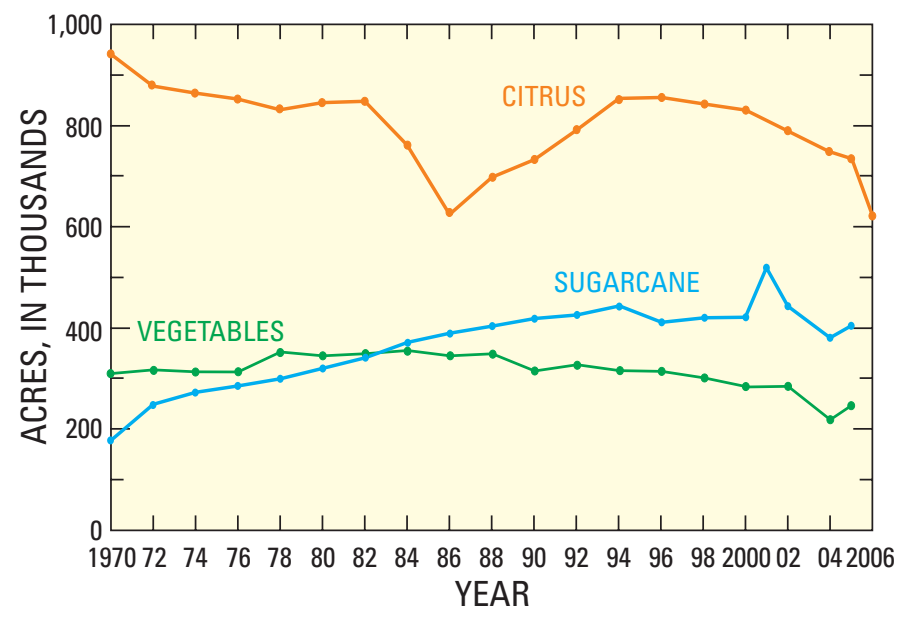

Figure 23. Historical agricultural acreage in Florida for selected crops, 1970-2006. From Florida Agricultural Statistic Service (2007), Florida Department of Agriculture and Consumer Services (2006), and Marella (2004). 
slightly more than 0.200 million acres in 2000 and 2005 (fig. 23). Because of Florida's growth in population, housing, and commercial establishments over the past 20 years, the demand for ornamentals and grass (sod) has increased substantially. Irrigated acreage for commercial flowers, foliage and woody ornamentals, as well as sod has increased from just less than 0.070 million acres in 1985 to nearly 0.120 million acres in 2005. Many ornamental plants often require more water to grow and maintain compared to traditional crops.

Another important irrigation trend in Florida is the move toward more efficient irrigation systems. In 1980, about 16 percent ( 0.300 million acres) of the acreage being irrigated statewide used micro systems, whereas more than 60 percent (1.200 million acres) was irrigated using less-efficient flood systems. By 2005, an estimated 38 percent (0.681 million acres) of the acreage being irrigated used more efficient micro-irrigation systems compared to 43 percent $(0.765$ million acres) that was irrigated using less efficient flood systems, and 19 percent ( 0.336 million acres) using sprinkler irrigation systems (fig. 24 and table 9). The increase in micro irrigation is particularly important for citrus, as nearly all of the newly replanted acreage is being irrigated by these more efficient systems, and most of the older groves have converted from flood or sprinkler systems to more efficient irrigation systems. Many other crops are utilizing these more efficient micro-irrigation systems as farmers statewide are moving away from flood or sprinkler systems to help conserve water.

In addition, the use of reclaimed wastewater, captured rainfall, and unused irrigation water (tailwater runoff) as alternative water sources has helped offset additional freshwater demands on groundwater and surface-water sources. Nearly $94 \mathrm{Mgal} / \mathrm{d}$ of reclaimed wastewater was used for agricultural crop irrigation purposes in 2005 (Florida Department of Environmental Protection, 2006).

\section{Recreational Irrigation}

Recreational irrigation includes the application of water on lands to assist in the growing of turf grass and landscape vegetation for lawns or recreation purposes and also includes water used for aesthetic purposes. Turf-grass recreation includes the golf-course irrigation (including all grass and landscape associated with golf courses); and turf-grass lawns relate to all grass and landscape irrigation associated with athletic fields, cemeteries, common public or highway areas, parks, playgrounds, and lawns (primarily nonresidential, but may include some residential). Aesthetic uses include water used to fill or maintain nonagricultural ponds. Recreational irrigation is a relatively new category beginning with the 1995 compilation; however, these data have been collected since 1985 and were included under the agricultural irrigation category for 1985 and 1990. Water used for recreational irrigation may be obtained from a public water supplier, reclaimed wastewater, or self-supplied. Acreage and water-use values reported in this section are for reclaimed wastewater

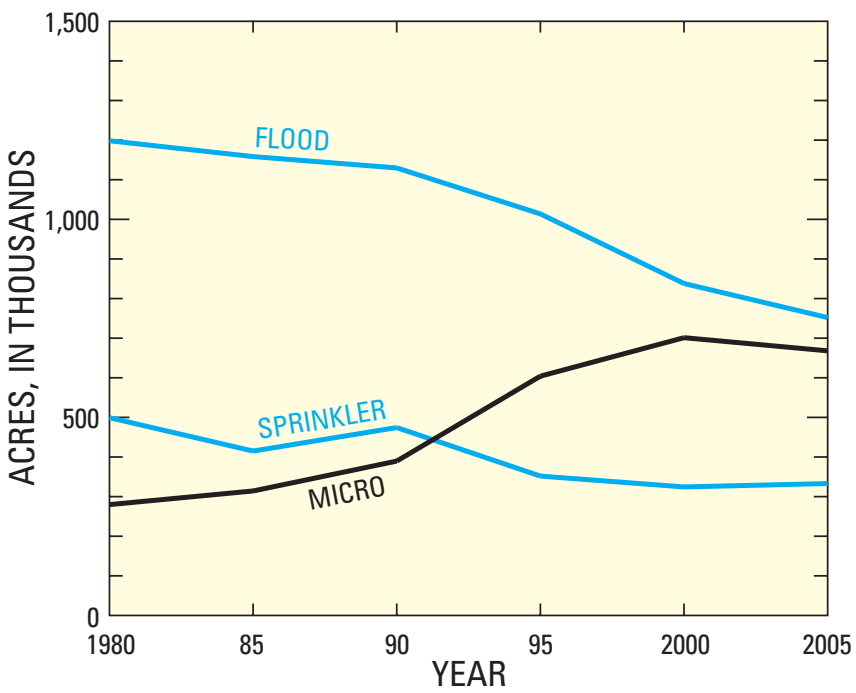

Figure 24. Historical agricultural acreage irrigated in Florida by major irrigation system type, 1980-2005. Modified from Marella (1997, 1999).

or self-supplied withdrawals only, and uses of public-supply water for recreational irrigation would be included under the other uses of public supply (as presented in table 5).

Water withdrawals for recreational irrigation totaled $330 \mathrm{Mgal} / \mathrm{d}$ of freshwater in 2005 (table 10). Groundwater supplied 52 percent $(171 \mathrm{Mgal} / \mathrm{d})$ and surface water supplied 48 percent (159 Mgal/d) (table 10). Reclaimed wastewater obtained from treated domestic wastewater facilities supplied an additional $321 \mathrm{Mgal} / \mathrm{d}$ of water used for recreational irrigation purposes in 2005 (Florida Department of Environmental Protection, 2006). The Floridan aquifer system supplied more than one-half (nearly 55 percent) of groundwater withdrawals (fig. 25), whereas local ponds, lakes, and canals contributed

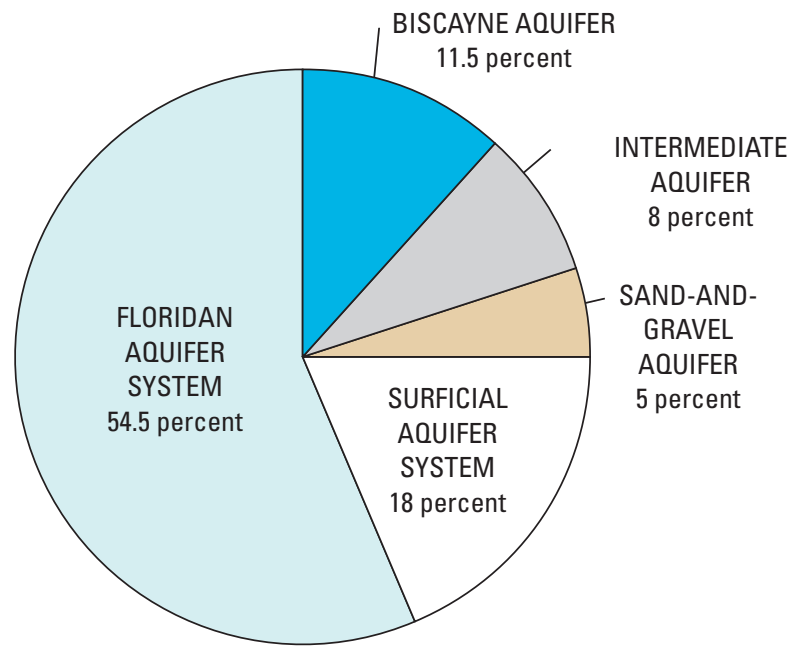

Figure 25. Recreational irrigation groundwater withdrawals in Florida by principal aquifer, 2005. 
Table 10. Recreational irrigation water withdrawals in Florida by county, 2005.

[Source: U.S. Geological Survey, Florida Water Science Center - Tallahassee; all values in million gallons per day]

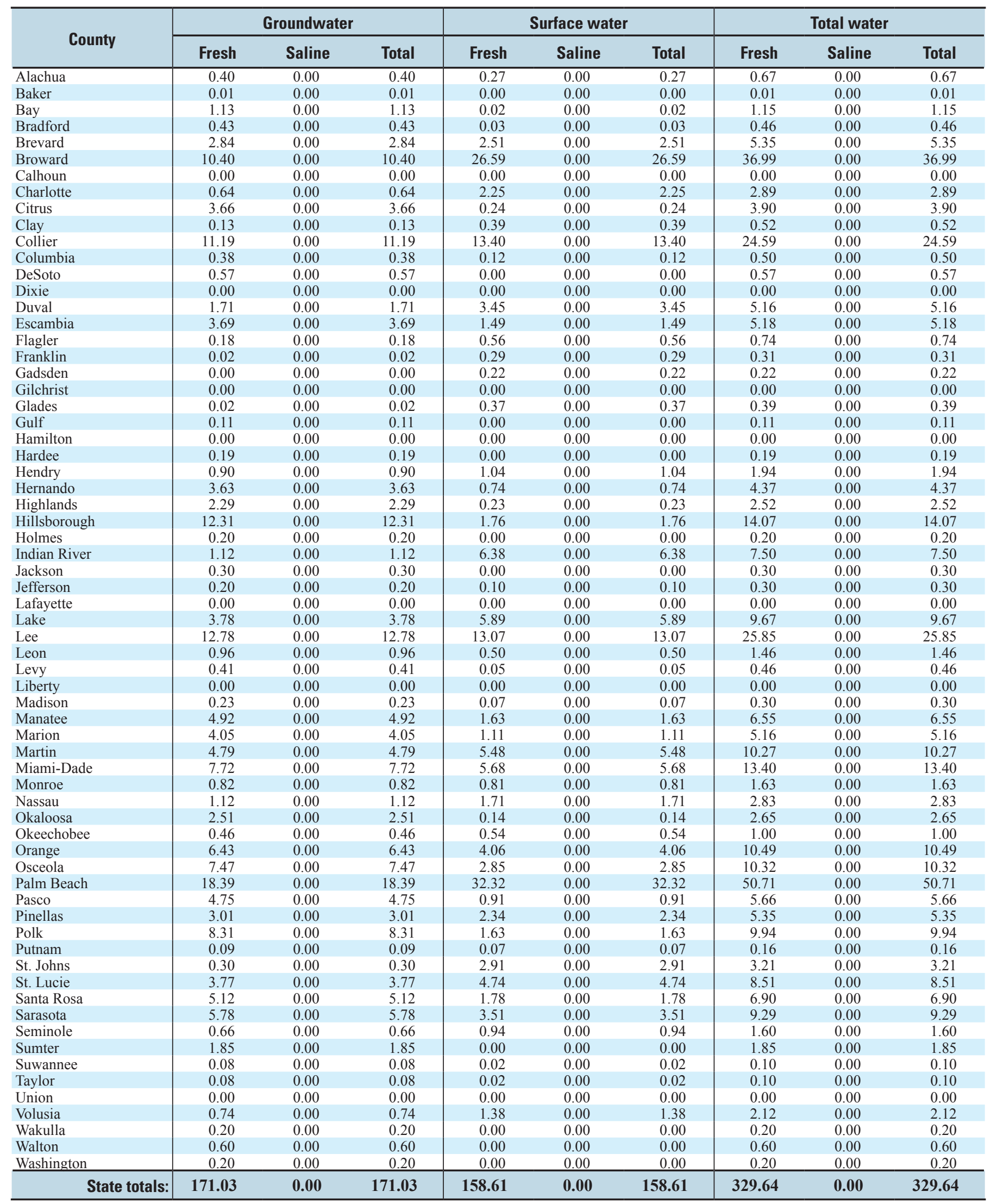


to the majority of surface-water withdrawals. In many cases, these surface-water sources are augmented with groundwater or reclaimed wastewater or are designed to catch unused irrigation water and rainfall runoff in an effort to maintain water levels or storage for future irrigation needs. About $110 \mathrm{Mgal} / \mathrm{d}$ of reclaimed wastewater was used in 2005 for golf-course irrigation directly or indirectly by augmenting irrigation ponds (Florida Department of Environmental Protection, 2006).

Monthly withdrawals for recreational irrigation had a large seasonal variation. Withdrawals were greatest during March, April, and May (accounting for 36 percent of the water used) and lowest in June, July, August, and September for 2005 (fig. 26). A seasonal fluctuation of more than $300 \mathrm{Mgal} / \mathrm{d}$ in 2005 resulted from normal dry conditions during the spring months and normal summer rainfall. This pattern of seasonal withdrawals for recreational irrigation in Florida is normal.

Nearly 42 percent of water withdrawals for recreational irrigation came from Palm Beach, Broward, Lee, and Collier Counties (table 10). For these counties, and other counties in central and southern Florida, recreational irrigation occurs year long. Pinellas and Palm Beach Counties were the largest user of reclaimed wastewater for recreational irrigation in 2005 (Florida Department of Environmental Protection, 2006).

Golf-course irrigation was the largest user of water for this category in 2005 , accounting for $225 \mathrm{Mgal} / \mathrm{d}$ (69 percent) of water withdrawals and $110 \mathrm{Mgal} / \mathrm{d}$ (34 percent) of reclaimed wastewater. Of the nearly 0.190 million acres

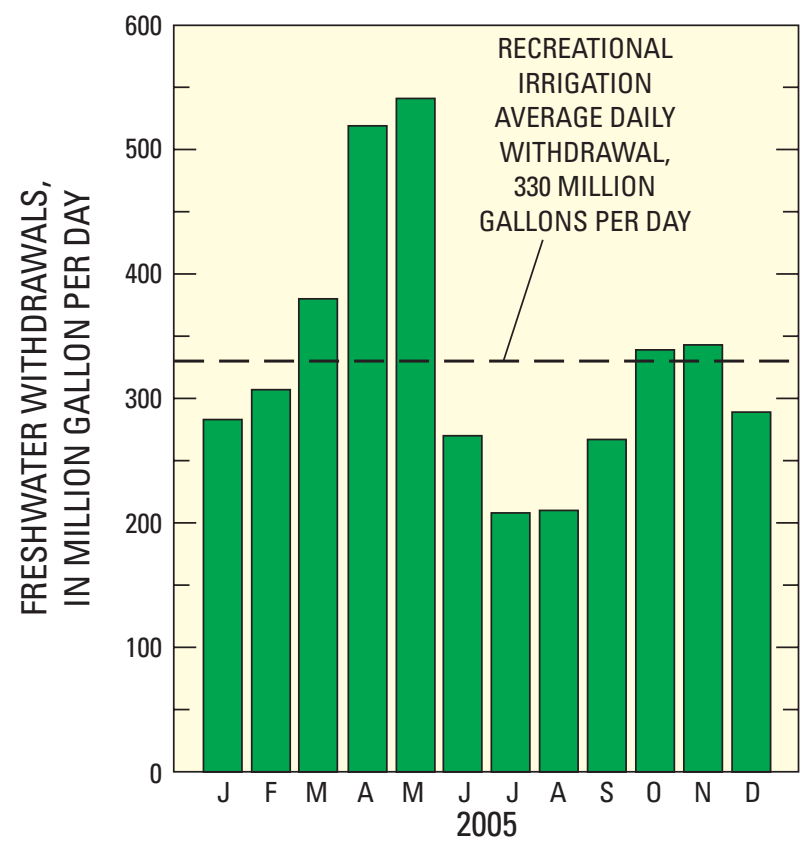

Figure 26. Average daily recreational irrigation freshwater withdrawals by month in Florida, 2005. irrigated for recreational purposes, nearly 70 percent was for golf courses and the remaining 30 percent was for other turf-grass or landscape uses. In 2005, an estimated 1,100 golf courses were located in Florida (National Golf Foundation, 2006), covering an estimated 0.134 million acres, of which nearly 87 percent $(0.117$ million acres) was irrigated.

Water withdrawals for recreational irrigation increased 82 percent between 1985 and 2005 (fig. 27), and golf-course acreage increased 62 percent. More recently, water withdrawals for recreation decreased 20 percent, but irrigated golfcourse acreage increased 6 percent. Golf-course irrigation is heavily dependent upon rainfall; normal rainfall deviations during a year can dramatically change annual water demands. In addition, golf courses in central and south Florida irrigate all year, and those along the coast must overcome sandy soils and high evaporation rates due to the seabreeze. These factors all contribute to golf-course irrigation water demands. Also, during the dry conditions across most of Florida in 2000, water demands were higher than normal compared to 2005 when rainfall was more normal. Annual rainfall statewide for 2000 was just over 43 in. compared to nearly 63 in. for 2005 (U.S. Department of Commerce, 2008). Some of this demand was offset by the use of reclaimed water as the primary water source and the use of onsite irrigation ponds that depended on runoff. However, when rainfall did not provide enough water to maintain levels in the ponds, wells were often used as an irrigation source to augment water levels.

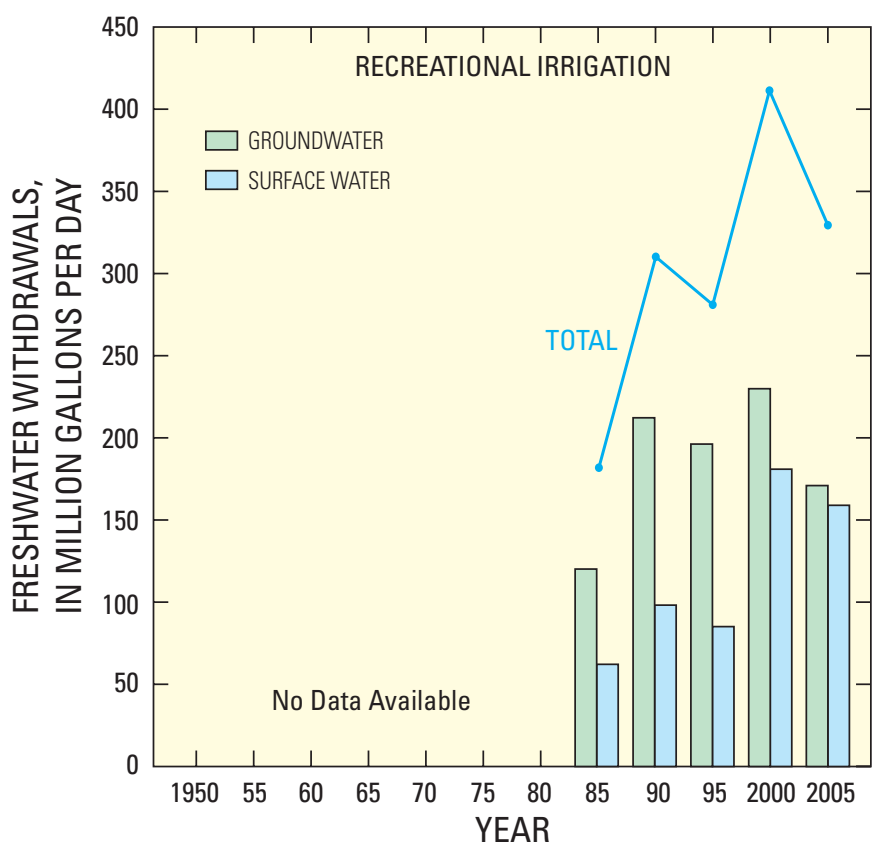

Figure 27. Historical recreational irrigation freshwater withdrawals in Florida by source, 1985-2005. Modified from Marella (2004). 


\section{Power Generation}

Power-generation use includes water withdrawals from thermoelectric power-generation facilities (fossil fuel or nuclear) and water used at hydroelectric facilities. A total of 66 active power-generation facilities were in operation in 2005 with an additional 4 powerplants used for standby use only (used only during extreme peak demands or while primary plants are down due to maintenance). Of the 66 active facilities, 14 small, private, or secondary power-generating facilities are used for peak loads or to generate electricity as a byproduct of their main function; 2 hydroelectric power-generating facilities are located in Florida.

More than $12,042 \mathrm{Mgal} / \mathrm{d}$ of water was withdrawn for power-generation purposes in 2005 (table 11). Saline water was the source of 11,484 Mgal/d (95 percent) and freshwater was the source of $558 \mathrm{Mgal} / \mathrm{d}$ ( 5 percent) of water withdrawals for power generation. Of the saline-water withdrawals, nearly all (99.9 percent) was from surface-water sources, and of the freshwater withdrawals, 97 percent was from surface-water sources (table 11). Overall, 98 percent $(11,838 \mathrm{Mgal} / \mathrm{d})$ of the total freshwater and saline-water withdrawals for power generation was used for once-through cooling purposes in 2005. Most of the water withdrawals for once-through cooling is returned to its source immediately after use. More than $203,800 \mathrm{GWh}$ of total gross power was generated from the 66 inventoried facilities in Florida for 2005. Florida ranked second in the nation to California in saline-water withdrawals for power generation in 2005 (Kenny and others, 2009). Withdrawals (fresh and saline) for power generation represent nearly two-thirds (66 percent) of all water withdrawals in Florida for 2005.

Most of the surface water was withdrawn from bays or rivers along the coast, which included the Anclote River (Pasco County), Caloosahatchee River (Lee County), Crystal River and the Gulf of Mexico (Citrus County), Escambia River (Escambia County), the Indian River (Brevard, Indian

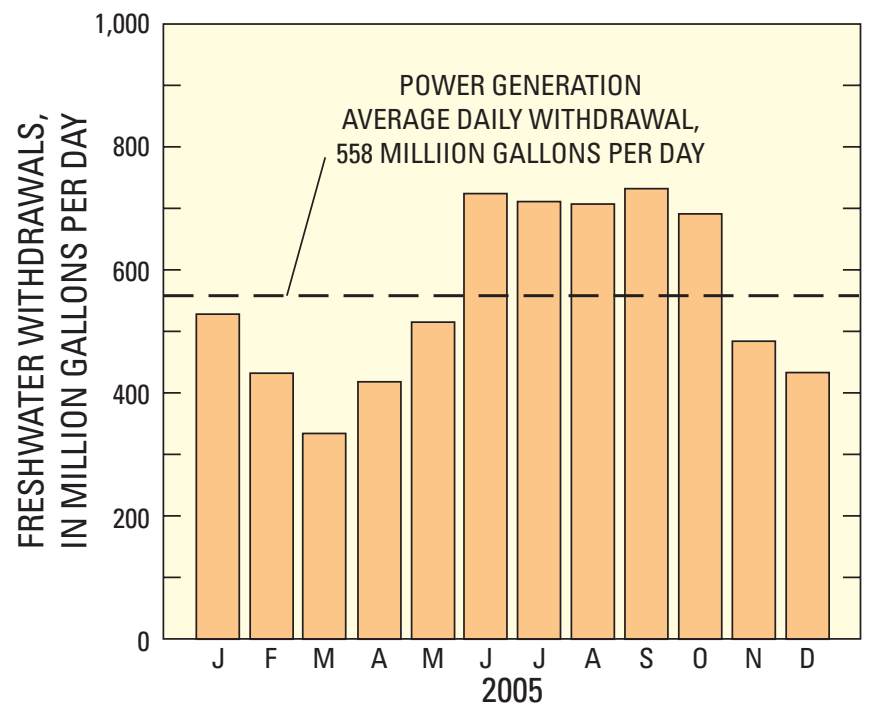

Figure 28. Average daily power-generation freshwater withdrawals by month in Florida, 2005.
River, and St. Lucie Counties), the St. Johns River (Duval and Putnam Counties), and Tampa Bay (Hillsborough and Pinellas Counties). Although several of these bays or rivers are considered freshwater, the point of powerplant withdrawal is often tidally influenced, and the water may be fresh, brackish, or saline due to tidal flows (McPherson and Hammett, 1991). Water withdrawals reported in this report are considered saline at most of these plants unless they are permitted by the WMD as freshwater. The Floridan aquifer system was the source of 82 percent $(14.5 \mathrm{Mgal} / \mathrm{d})$ of fresh groundwater withdrawals for power generation in 2005. Public-supply deliveries to thermoelectric powerplants used for domestic purposes or as boiler make-up water totaled nearly $5 \mathrm{Mgal} / \mathrm{d}$, but another $21 \mathrm{Mgal} / \mathrm{d}$ of reclaimed wastewater was used directly for cooling purposes; however, a much larger amount of cooling water was obtained from lakes, ponds, or wetlands supplemented by reclaimed wastewater.

Monthly freshwater withdrawals for power generation fluctuated seasonally during 2005 - the highest withdrawals were in June through October, as power demands increase due to hot weather (fig. 28). The largest amount of freshwater withdrawals were from Escambia County, and the largest amount of saline-water withdrawals were from Pasco County (table 11). Powerplants in Duval, Hillsborough, Orange, Polk, and Wakulla Counties used reclaimed wastewater to augment cooling water.

Total water withdrawals for power generation increased steadily between 1955 and 1980, when withdrawals peaked at 15,500 Mgal/d (fig. 29); but since 1985, withdrawals have decreased or nearly constant. Between 1990 and 2005, withdrawals for saline water increased 12 percent, but freshwater decreased 29 percent. Between 2000 and 2005, withdrawals for saline water decreased 4 percent and freshwater decreased 15 percent. However, the total amount of gross power generated statewide increased 59 percent $(75,500 \mathrm{GWh})$ between 1990 and 2005 and 20 percent $(34,700 \mathrm{GWh})$ between 2000 and 2005 .

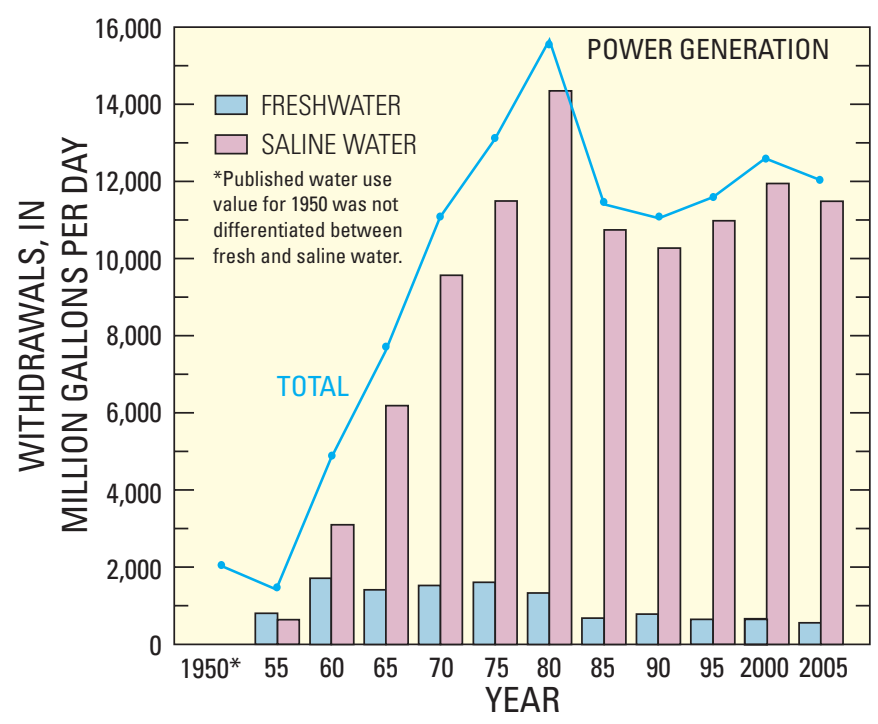

Figure 29. Historical power-generation water withdrawals in Florida by source, 1950-2005. Modified from Marella (2004). 
Table 11. Power-generation water withdrawals in Florida by county, 2005.

[Source: U.S. Geological Survey, Florida Water Science Center - Tallahassee; all values in million gallons per day]

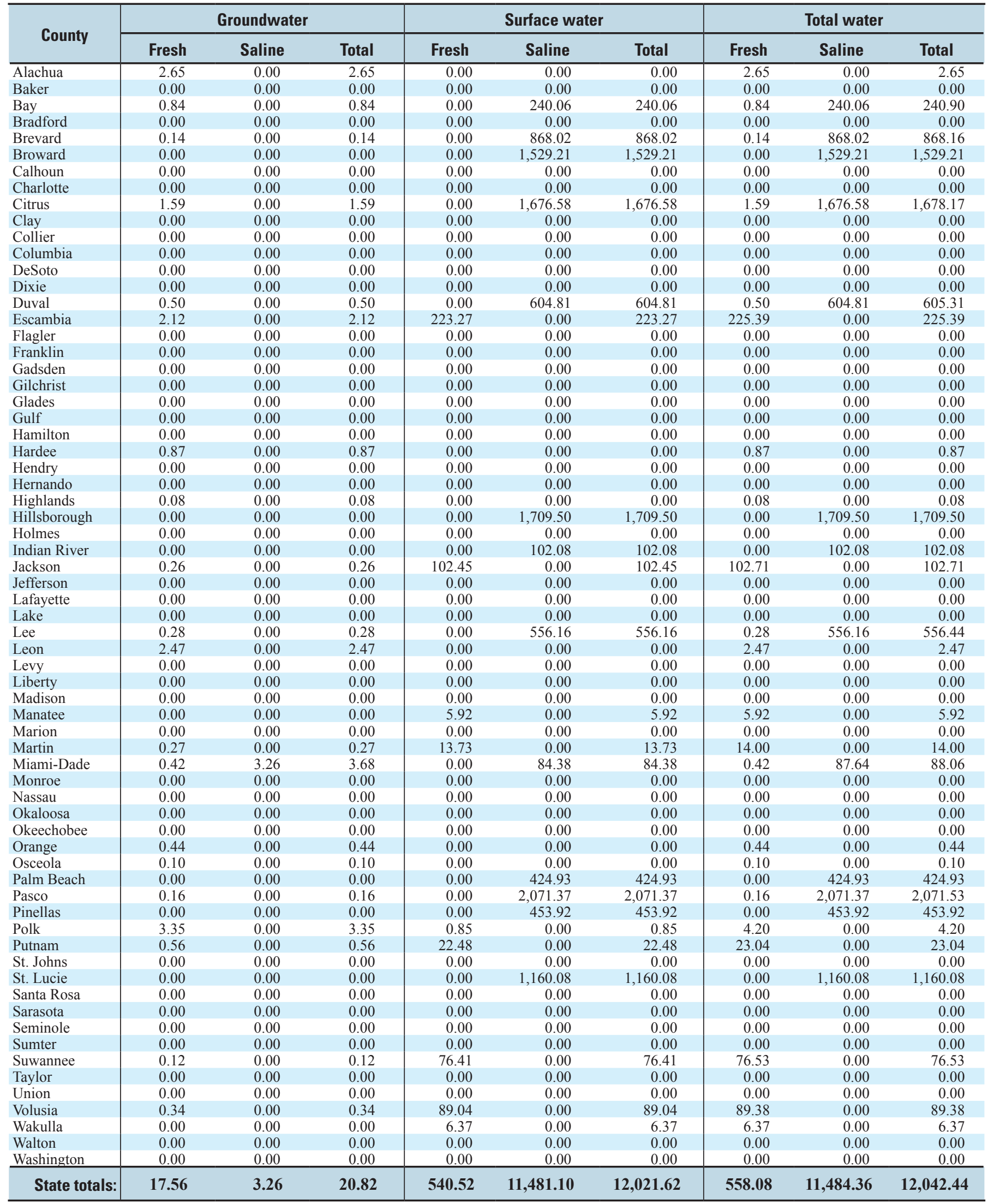


The reduction in freshwater withdrawals over the past 25 years is due to an increase in water efficiency of existing or new facilities (Hughes, 1975). In addition, several existing powerplants and many new plants withdraw water only to augment or replenish the water in the cooling ponds. Furthermore, differences among years could have occurred due to facility downtime caused by plant maintenance or modernization. Significant downtime can substantially reduce the annual average water withdrawals at powerplants, and this is particularly evident when data are collected only every 5 years.

\section{Water Management Districts}

The Florida Water Resources Act of 1972 established authority for management of the State's water resources through five WMDs that operate under the general supervision of the FDEP (formerly the Florida Departments of Natural Resources and Florida Departments of Environmental Regulation) (Fernald and Patton, 1984). These five WMDs, which encompass the entire State, are Northwest Florida WMD, St. Johns River WMD, South Florida WMD, Southwest Florida WMD, and Suwannee River WMD (fig. 2).

Of the 17.92 million people who resided in Florida during 2005, 41 percent (7.36 million people) resided in SFWMD, followed by SJRWMD and SWFWMD with 25 percent each (4.46 million and 4.44 million people, respectively), NWFWMD with 7.5 percent (1.34 million people), and SRWMD with 1.5 percent ( 0.32 million people) (fig. 30). SFWMD included the largest number of residents (6.88 million people) served by public-supply water systems (fig. 30), and SJRWMD has the largest self-supplied population ( 0.60 million people) in 2005 .

The largest amount of freshwater withdrawals was from SFWMD, which was one-half (50 percent) of Florida's total freshwater withdrawals (fig. 31 and table 12). The percentage of the total freshwater withdrawals in the other WMDs were: SJRWMD, 19 percent; SWFWMD, 16 percent; NWFWMD, 10 percent; and SRWMD, 5 percent. SFWMD accounted for the largest amount of freshwater withdrawals for publicsupply use (47 percent), commercial-industrial self-supplied use (23 percent), agricultural self-supplied use (69 percent), and recreational irrigation use (59 percent). NWFWMD accounted for the largest amount of freshwater withdrawals for power-generation use (61 percent) and SWFWMD accounted for the largest amount of saline-water withdrawals for power-generation use (49.5 percent) (table 12). SFWMD accounted for the largest amount of fresh groundwater and surface-water withdrawals in 2005, and SWFWMD accounted for the largest amount of saline-water withdrawals in 2005 (fig. 32 and table 12).

Since water-use data were first compiled by the WMDs in 1975, total freshwater withdrawals decreased in NWFWMD (13 percent), SJRWMD (17 percent), and SWFWMD (30 percent), and increased in SFWMD (37 percent) and SRWMD (6 percent) between 1975 and 2005. Excluding withdrawals for power generation, freshwater

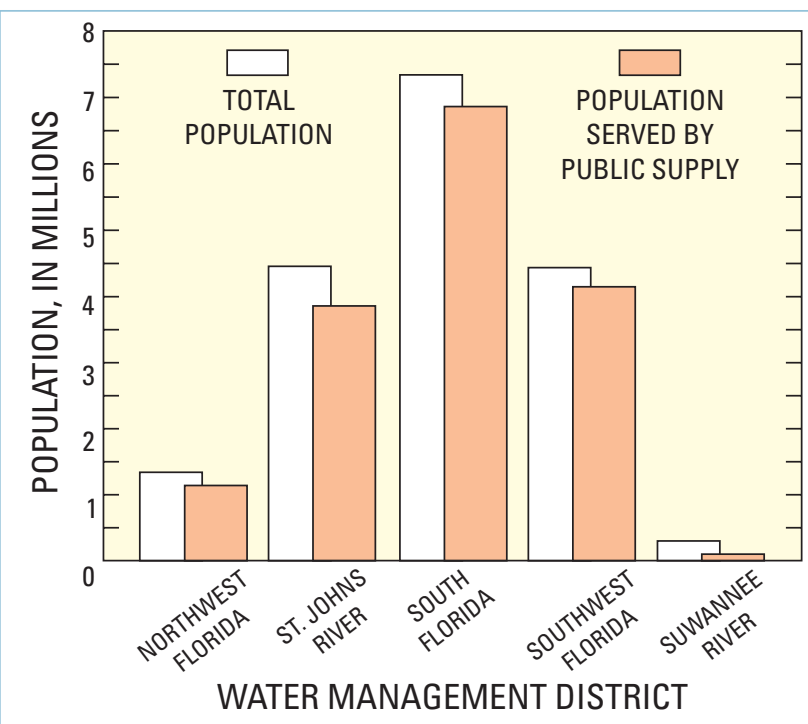

Figure 30. Population and population served by public supply in Florida by water management district, 2005.

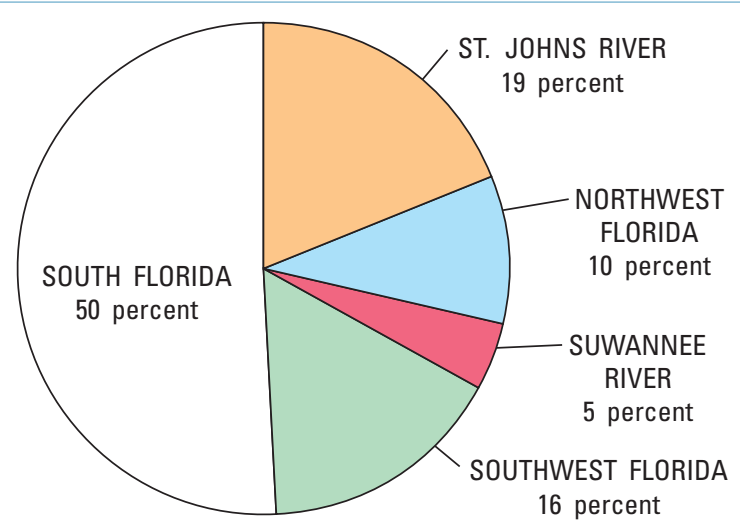

Figure 31. Freshwater withdrawals in Florida by water management district, 2005.

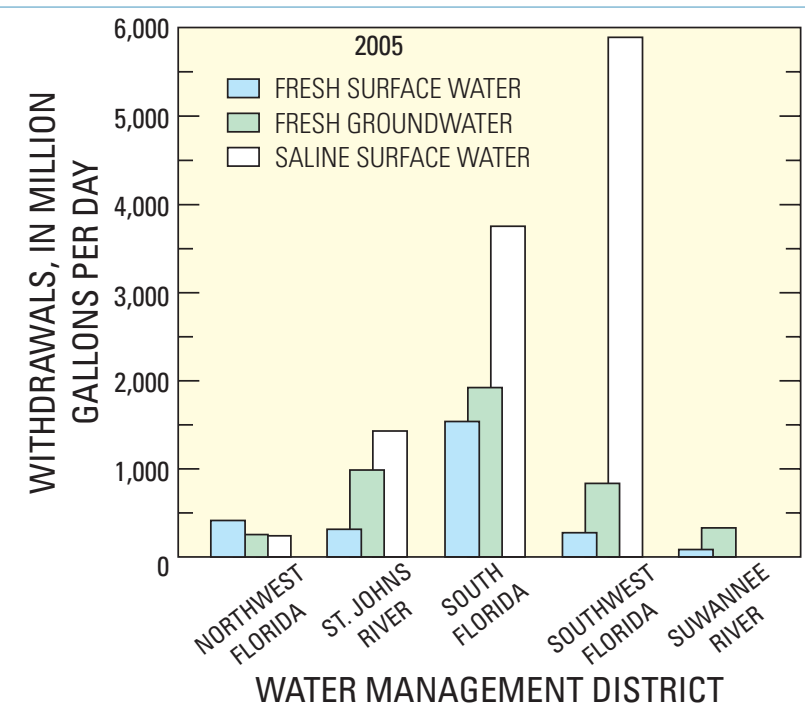

Figure 32. Freshwater and saline-water withdrawals in Florida by water management district, 2005. 
Table 12. Water withdrawals by category in Florida by water management district, 2005.

[Source, U.S. Geological Survey, Florida Water Science Center - Tallahassee; the St. Johns River Water Management District (2006); and the Southwest Florida Water Management District (2007); All values in million gallons per day; district totals may not be identical to data reported or published by the districts due to differences in data-collection procedures and categories of use or revisions in reported values; general locations of districts are shown in fig. 2]

\begin{tabular}{|c|c|c|c|c|c|c|}
\hline Water Management District & & Fresh ground & Fresh surface & $\begin{array}{c}\text { Total } \\
\text { freshwater }\end{array}$ & $\begin{array}{c}\text { Total } \\
\text { saline water }\end{array}$ & $\begin{array}{c}\text { Total } \\
\text { all water }\end{array}$ \\
\hline \multicolumn{7}{|l|}{ Northwest Florida (NWFWMD) } \\
\hline Public supply & & 139.19 & 45.11 & 184.30 & 0.00 & 184.30 \\
\hline Domestic self-supplied & & 19.15 & 0.00 & 19.15 & 0.00 & 19.15 \\
\hline Commercial-industrial-mining & & 43.36 & 23.97 & 67.33 & 0.00 & 67.33 \\
\hline \multirow[t]{2}{*}{ Power generation } & & 5.69 & 332.09 & 337.78 & 240.06 & 577.84 \\
\hline & Totals: & 254.37 & 414.51 & 668.88 & 240.06 & 908.94 \\
\hline \multicolumn{7}{|l|}{ St. Johns River (SJRWMD) } \\
\hline Public supply & & 565.12 & 15.87 & 580.99 & 0.00 & 580.99 \\
\hline Recreational irrigation & & 16.09 & 28.25 & 44.34 & 0.00 & 44.34 \\
\hline \multirow[t]{2}{*}{ Power generation } & & 2.15 & 111.52 & 113.67 & $1,574.91$ & $1,688.58$ \\
\hline & Totals: & 986.83 & 313.69 & $1,300.52$ & $1,576.10$ & $2,876.62$ \\
\hline \multicolumn{7}{|l|}{ South Florida (SFWMD) } \\
\hline Public supply & & $1,135.63$ & 53.09 & $1,188.72$ & 0.00 & $1,188.72$ \\
\hline Domestic self-supplied & & 45.64 & 0.00 & 45.64 & 0.00 & 45.64 \\
\hline Commercial-industrial-mining & & 64.52 & 49.30 & 113.82 & 0.00 & 113.82 \\
\hline Agricultural self-supplied & & 596.42 & $1,311.87$ & $1,908.29$ & 0.00 & $1,908.29$ \\
\hline Recreational irrigation & & 84.64 & 110.43 & 195.07 & 0.00 & 195.07 \\
\hline \multicolumn{7}{|l|}{ Southwest Florida (SWFWMD) } \\
\hline Agricultural self-supplied & & 298.55 & 13.71 & 312.26 & 0.00 & 312.26 \\
\hline Recreational irrigation & & 53.92 & 14.98 & 68.90 & 0.00 & 68.90 \\
\hline \multirow[t]{2}{*}{ Power generation } & & 6.05 & 6.77 & 12.82 & $5,911.37$ & $5,924.19$ \\
\hline & Totals: & 834.71 & 274.91 & $1,109.62$ & $5,911.37$ & $7,020.99$ \\
\hline \multicolumn{7}{|l|}{ Suwannee River (SRWMD) } \\
\hline Public supply & & 15.70 & 0.00 & 15.70 & 0.00 & 15.70 \\
\hline Domestic self-supplied & & 20.53 & 0.00 & 20.53 & 0.00 & 20.53 \\
\hline Commercial-industrial-mining & & 81.44 & 4.86 & 86.30 & 0.00 & 86.30 \\
\hline Agricultural self-supplied & & 121.97 & 2.51 & 124.48 & 0.00 & 124.48 \\
\hline Recreational irrigation & & 1.29 & 0.46 & 1.75 & 0.00 & 1.75 \\
\hline \multirow[t]{2}{*}{ Power generation } & & 2.60 & 76.41 & 79.01 & 0.00 & 79.01 \\
\hline & Totals: & 243.53 & 84.24 & 327.77 & 0.00 & 327.77 \\
\hline \multicolumn{2}{|c|}{ State totals: } & $4,247.36$ & $2,625.77$ & $6,873.13$ & $11,485.55$ & $18,358.68$ \\
\hline
\end{tabular}


withdrawals increased between 1975 and 2005 in SRWMD (82 percent), SFWMD (36 percent), NWFWMD (18 percent), and SJRWMD (12 percent), and decreased in SWFWMD (6.5 percent) during this period (fig. 33). Between 2000 and 2005, freshwater withdrawals (excluding withdrawals for power generation) decreased in SWFWMD (28 percent), SJRWMD (19 percent), SFWMD (12.5 percent), and NWFWMD (8 percent), and increased in SRWMD

(13 percent). Most of the change between 1975 and 2005 was a result of an increase in population and irrigated acreage. But, the more recent change between 2000 and 2005, was due to an increase in rainfall between 2000 compared to 2005, and a decrease in irrigated acreage for selected crops over this time.

Between 1975 and 2005, fresh groundwater withdrawals fluctuated in all five WMDs, peaking in 2000 (fig. 34). More recently, fresh groundwater withdrawals decreased between 2000 and 2005, except for SRWMD (fig. 34). Excluding withdrawals for power generation, groundwater has been the primary source of water in all five WMDs since 1975.

Increases in population and irrigated acreage over this 30 -year period have lead to increases in groundwater withdrawals in all WMDs. But, more recently, withdrawals have declined as a result of decreases in irrigated acreage coupled with increased conservation and water restrictions.

Fresh surface-water withdrawals have decreased between 1975 and 2005 in all but SFWMD (fig. 35). Most of the decrease in the other four WMDs occurred in power-generation withdrawals during this period, along with small declines in fresh surface used for agricultural irrigation or commercial-industrial self-supplied. Between 1975 and 2005, fresh surface-water withdrawals fluctuated in SFWMD, peaking in 2000 (fig. 35). Nearly all of this increase was a result of increases in irrigated acreage, but the decrease between 2000 and 2005 was a result of a decrease in irrigated acreage along with higher rainfall in 2005 compared to 2000 .

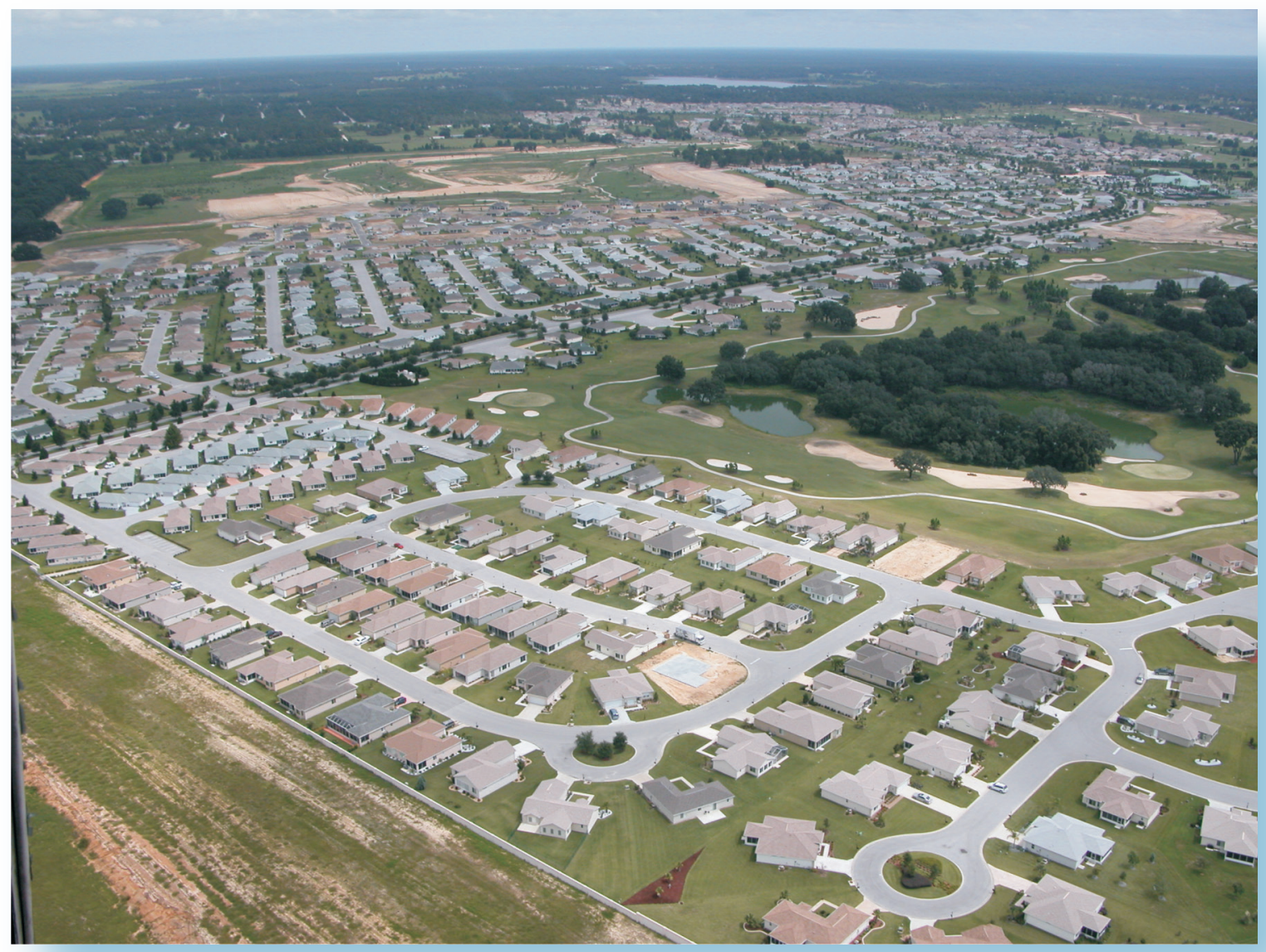

View of urban development in central Florida. Photograph courtesy of H. Means, Florida Geological Survey. 


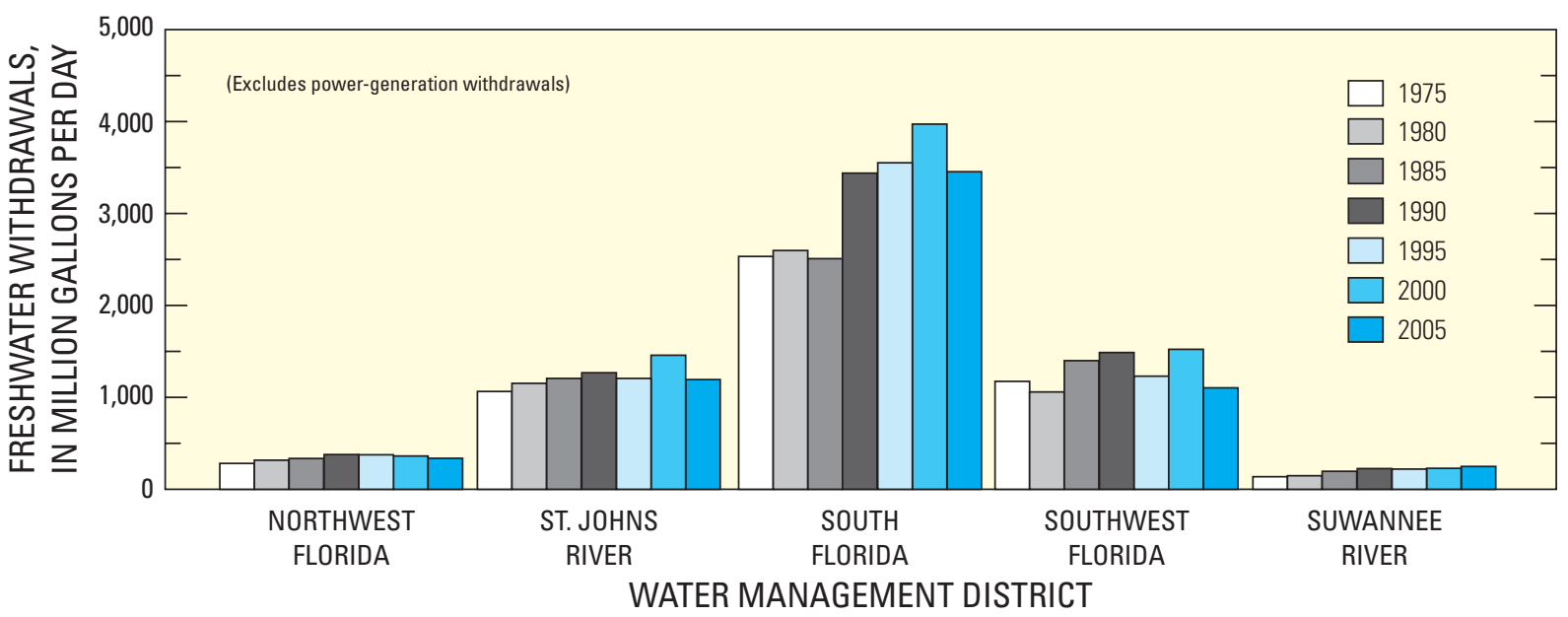

Figure 33. Historical freshwater withdrawals in Florida by water management district, 1975-2005. Modified from Marella (2004).

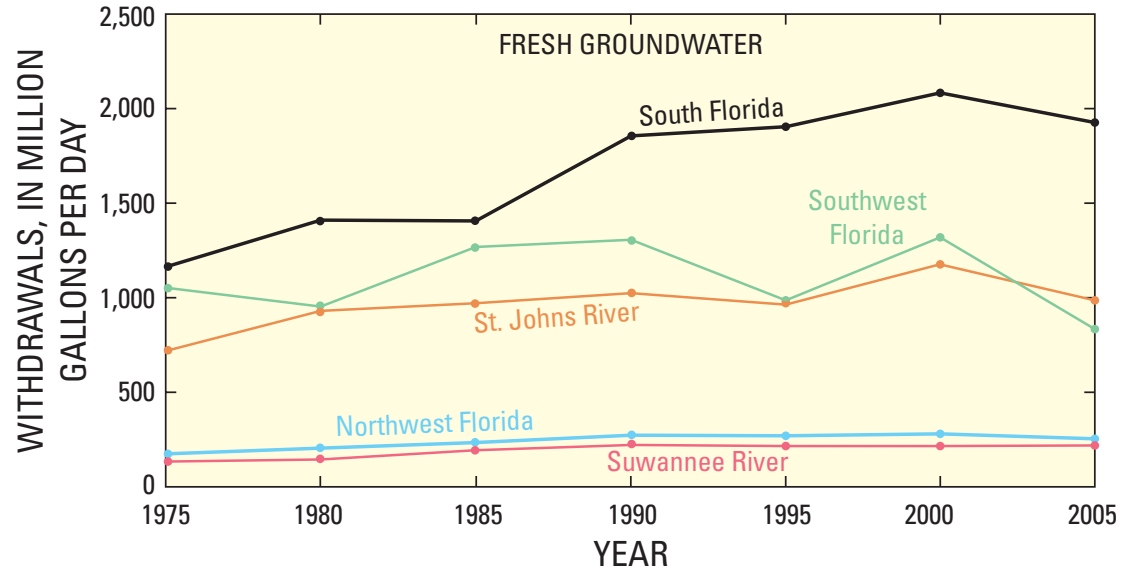

Figure 34. Historical fresh groundwater withdrawals in Florida by water management district, 1975-2005. Modified from Marella (2004).

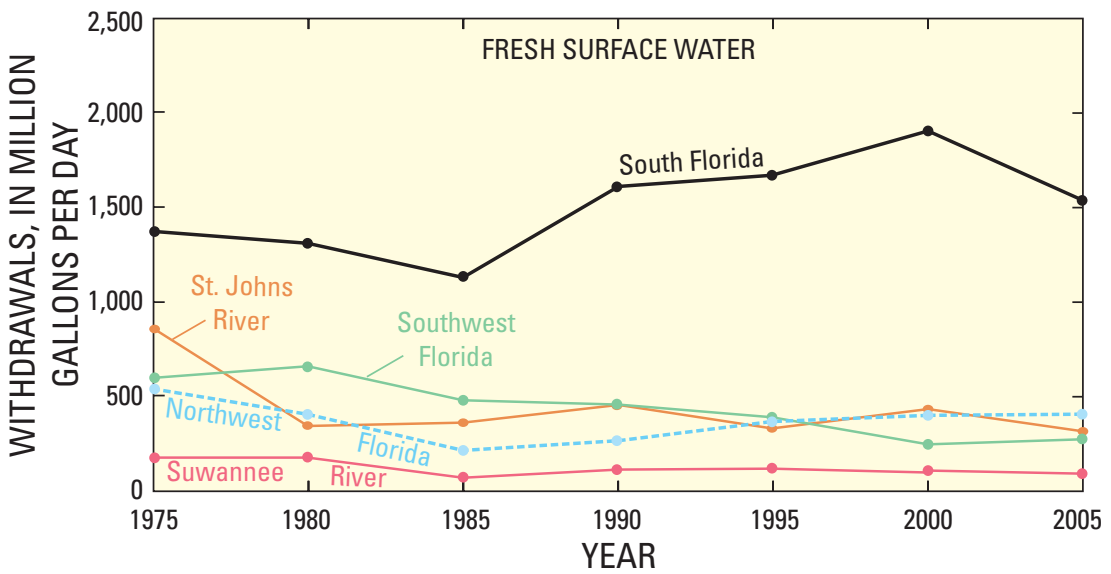

Figure 35. Historical fresh surface-water withdrawals in Florida by water management district, 1975-2005. Modified from Marella (2004). 
Water Withdrawal Trends, 1950-2005

Statewide withdrawal and water-use estimates have been compiled for Florida every 5 years since 1950; however, variations in historical water-use values are sometimes difficult to assess because of differences in data-collection techniques and sources of information through the years (Marella, 2004). Since 1970, statewide water-use data for all withdrawal categories have been collected, tabulated, and published eight times by many agencies (five WMDs, the Florida Geological Survey, FDEP, and the USGS). It is important to realize that when water-use data are only compiled in 5-year intervals, any unique circumstance occurring within a year can influence the values for that year and can make comparing trends somewhat difficult. For example, water withdrawals for 2000 were very high due to extreme dry conditions during that year, and when compared to previous years, it appears that water use was on the increase. For 2005, a more normal year for rainfall, it appears withdrawals decreased based on the 2000 values. Annual rainfall statewide for 2000 was just over 43 in. compared to nearly 63 in. for 2005 (U.S. Department of Commerce, 2008). For the six statewide inventories between 1980 and 2005, the effect of rainfall on water demands is evident by the fluctuation in agricultural water withdrawals, as water demands are higher in drier years and lower in wetter years (fig. 36). For public supply, rainfall has less of an effect on withdrawals even though a significant percentage of water used for public supply is for lawn watering (fig. 36). Average rainfall for Florida between 1905 and 2005 was estimated at 54 in. (U.S. Department of Commerce, 2008).

Total water (fresh and saline) withdrawals in Florida increased 15,700 Mgal/d (600 percent) between 1950 and 2005, while the population of Florida increased by 15.15 million (550 percent) during this 55 -year period (fig. 37 and table 13). Between 1990 and 2005, total withdrawals increased $400 \mathrm{Mgal} / \mathrm{d}$ (2 percent), while the population increased 4.98 million (38 percent). More recently, total withdrawals decreased nearly $1,790 \mathrm{Mgal} / \mathrm{d}$ ( 9 percent), while the total population increased by 1.94 million (12 percent) between 2000 and 2005.

Overall, saline-water withdrawals, which were nearly all for power generation, were highest in 1977 and 1980 (table 13) as power-generation demands peaked during this time (fig. 29). Since then, power-generation water demands have decreased due to the increase in water efficiency and the recycling of cooling water after routing the water to cooling ponds or cooling towers. Between 1975 and 2005, gross power generated in Florida increased by 122,700 GWh (151 percent), but saline-water withdrawals remained nearly the same (11,391 Mgal/d in 1975 compared to 11,481 Mgal/d in 2005).
Between 1975 and 2005, freshwater withdrawals fluctuated statewide, peaking in 2000 (fig. 37 and table 13). Freshwater withdrawals in Florida are primarily for agricultural irrigation and public supply (77 percent of total freshwater withdrawals in 2005) and, therefore, are influenced by population, irrigated acreage, and rainfall. Florida's population increased by 9.44 million people between 1975 and 2005 (table 13) and, as a result, freshwater withdrawals for public supply increased 126 percent between 1975 and 2005. Public supply accounted for 37 percent of freshwater withdrawals in 2005 compared to 17 percent in 1975. Irrigated acreage decreased by 3 percent between 1975 and 2005 and, coupled with the use of more efficient irrigation systems, freshwater withdrawals for agricultural irrigation decreased 6 percent between 1975 and 2005. Agricultural irrigation accounted for 40 percent of freshwater withdrawals in 2005 compared to 43 percent in 1975.

Fresh groundwater withdrawals have increased steadily between 1950 and 2005, peaking in 2000 (fig. 38 and table 13). This long-term trend is a result of many factors, the most prominent being the availability of large quantities of highquality freshwater underlying most areas of the State coupled with the ability to pump large volumes of water economically from deep wells. In addition, increases in demand posed by population growth, tourism, and crop irrigation have also made groundwater more important over the past 50 years. Groundwater has been the primary source of freshwater in Florida between 1980 and 2005, supplying about 60 percent of total freshwater withdrawals. More recently, groundwater withdrawals have fluctuated somewhat (fig. 38), as demands change due to rainfall, water conservation and restrictions, and the use of reclaimed wastewater.

Fresh surface-water withdrawals increased dramatically between 1950 and 1975, peaking in 1965 (fig. 38 and table 13). More recently, fresh surface-water withdrawals have remained fairly constant with some minor fluctuations between 1980 and 2005 (fig. 38 and table 13). The early trend was a result of an increase in power generation, because many new facilities were built in the 1950s and 1960s along with the draining of land for crop production in southern Florida. Through a series of canals, levees, and pump stations built between the 1950s and 1960s, surface water became available to irrigate thousands of acres of vegetables and sugarcane (Renken and others, 2005). Between 1950 and 1970, power generation accounted for 65 to 80 percent of the fresh surfacewater withdrawals. During the 1970s and into the 1980s many powerplants were built along the coast so they could use saline surface water; more recently, most powerplants became 


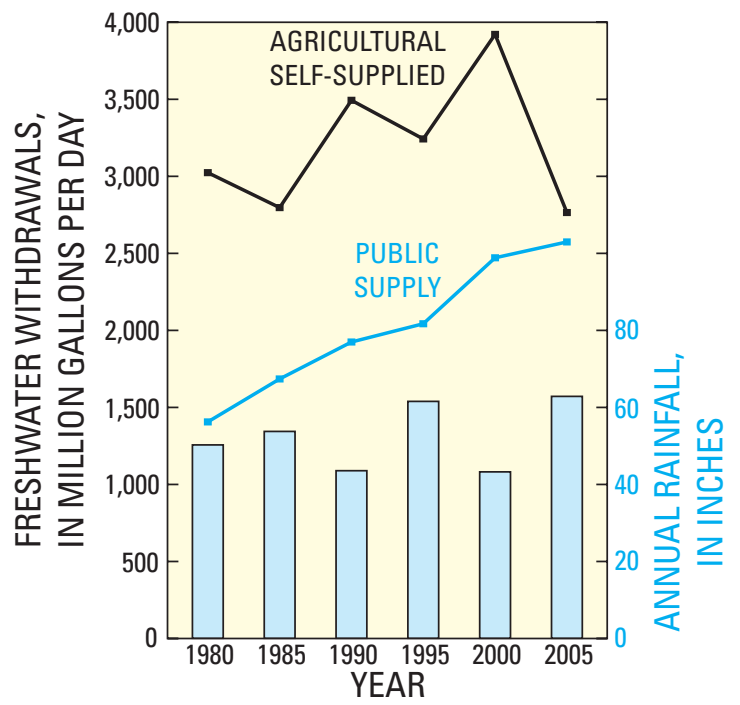

Figure 36. Freshwater withdrawals for agricultural self-supplied and public supply with statewide average annual rainfall in Florida, 1980-2005. From Marella (2004) and U.S. Department of Commerce (2008).

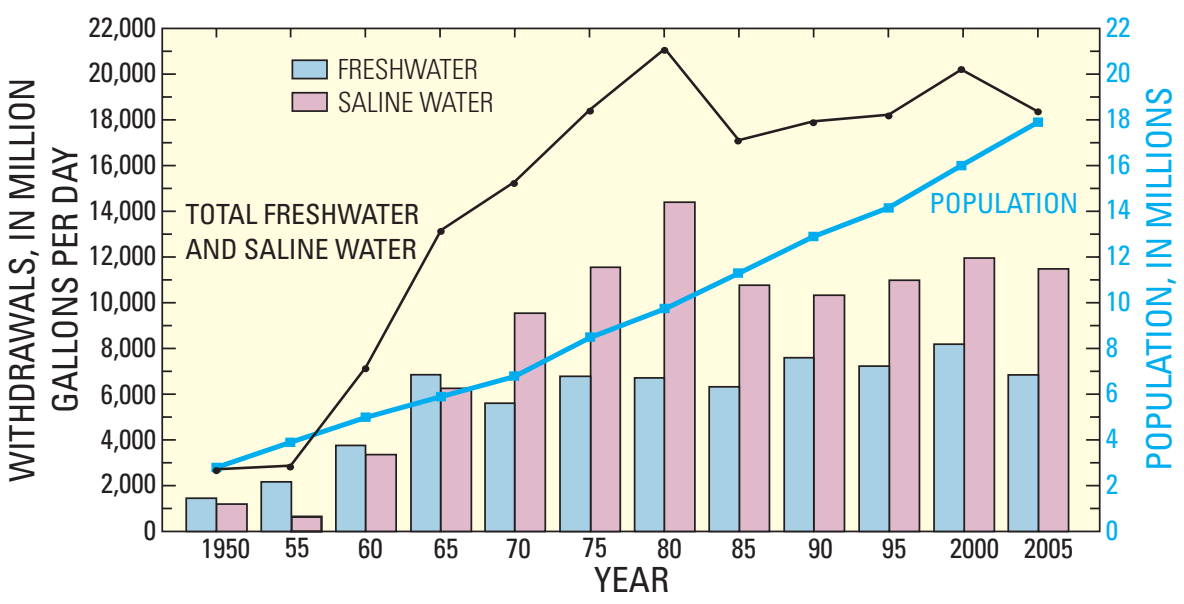

Figure 37. Historical total population, freshwater, and saline-water withdrawals in Florida, 1950-2005. Modified from Dietrich (1978), Marella (2004), and University of Florida (2006).

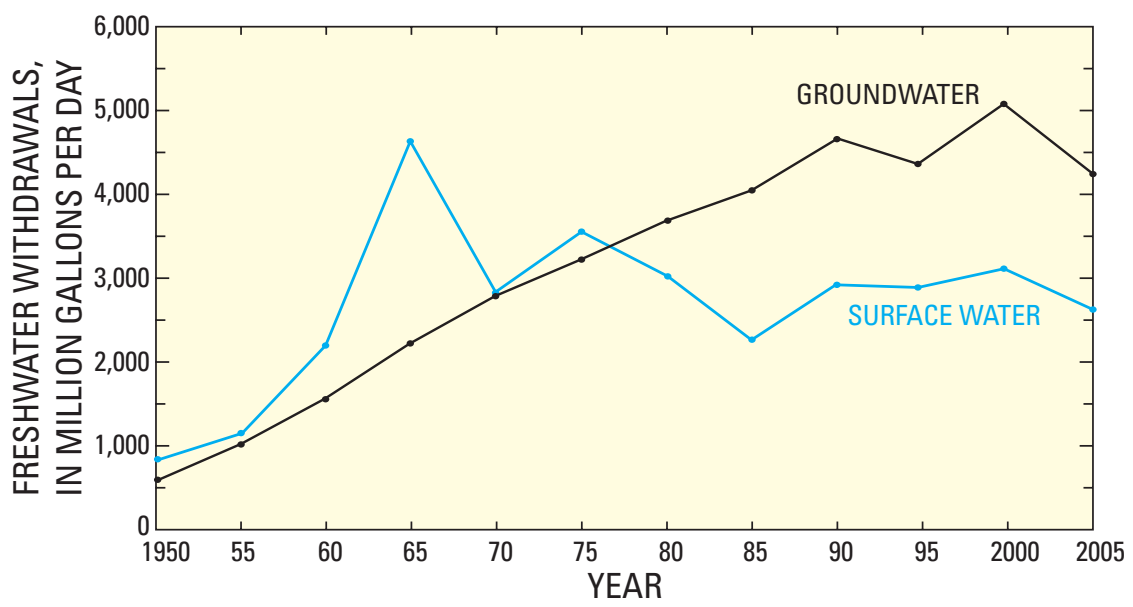

Figure 38. Historical freshwater withdrawals in Florida by source, 1950-2005. Modified from Marella (2004). 
Table 13. Historical population and water withdrawals in Florida by source, 1950-2005.

[Source: U.S. Geological Survey, Florida Water Science Center - Tallahassee; water values in million gallons per day; N/A, data not available]

\begin{tabular}{|c|c|c|c|c|c|c|c|c|c|}
\hline \multirow{2}{*}{ Year } & \multicolumn{2}{|c|}{$\begin{array}{l}\text { Population } \\
\text { (in millions) }\end{array}$} & \multicolumn{5}{|c|}{ Water withdrawals } & \multirow{2}{*}{$\begin{array}{c}\text { Nonpotable } \\
\text { water }^{(\mathrm{a})}\end{array}$} & \multirow{2}{*}{$\begin{array}{l}\text { Reclaimed } \\
\text { water }^{(b)}\end{array}$} \\
\hline & Total & $\begin{array}{c}\text { Served by } \\
\text { public supply }\end{array}$ & Ground & Surface & Total & $\begin{array}{c}\text { Saline water } \\
\text { Total }\end{array}$ & Total water & & \\
\hline 1950 & 2.77 & 1.66 & 614.0 & (c) 840.0 & $1,454.0$ & (c) $1,200.0$ & $2,654.0$ & & \\
\hline 1960 & 4.95 & 3.37 & $1,560.0$ & $2,200.0$ & $3,760.0$ & $3,360.0$ & $7,120.0$ & - & - \\
\hline 1965 & 5.87 & 4.81 & $2,218.5$ & $4,633.5$ & $6,852.0$ & $6,261.0$ & $13,113.0$ & - & - \\
\hline 1970 & 6.79 & 5.42 & $2,786.7$ & $2,825.6$ & $5,612.3$ & $9,545.0$ & $15,157.3$ & 1.6 & N/A \\
\hline 1980 & 9.75 & 7.79 & $3,677.2$ & $3,024.0$ & $6,701.2$ & $13,897.0$ & $20,598.2$ & 2.5 & N/A \\
\hline 1985 & 11.32 & 9.74 & $4,047.7$ & $2,265.7$ & $6,313.4$ & $10,798.3$ & $17,111.7$ & 17.3 & 206.0 \\
\hline 1990 & 12.94 & 11.23 & $4,664.7$ & $2,918.9$ & $7,583.6$ & $10,366.1$ & $17,949.7$ & 47.9 & 266.0 \\
\hline 1995 & 14.15 & 12.21 & $4,348.8$ & $2,881.1$ & $7,229.9$ & $10,965.7$ & $18,195.6$ & 57.9 & 402.0 \\
\hline 2000 & 15.98 & 14.03 & $5,078.7$ & $3,113.1$ & $8,191.8$ & $11,955.8$ & $20,147.6$ & 95.3 & 575.0 \\
\hline 2005 & 17.92 & 16.13 & $4,247.3$ & $2,625.8$ & $6,873.1$ & $11,485.6$ & $18,358.7$ & 141.7 & 659.7 \\
\hline
\end{tabular}

(a) Nonpotable water includes water treated through desalination or diluted with fresher water to meet secondary drinking standards.

(b) Reclaimed wastewater includes all water reported by Florida Department of Environmental Protection as all types of reuse and wastewater disposal.

(c) Data for 1950 did not show freshwater or saline surface-water totals, values shown are estimated.

Data sources; Population

1950-1970 - University of Florida (Dietrich, 1978).

1975-2005 - Florida Statistical Abstract and United States Statistical Abstracts.

Data sources; Population served and water withdrawals (WRIR, Water-Resources Investigations Report; SIR, Scientific Investigations Report)

1950 - Modified from USGS Circular 115 (MacKichan, 1951).

1955 - Modified from USGS Circular 398 (MacKichan, 1957).

1960 - Modified from USGS Circular 456 (MacKichan and Kammerer, 1961).

1965 - Modified from USGS Circular 556 (Murray, 1968).

1970 - Modified from USGS Circular 676 (Murray and Reeves, 1972).

1975 - USGS WRIR 78-17 (Leach, 1978).

1977 - USGS WRIR 79-112 (Leach and Healy, 1980).

1980 - USGS WRIR 82-4090 (Leach, 1983).

1985 - USGS WRIR 88-4103 (Marella, 1988).

1990 - USGS WRIR 92-4140 (Marella, 1992).

1995 - USGS WRIR 99-4002 (Marella, 1999).

2000 - USGS SIR 2004-5151 (Marella, 2004).

Data sources; Reclaimed water

1985-2005 - 2005 Reuse Inventory (Florida Department of Environmental Protection, 2006) 
more water efficient or only withdrew water to augment losses for cooling ponds or towers. Surface water was the primary source of freshwater in Florida, supplying more than one-half of the total freshwater withdrawals between 1950 and 1975. Since 1980, however, surface water supplies about 40 percent of the State's freshwater withdrawals. In 2005, withdrawals for irrigation accounted for about 55 percent of the total fresh surface-water withdrawals, compared to power generation at 20 percent.

Total public-supply freshwater withdrawals increased 1,416 Mgal/d (126 percent) between 1975 and 2005, and increased $104 \mathrm{Mgal} / \mathrm{d}$ (4 percent) in the 5 years between 2000 and 2005 (fig. 39 and table 14). Total population served by public supply increased by 9.32 million (137 percent) between 1975 and 2005, and increased by 2.10 million (15 percent) between 2000 and 2005 (table 13). Increases in public-supply withdrawals are a result of population growth and tourism during this time, along with higher demands from commercial and industrial facilities that obtain water from public-supply water systems. Deliveries of public-supply water to commercial-industrial users increased $426 \mathrm{Mgal} / \mathrm{d}$ (258 percent) between 1975 (Leach, 1978) and 2005 and $33 \mathrm{Mgal} / \mathrm{d}$ (6 percent) between 2000 and 2005.

Domestic self-supplied withdrawals have ranged from 190 to $300 \mathrm{Mgal} / \mathrm{d}$ between 1975 and 2005 (table 14). During this period, the domestic self-supplied population in Florida has remained about 2 million people (table 13). Between 1995 and 2000, the method used to calculate the domestic selfsupplied withdrawals changed, because the domestic per capita was used in most counties for 2000 and 2005 compared to the public-supply gross per capita in prior years (see domestic selfsupplied section). All withdrawals for domestic self-supplied are assumed to be from groundwater sources.
Freshwater withdrawals for commercial-industrial self-supplied use decreased $394 \mathrm{Mgal} / \mathrm{d}$ (45 percent) between 1975 and 2005, and $101 \mathrm{Mgal} / \mathrm{d}$ (18 percent) between 2000 and 2005 (fig. 39 and table 14). Commercial-industrial selfsupplied withdrawals decreased because of a decline in manufacturing in Florida, as evident by the closure of several large paper mills, phosphate mines, and other manufacturing facilities over the past 15 years. In addition, many self-supplied commercial and industrial users switched to using public supply as a water source, whereas other self-supplied facilities became more efficient or recirculated water (primarily to lower their discharge amount). Most new commercial users obtain their water from a public supplier.

Freshwater withdrawals for agricultural self-supplied decreased $164 \mathrm{Mgal} / \mathrm{d}$ (6 percent) between 1975 and 2005, and 1,157 Mgal/d (30 percent) between 2000 and 2005 (fig. 39 and table 14). Agricultural withdrawals vary due to fluctuations in rainfall and acres irrigated. Statewide average annual rainfall varied by nearly $20 \mathrm{in}$. over six compilations in the past 30 years, and these fluctuations in rainfall dramatically affected irrigation demands between 1975 and 2005 (fig. 36). Irrigated acreage decreased by 3 percent between 1975 and 2005, and 38 percent of the acres irrigated in 2005 used more efficient irrigation systems compared to 16 percent 30 years ago. In addition, long-term withdrawals have decreased because of improved conservation measures, better management practices, and long-term water restrictions.

Freshwater withdrawals for recreational irrigation increased $148 \mathrm{Mgal} / \mathrm{d}$ (82 percent) between 1985 and 2005 (fig. 39 and table 14). Golf-course irrigation is the largest user of water in this category, and irrigated golf-course acreage increased by 0.043 million acres ( 57 percent) between 1985 and 2005. More recently, withdrawals for recreational irrigation decreased $82 \mathrm{Mgal} / \mathrm{d}$ (20 percent) between 2000 and 2005,

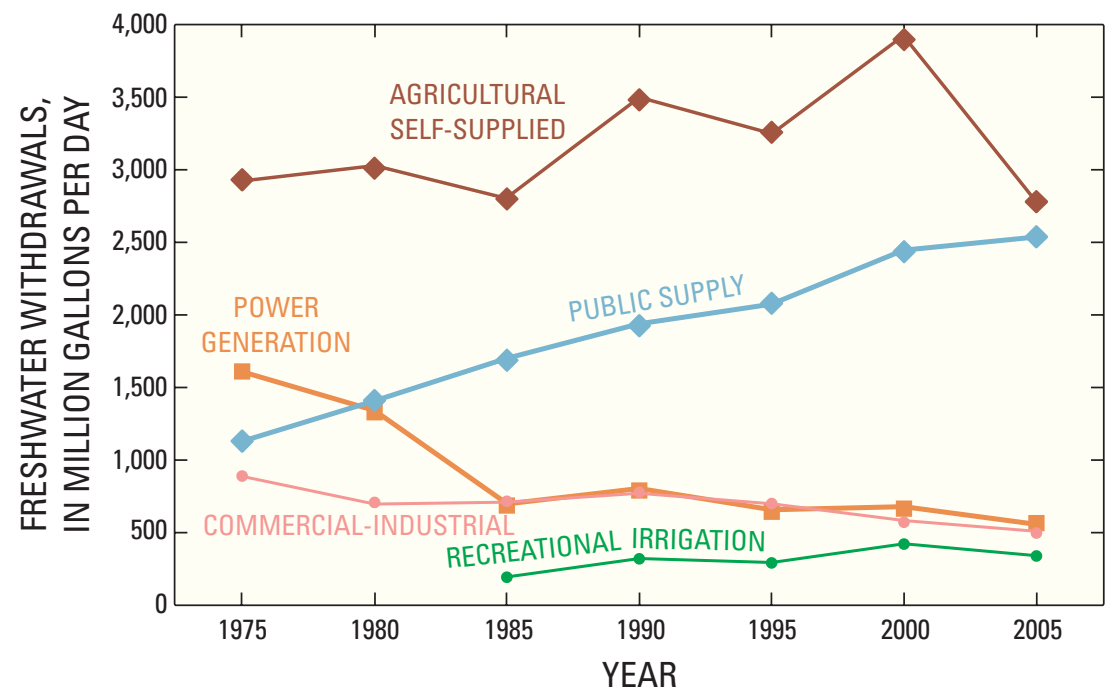

Figure 39. Historical freshwater withdrawals in Florida by category, 1975-2005. Modified from Marella (2004). 
Table 14. Historical freshwater withdrawals in Florida by category, 1970-2005.

[Source: U.S. Geological Survey, Florida Water Science Center - Tallahassee; all values in million gallons per day; - , no data available or partial data only; N/A, totals not available]

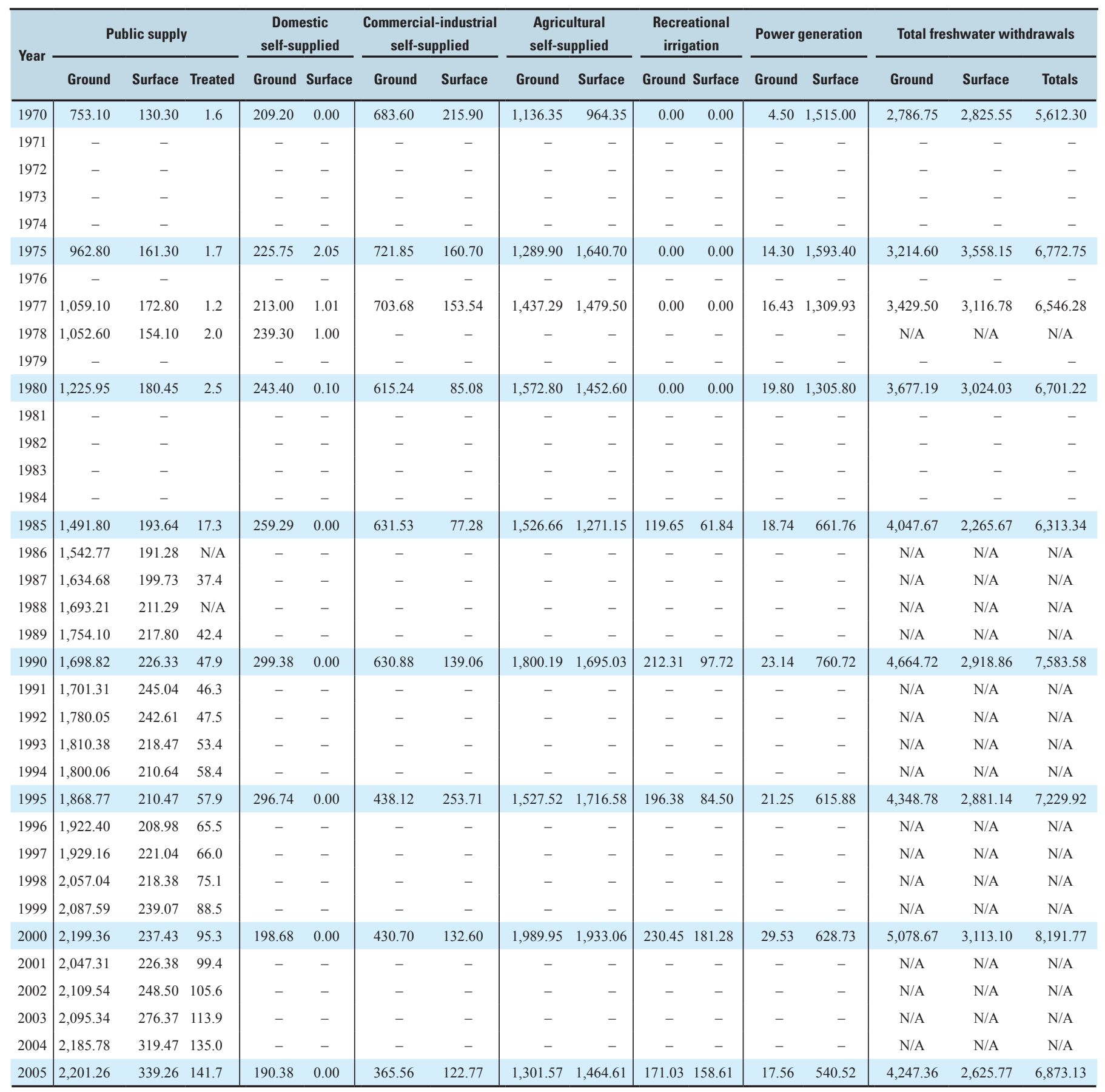

Values for 2005 presented in this table may differ from those published earlier for 2005 due to changes in data. These values represent the most current State totals for 2005 . Public-supply treated water includes brackish water treated through a desalination process or diluted with fresher water to meet public drinking-water standards.

The estimation procedure for domestic self-supplied withdrawals changed for 2000, as a different per capita was used to calculate withdrawals compared to previous years. Agricultural self-supplied includes water withdrawn for crop irrigation, livestock, and fish farming purposes.

Recreational irrigation includes water used for all turf grasses (golf, commercial, industrial, and public). This category was accounted for under Agricultural self-supplied from 1965 through 1984

Data sources;

1970 - 2000 - USGS Scientific Investigations Report 2004-5151 (Marella, 2004).

2001 - 2004 - USGS unpublished water-use data files, Tallahassee, Florida. 
but irrigated golf-course acreage remained nearly the same. Most of this recent decrease is a result of additional rainfall during 2005 and an increase in the use of reclaimed water for golf-course irrigation. Golf-course data were included under agricultural irrigation prior to 1985 .

Freshwater withdrawals for power generation decreased 1,050 Mgal/d (65 percent) between 1975 and 2005, and $100 \mathrm{Mgal} / \mathrm{d}$ (15 percent) between 2000 and 2005 (fig. 39 and table 14). This decrease was due to an increase in water efficiency and the recycling of cooling water after routing the water to cooling ponds or cooling towers (Hughes, 1975). Between 1975 and 2005, gross power generated in Florida increased by $122,700 \mathrm{GWh}$ (151 percent) and by 35,000 GWh (20 percent) between 2000 and 2005.

The use of nonpotable groundwater as a source of supply, primarily for public supply, also has increased in Florida. Nonpotable is defined as water that does not meet drinkingwater standards set by FDEP and, therefore, needs some form of treatment or dilution to meet set standards. The amount of nonpotable water treated to meet drinking-water standards increased from just under $2 \mathrm{Mgal} / \mathrm{d}$ in 1970 , to $142 \mathrm{Mgal} / \mathrm{d}$ in 2005 (tables 13 and 14). Several public-supply water systems depend solely on nonpotable treated water, but most water systems use nonpotable water to augment their existing sources. Most of this nonpotable water use is located along the east and west coast of central and south Florida and is obtained from groundwater sources.

Reclaimed wastewater is water treated by a domestic or industrial wastewater-treatment facility and made available for use again. The use of reclaimed wastewater increased from $206 \mathrm{Mgal} / \mathrm{d}$ in 1986 to nearly $660 \mathrm{Mgal} / \mathrm{d}$ in 2005 (Florida Department of Environmental Protection, 2006) (table 13).

Approximately one-half (331 Mgal/d) of the reclaimed wastewater flow in 2005 was used to reduce potable-quality water withdrawals for urban irrigation, agricultural irrigation, and industrial use, but one-third (220 Mgal/d) of the reclaimed wastewater was returned to available water supplies as aquifer recharge (Gregory M. Brown, FDEP, written commun., 2008). The use of reclaimed water is expected to continue to increase statewide (Florida Department of Environmental Protection, 2006).

Many factors that affect water demands in Florida are detailed in this report (climate, economics, population growth, tourism and others), as well as many factors not mentioned (social-economic factors, such as household size, age, income, and age of resident, among others). All of these factors affect saline and freshwater demands during a given period. However, it is difficult to determine or measure the effects of any one of them individually. Therefore, it is assumed that these factors have a cumulative effect on current and historical water use in Florida and vary from year to year.

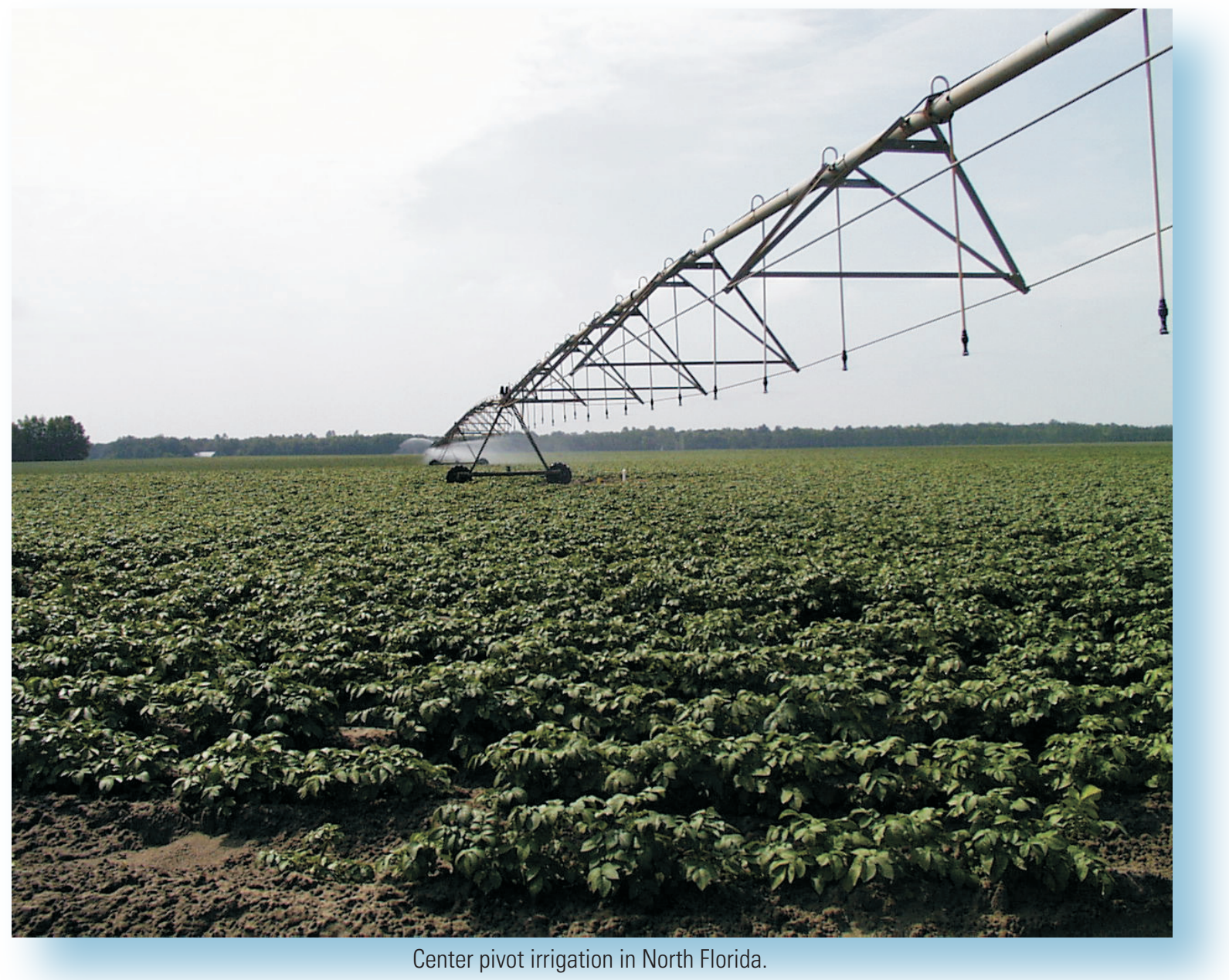




\section{Selected References}

American Water Works Association, 1992, Water industry data base: utility profiles: Denver, Colo., American Water Works Association, $80 \mathrm{p}$.

Bucca, Jane, and Marella, R.L., 1992, An improved method for determining the nonresidential water use component of total public water supply estimates, in Jones, M.E., and Laenen, Antonius (eds.), Interdisciplinary approaches in hydrology and hydrogeology: American Institute of Hydrology, p. 511-523.

Buros, O.K., 1989, Desalting practices in the United States: American Water Works Association Journal, v. 81, no. 11, p. $38-42$.

Campbell, K.M., 1986, The industrial minerals of Florida: Tallahassee, Florida Bureau of Geology Information Circular 102, 94 p.

Davis, W.Y., Rodrigo, D.M., Opitz, E.M., and others, 1988, IWR-Main water use forecasting system, version 5.1: Users manual and system description: Fort Belvoir, Va., U.S. Army Corps of Engineers, Institute for Water Resources, IWR-Main Report 88-R-6, 273 p.

Dietrich, T.S., 1978, The urbanization of Florida's population: An historical perspective of county growth 1830-1970: Gainesville, University of Florida, College of Business Administration, Bureau of Economic and Business Research, $211 \mathrm{p}$.

Duerr, A.D., Hunn, J.D., Lewelling, B.R., and Trommer, J.T., 1988, Geohydrology and 1985 water withdrawals of the aquifer systems in southwest Florida, with emphasis on the intermediate aquifer system: U.S. Geological Survey WaterResources Investigations 87-4259, 115 p.

Dykes, G.M., and Conlon, W.J., 1989, Use of membrane technology in Florida: American Water Works Association Journal, v. 81, no. 11, p. 43-46.

Fernald, E.A., and Patton, D.J., eds., 1984, Water resource atlas of Florida: Tallahassee, Florida State University, Institute of Science and Public Affairs, 291 p.

Fernald, E.A., and Purdum, E.D., eds., 1992, Atlas of Florida: Tallahassee, Florida State University, Institute of Science and Public Affairs, 280 p.

Fernald, E.A., and Purdum, E.D., eds., 1998, Water resource atlas of Florida: Tallahassee, Florida State University, Institute of Science and Public Affairs, $312 \mathrm{p}$.

Florida Agricultural Statistics Service, 2007, Commercial citrus inventory 2006: Orlando, Florida Agricultural Statistics Service, Florida Department of Agriculture and Consumer Services, $81 \mathrm{p}$.
Florida Department of Agriculture and Consumer Services, 2006, Florida Agriculture Statistical Directory 2006: Tallahassee, Division of Marketing and Development August, 2006, 174 p.

Florida Department of Environmental Regulation, 1990, Drinking water standards, monitoring, and reporting: Tallahassee, chap. 17-550, 48 p.

Florida Department of Environmental Regulation, 1991, Domestic wastewater facilities: Tallahassee, chap. 17-600, 70 p.

Florida Department of Environmental Protection, 2006, 2005 Reuse inventory: Tallahassee, Water Reuse Program, 21 p.

Hodges, A.W., Haydu, J.J., van Blokland, P.J., and Bell, A.P., 1994, Contribution of the turf grass industry to Florida's economy, 1991/92: A value added approach: Gainesville, University of Florida, Institute of Food and Agricultural Sciences, Food and Resource Economics Department, Economic Report ER94-1, 83 p.

Hughes, G.H., 1975, Perspective on use of freshwater for cooling systems of thermoelectric power plants in Florida: U.S. Geological Survey Water-Resources Investigations 43-75, 30 p.

Hutson, S.S., Barber, N.L., Kenny, J.F., and others, 2004, Estimated use of water in the United States in 2000: Reston, Va., U.S. Geological Survey Circular 1268, 46 p.

Hutson, S.S., 2007, Guidelines for preparation of state water-use estimates for 2005: Reston, Va., U.S. Geological Survey, Office of Ground Water, Techniques and Methods, book 4, chap. E1, 28 p.

Izuno, F.T., and Haman, D.Z., 1987, Basic irrigation terminology: Gainesville, University of Florida, Institute of Food and Agricultural Sciences, Agricultural Engineering Fact Sheet AE-66, 4 p.

Jones, J.W., Allen, L.H., Shih, S.F., and others, 1984, Estimated and measured evapotranspiration for Florida climate, crops, and soils: Gainesville, University of Florida, Institute of Food and Agricultural Sciences, Bulletin 840 (technical), 65 p.

Kenny, J.F., Barber, N.L., Hutson, S.S., Linsey, K.S., Lovelace, J.K., and Maupin, M.A., 2009, Estimated use of water in the United States in 2005: U.S. Geological Survey Circular 1344, $52 \mathrm{p}$.

Knowles, Leel, Jr., O’Reilly, A.M., and Adamski, J.C., 2002, Hydrogeology and simulated effects of ground-water withdrawals from the Floridan aquifer system in Lake County and in the Ocala National Forest and vicinity, north-central Florida: U.S. Geological Survey Water-Resources Investigations $02-4207,140 \mathrm{p}$. 
Leach, S.D., 1978, Source, use, and disposition of water in Florida, 1975: U.S. Geological Survey Water-Resources Investigations 78-17, $90 \mathrm{p}$.

Leach, S.D., 1983, Source, use, and disposition of water in Florida, 1980: U.S. Geological Survey Water-Resources Investigations 82-4090, $337 \mathrm{p}$.

Leach, S.D., and Healy, H.G., 1980, Estimated water use in Florida, 1977: U.S. Geological Survey Water-Resources Investigations Report 79-112, 76 p.

Lovelace, J.K., 2009a, Method for estimating water withdrawals for livestock in the United States, 2005: U.S. Geological Survey Scientific Investigations Report 2009-5041, 7 p.

Lovelace, J.K., 2009b, Methods of estimating water withdrawals for aquaculture in the United States, 2005: U.S. Geological Survey Scientific Investigations Report 2009-5042, 13 p.

MacKichan, K.A., 1951, Estimated use of water in the United States, 1950: U.S. Geological Survey Circular 115, 13 p.

MacKichan, K.A., 1957, Estimated use of water in the United States, 1955, U.S. Geological Survey Circular 398, 18 p.

MacKichan, K.A., and Kammerer, J.C., 1961, Estimated use of water in the United States, 1960: U.S. Geological Survey Circular 456, 44 p.

Marella, R.L., 1988, Water withdrawals, use, and trends in Florida, 1985: U.S. Geological Survey Water-Resources Investigations Report 88-4103, 43 p.

Marella, R.L., 1992, Water withdrawals, use, and trends in Florida, 1990: U.S. Geological Survey Water-Resources Investigations Report 92-4140, 38 p.

Marella, R.L., 1993, Public-supply water use in Florida, 1990: U.S. Geological Survey Open-File Report 93-134, 46 p.

Marella, R.L., 1994, Estimated discharge of treated wastewater in Florida, 1990: U.S. Geological Survey Open-File Report 93-364, 53 p.

Marella, R.L., 1997, Irrigated crop acreage and water withdrawals in Florida, 1990: Florida Department of Environmental Protection, Tallahassee, Florida Geological Survey, Map Series 143, 1 sheet.

Marella, R.L., 1999, Water withdrawals, use, discharge, and tends in Florida,1995: U.S. Geological Survey, WaterResources Investigations Report 99-4002, 90 p.

Marella, R.L., 2004, Water withdrawals, use, discharge, and trends in Florida, 2000: U.S. Geological Survey, Scientific Investigations Report 2004-5151, 136 p.

Marella, R.L., 2008, Water use in Florida, 2005 and trends 19502005: U.S. Geological Survey, Fact Sheet 2008-3080, 6 p.
McPherson, B.F., and Hammett, K.M., 1991, Tidal rivers of Florida, in Livingston, R.J., ed., The rivers of Florida: New York, Springer-Verlag Incorporated, Ecological Studies 83, p. 31-46.

Miller, J.A., 1990, Ground water atlas of the United States, Segment 6, Alabama, Florida, Georgia, and South Carolina: U.S. Geological Survey Hydrologic Investigation Atlas 730-G, 28 p.

Murray, C.R., 1968, Estimated use of water in the United States, 1965: U.S. Geological Survey Circular 556, 53 p.

Murray, C.R., and Reeves, E.B., 1972, Estimated use of water in the United States, 1970: U.S. Geological Survey Circular $676,37 \mathrm{p}$.

Murray, C.R., and Reeves, E.B., 1977, Estimated use of water in the United States, 1975: U.S. Geological Survey Circular $765,37 \mathrm{p}$.

National Golf Foundation, 2006, Golf course directory-2006 Edition: Jupiter, Fla., v. I, Alabama-Idaho, 414 p.

Orlando Business Journal, 2006, Record number of visitors came to Florida in 2005: Orlando, Fla., February 27, 2006, 1 p.

Pride, R.W., 1973, Estimated use of water in Florida, 1970: Tallahassee, Florida Bureau of Geology Information Circu$\operatorname{lar} 83,31 \mathrm{p}$.

Pride, R.W., 1975, Estimated water use in Florida, 1965 (2d ed.): Tallahassee, Florida Bureau of Geology Map Series 36, 1 sheet.

Reese, R.S., 2006, Review of aquifer storage and recovery performance in the Upper Floridan aquifer in southern Florida: U.S. Geological Survey Fact Sheet 2006-3126, 2 p.

Renken, R.A., 1998, Ground water atlas of the United States, Segment 5, Arkansas, Louisiana, Mississippi: U.S. Geological Survey Hydrologic Investigation Atlas 730-F, 28 p.

Renken, R.A., Dixon, Joann, Koehmstedt, John, and others, 2005, Impact of anthropogenic development on coast ground-water hydrology in southern Florida, 1900-2000: Reston, Va., U.S. Geological Survey Circular 1275, 77 p.

St. Johns River Water Management District, 2006, Annual water use data, 2005: Palatka, Fla., St. Johns River Water Management District Technical Fact Sheet SJ2006-FS2 14 p.

Seaber, P.R., Kapinos, F.P., and Knapp, G.L., 1984, State hydrologic unit maps: U.S. Geological Survey Open-File Report 84-708, 63 p.

Sepulveda, Nicasio, 2002, Simulation of ground-water flow in the intermediate and Floridan aquifer systems in peninsular Florida: U.S. Geological Survey Water-Resources Investigations $02-4009,130 \mathrm{p}$. 
Shoemaker, W.B., and Edwards, K.M., 2003, Potential for saltwater intrusion into the lower Tamiami aquifer near Bonita Springs, southwestern Florida: U.S. Geological Survey Water-Resources Investigations 03-4262, 74 p.

Smajstrla, A.G., 1986, Agricultural field scale irrigation requirements simulation model: Technical manual: Gainesville, University of Florida, Agricultural Engineering Department, $52 \mathrm{p}$.

Smajstrla, A.G., Boman, B.J., Clark, G.A., and others, 1988, Efficiencies of Florida agricultural irrigation systems: Gainesville, University of Florida, Institute of Food and Agricultural Sciences, Bulletin 247, 15 p.

Smajstrla, A.G., and others, 1993, Microirrigation in Florida: Systems, acreage and cost: Gainesville, University of Florida, Institute of Food and Agricultural Sciences, Bulletin $276,12 \mathrm{p}$.

Smith, S.K., and Cody, Scott, 2006, Number of households and average household size in Florida: April 1, 2005: Gainesville, University of Florida, Bureau of Economic and Business Research, v. 39, Bulletin 143, 4 p.

Smith, S.K., and Rayer, Stefan, 2007, Projections of Florida population by county 2006-2030: Gainesville, University of Florida, Bureau of Economic and Business Research, v. 40, Bulletin 147, 8 p.

Solley, W.B., Chase, E.B., and Mann, W.B., 1983, Estimated use of water in the United States in 1980: U.S. Geological Survey Circular 1001, 56 p.

Solley, W.B., Merk, C.F., and Pierce, R.R., 1988, Estimated use of water in the United States in 1985: U.S. Geological Survey Circular 1004, 82 p.

Solley, W.B., Pierce, R.R., and Perlman, H.A., 1993, Estimated use of water in the United States in 1990: U.S. Geological Survey Circular 1081, 76 p.

Solley, W.B., Pierce, R.R., and Perlman, H.A., 1998, Estimated use of water in the United States in 1995: U.S. Geological Survey Circular 1200, 78 p.

South Florida Water Management District, 1990, Desalination: An additional water source for south Florida: West Palm Beach, Office of Communications, (PIO 276290 5M), 4 p.

Southwest Florida Water Management District, 2007, 2005 Estimated water use in the Southwest Florida Water Management District: Brooksville, Resource Conservation and Development Department, Conservation Projects Section, 223 p.

Tampa Bay Water, 2008, Tampa Bay Water Works 2008 Annual Report: Clearwater, 8 p.
U.S. Census Bureau, 1993, 1990 Census of housing, detailed housing characteristics: Florida: Washington, D.C., U.S. Department of Commerce, Bureau of the Census, Ch-2-11, 793 p.

U.S. Census Bureau, 2006a, Statistical abstract of the United States 2007 (126d ed.): Washington D.C., U.S. Department of Commerce, Bureau of the Census, 999 p. Accessed at http://www.census.gov/statab/www

U.S. Census Bureau, 2006b, County business patterns, 2004, Florida: Washington D.C., U.S. Department of Commerce, Bureau of the Census, CBP-04-11, 369 p.

U.S. Department of Agriculture, 2004, 2002 Census of Agriculture-Florida state and county data: Washington D.C., U.S. Department of Agriculture, National Agricultural Statistics Service, Geographic Area Series, Part 9 (AC 02-A-9), v. 1, 485 p.

U.S. Department of Commerce, 2008, National Climatic Data Center - Climate data online: National Oceanic and Atmospheric Administration. Accessed May 21, 2008 at http://cdo.ncdc.noaa.gov/CDO/cdo\#TOP

U.S. Geological Survey, 1975, State of Florida, Hydrologic unit map, 1974: U.S. Geological Survey, 1 sheet, scale $1: 500,000$.

U.S. Soil Conservation Service, 1970, Irrigation water requirement (revised): U.S. Department of Agriculture Technical Release 21, $88 \mathrm{p}$.

U.S. Soil Conservation Service, 1982, Florida irrigation guide: Gainesville, U.S. Department of Agriculture, Soil Conservation Service, 300 p.

University of Florida, 2006, Florida Estimates of Population, 2005: Gainesville, University of Florida, Bureau of Economic and Business Research, 59 p.

Vecchioli, John, and Foose, D.W., 1985, Florida ground-water resources, in The national water summary, 1984-Hydrologic events, selected water quality trends and ground-water resources: U.S. Geological Survey Water-Supply Paper 2275, p. 173-178.

Verdi, R.J., Tomlinson, S.A., and Marella, R.L., 2006, The drought of 1998-2002: Impacts of Florida's hydrology and landscape: U.S. Geological Survey Circular 1295, $34 \mathrm{p}$.

White, J.K., and van Blokland, P.J., 2006, Trends in Florida citrus with emphasis on Indian River, St. Lucie, Martin, and Palm Beach Counties: Gainesville, University of Florida, Food and Resource Economics Department, EDIS FE636, 9 p. 


\section{Glossary}

\section{A}

Advanced wastewater treatment Any treatment of sewage that goes beyond the secondary or biological water treatment stage and includes the removal of nutrients, such as phosphorus and nitrogen and a high percentage of suspended solids. This treatment is more stringent than secondary treatment, and requires an 85 percent reduction in conventional pollutant concentrations or a significant reduction in nonconventional pollutants (U.S. Environmental Protection Agency, 1997, written commun.).

Agriculture water use Includes water used for agricultural irrigation and nonirrigation purposes. Irrigation water use includes the artificial application of water on lands to assist in the growing of crops, plants, and pasture. Nonirrigation water use includes water used for livestock, fish farming, and other farm needs. Livestock water use includes water used for stock watering, feedlots, and dairy operations. The water can be obtained from a public supply or be self-supplied.

\section{C}

Commercial water use Water for motels, hotels, restaurants, office buildings, commercial facilities and civilian and military institutions. The water may be obtained from a public supply or be self supplied.

Community water system A public water system which serves at least 15 service connections used by year-round residents or regularly serves at least 25 year-round residents (Florida Department of Environmental Regulation, 1990).

Consumptive use That part of water withdrawn that is evaporated, transpired, incorporated into products or crops, consumed by humans or livestock, or otherwise removed from the immediate water environment. Sometimes called water consumed or water depleted.

Cooling pond Usually a manmade water body used by power plants or large industrial plants that enables the facility to recirculate once-through cooling water. The water levels in the pond are usually maintained by rainfall or augmented by pumping (withdrawal of) water from another source (fresh, saline, or reclaimed).

Cooling tower A large tower or stack that is used for heat exchange of once-through cooling water generated by steam condensers. Hot water from the plant is sprayed into the top of the tower and exchanges heat with the passing air as it falls. The water is then collected at the bottom of the tower and used again. A small amount of water is lost (consumed) through evaporation in this process. See cooling water or once-through cooling.

Cooling water Water used for cooling purposes by electric generators, steam condensers, large machinery or products at power or industrial plants. Water used for cooling purposes can be either fresh, saline, or reclaimed and may be used only once or recirculated multiple times. See cooling pond or once-through cooling water.

\section{D}

Desalination The removal of salts from highly mineralized water. Desalination is primarily used for public-supply water to ensure that it meets Florida Department of Environmental Protection secondary drinking standards. The primary types of desalination used in Florida are: (1) distillation, (2) electrodialysis processes, and (3) reverse osmosis processes (Buros, 1989, South Florida Water Management District, 1990). The reverse osmosis processes are the most commonly used in Florida followed by electrodialysis (Dykes and Conlon, 1989). In addition to these three desalination processes, many public suppliers also dilute or blend nonpotable or brackish water with fresher water to produce potable water. Also see reverse osmosis.

Dewatering The deliberate attempt to lower the ground-water level in or below land surface for selected purposes such as agricultural, construction, mining or other activities. For mining operation, dewatering usually is accomplished by pumping the water 
out of the ground and discharging to a surfacewater body. However, some dewatering involves gravity feeding water from the surficial aquifer into a deeper aquifer (usually the Floridan aquifer system) through recharge wells (Campbell, 1986).

Domestic wastewater facility Facilities that receive or dispose of wastewater derived principally from residential dwellings, business or commercial buildings, institutions, and other facilities (Florida Department of Environmental Regulation, 1991). Can also include some waste-water derived from industrial facilities. May also be referred to as a municipal wastewater facility.

Domestic water use Water for normal household purposes, such as drinking, food preparation, bathing, washing clothes and dishes, flushing toilets, and other indoor uses. It also includes outdoor uses, such as car washing and watering household lawns and gardens. Also called residential water use. The water can be obtained from a public supply or be self supplied.

E

Effluent Water that flows out of a wastewater treatment facility or septic tanks that are used for the purpose of treating, stabilizing, or holding waste.

$\mathbf{F}$

Flood irrigation Irrigation systems that control the water table with lateral supply ditches. These include open field ditch systems (furrows), semi-closed conveyance systems, subsurface conduit systems, crown flood systems, and continuous flood systems. Also includes seepage or subsurface irrigation systems. The efficiencies of these flood irrigation systems range from 20 to 80 percent (Smajstrla and others, 1988); however, an average of 60 percent is commonly used for estimating water requirements. May also be referred to as subsurface irrigation.

Freshwater Water that contains less than 1,000 milligrams per liter $(\mathrm{mg} / \mathrm{L})$ of dissolved solids; generally, more than $500 \mathrm{mg} / \mathrm{L}$ is considered undesirable for drinking and many industrial uses. Generally, freshwater is considered potable.

G

Giga watt hour (GWh) A measure of electricity, one billion watthours.
Groundwater That part of the subsurface water that is in the saturated zone (a zone in which all voids are filled with water).

Groundwater disposal Wastewater that is disposed of through the ground either by injection or seepage. This includes the following discharge methods; absorption beds, injection wells, drainfields, percolation ponds, rapid infiltration basins, spray fields, and land application systems (Marella, 1994). Land application systems or reuse systems are considered a ground-water disposal as treated wastewater used to irrigate is generally intended to filter down through the soil.

H

Hydroelectric-power water use The use of water in the generation of electricity at plants where the turbine generators are driven by falling water. This is considered an instream use of water.

Industrial wastewater facility Facilities that produce, treat or dispose of wastewater not otherwise defined as a domestic wastewater; includes the runoff and leachate from areas that receive pollutants associated with industrial or commercial storage, handling, or processing (Florida Department of Environmental Regulation, 1991).

Industrial water use Water used for industrial purposes such as fabricating, processing, washing, and cooling, and includes such industries as steel, chemical and allied products, paper and allied products, mining, and petroleum refining. The water can be obtained from a public supply or be self-supplied.

Instream use Water use taking place within a stream channel for such purposes as hydroelectric power generation, navigation, water-quality improvement, fish and wildlife propagation, and recreation. Sometimes called non withdrawal use or in-channel use.

M

Micro irrigation Irrigation systems that apply water directly to, or very near, the soil surface, either above the ground or into the air, in discrete drops, continuous drops, small streams, mist, or sprays. These include drip systems, spray systems, jet systems, and bubbler systems. Also referred to as drip, low pressure or low volume irrigation. The efficiencies of these micro-irrigation systems 
range from 75 to 95 percent (Smajstrla and others, 1988, 1993), however, an average of 80 percent is commonly used for estimating water requirements.

Mining water use Water used for the extraction of minerals and liquids. Mining also includes water used for milling (such as crushing, screening, washing, and flotation), environmental purposes (such as dust control and wetland restoration or maintenance), material conveyance, dewatering, and domestic uses on the premises. Generally, most of the water used at a mining operation is self-supplied.

\section{N}

Navigational water use Water utilized as a means of commercial (and sometimes recreational) transportation. Includes water used to lift a vessel in a lock, or maintain a navigable channel level. Navigational water use is considered a no consumptive instream use of water and is generally not measured.

Net water use Water withdrawals plus or minus water transfers. In most counties, the net water use and water withdrawals are equal. However, in counties involved in water transfers (imports and exports), the net water use represents the actual amount of water used regardless of the amount of water withdrawn. In Florida, water transfers are mostly found in the public supply category. Also see water transfers.

Noncommunity water system A public water system which provides piped water for human consumption to at least 15 service connections or which serves at least 25 individuals at least 60 days out of the year but which is not a community water system. The difference between a community water system and a non-community water system is that the former serves inhabitants whereas the latter serves transients or non-residents who otherwise do not inhabit the building served by the system. (Florida Department of Environmental Regulation, 1990).

\section{Nontransient Noncommunity water}

system A public water system that is not a community water system and that regularly serves at least 25 of the same persons over a 6 month period. (Florida Department of Environmental Regulation, 1990).

Nonpotable water Water that is highly mineralized and needs some form of treatment before it meets standards set by the Florida Department of Environmental Protection and can be made available for human consumption. In Florida, chloride and dissolved-solids concentrations in potable water must be less than or equal to 250 and $500 \mathrm{mg} / \mathrm{L}$, respectively. Nonpotable water exceeds these concentrations consistently or periodically and is either diluted with fresher water or treated through a desalination or filtration process to meet potable-water standards for public supply (see desalination).

\section{0}

Once-through cooling water Water (fresh or saline) that is withdrawn from a river, stream or other water body (manmade or natural), or a well, that is passed through a steam condenser one time, and then returned to the river or stream or other water body some distance from the intake (Hughes, 1975). Once-through cooling water is used to exchange the heat from the steam condensers to the cooler water. This method of cooling is commonly used in power production throughout Florida, and usually results in no consumption.

Off stream use Water withdrawn or diverted from a ground- or surface-water source for public-water supply, industry, irrigation, livestock, thermoelectric power generation, and other uses. Sometimes called off-channel use or withdrawal use.

Other water use Water used in Florida for such purposes as heating, cooling, irrigation (public-supplied only), lake augmentation, and other nonspecific uses. The water can be obtained from a public supply or be self-supplied.

$\mathbf{P}$

Per capita use The average amount of water used per person during a standard time period, generally per day. For this report, two per capita's are calculated, public supply gross and domestic. Public supply gross per capita is the total public-supply water withdrawn divided by the total population served by public supply. Per capita water use computed in this manner includes water delivered for all uses of public supply water (domestic, commercial, industrial, public use and other uses). Public supply domestic per capita is calculated by dividing the deliveries to domestic use from public suppliers divided by the population served. Per capita computed in this manor represents the amount of water 
used at a household level (both indoor and outdoor) because it excludes all other uses of public supply water (commercial, industrial, public use, or other uses).

Potable water Water that meets the quality standards set by the Florida Department of Environmental Protection. Potable water is considered safe for human consumption and is often referred to as drinking water. In Florida, chloride and dissolved-solids concentrations in potable water must be less than or equal to 250 and $500 \mathrm{mg} / \mathrm{L}$, respectively. Freshwater that exceeds these chloride and dissolved solids limits is often referred to as nonpotable or brackish water and is either diluted with fresher water or treated through a desalination or filtration process to meet potable-water standards for public supply.

Power-generation water use Water used in the process of the generation of electric power through a thermoelectric or hydroelectric facility. The majority of water used for this category is for cooling purposes (much of which is used for once-through cooling). Water is also used for boiler makeup or domestic purposes throughout the plant. Boiler makeup water and water used for domestic purposes are generally obtained from public supply, however, for plants located in remote areas, this water can be self-supplied. Cooling water is generally selfsupplied, although some smaller plants use public-supply water for cooling purposes.

Primary wastewater treatment First step in wastewater treatment where screens and sedimentation tanks are used to remove most materials that float or settle. Primary treatment removes about 30 percent of carbonaceous biochemical oxygen demand from domestic sewage (U.S. Environmental Protection Agency, 1997, written commun.).

Public supply Water withdrawn by public or private water suppliers and delivered to users who do not supply their own water. Water suppliers provide water for a variety of uses, such as domestic, commercial, industrial, thermoelectric power (domestic and cooling purposes), and public water use. According to the Florida Department of Environmental Protection, any water system that serves more than 25 people or has 15 year-round service connections is considered a community public supplier (Florida Department of Environmental Regulation, 1990). For this report, public supply includes those systems that serve more than 400 people or use more than 10,000 gallons per day.

Public-water use Water supplied from a public-water supply and used for such purposes as firefighting, street washing, and municipal parks and swimming pools. Publicwater use also includes system losses during distribution, processing (including discharged from desalination or lime-softening facilities), or transmission between wholesalers. Sometimes referred to a utility use.

R

Reclaimed water Water that has received at least secondary treatment and is reused after leaving a wastewater treatment facility.

Recycled water Water that is used more than one time before it passes back into the natural hydrological system or is discharged into a wastewater system. Also referred to as recirculated water.

Resident population The number of persons who live in a State who consider the State their permanent place of residence. College students, military personnel, and inmates of penal institutions are counted as permanent residents. According to this definition, tourist and seasonal or part-time residents are considered nonresident population.

Residential water use See domestic water use.

Reuse system The deliberate application of reclaimed water for a beneficial or other useful purpose. Reuse may encompass landscape irrigation (such as golf courses, cemeteries, highway medians, parks, playgrounds, school yards, nurseries, and residential properties), agricultural irrigation (such as food and fruit crops, wholesale nurseries, sod farms and pasture grass), aesthetic uses, ground-water recharge, environmental enhancement of surface water and wetland restoration, fire protection, and other useful purposes.

Reverse osmosis The process of removing salts from water using a membrane. With reverse osmosis, the product water passes through a fine membrane that the salts are unable to pass through, and the salt waste (brine) is removed and disposed. This differs from electrodialysis where the salts are extracted from the feed water by using a membrane with an electrical current to separate the ions. During electrodialysis the 
positive ions flow through one membrane, while the negative ions flow through a different membrane, leaving freshwater as the end product. In this report, reverse osmosis includes any water treated through both reverse osmosis and electrodialysis and any water diluted or blended with fresher water that was used to obtain potable water. Also see desalination.

\section{S}

Saline water Water that contains more than $1,000 \mathrm{mg} / \mathrm{L}$ of dissolved solids.

Secondary wastewater treatment The second step in most domestic wastewater treatment systems in which bacteria consume the organic parts of the waste. This treatment removes floating and settleable solids and about 90 percent of the oxygen-demanding substances and suspended solids. Disinfection is the final stage of secondary treatment (U.S. Environmental Protection Agency, 1997, written commun.).

Self-supplied water Water withdrawn from a ground- or surface-water source by a user and not obtained from a public supply.

Septic tank Refers to a buried watertight receptacle constructed to promote the separation of solids, grease, and liquid components of wastewater in the absence of oxygen. The liquid fraction from the septic tank is discharged to a drain field for further treatment or disposal. In Florida, septic tanks are regulated by the Florida Department of Health.

Settling pond A holding pond for wastewater where heavier particles sink to the bottom for removal and disposal.

Sprinkler irrigation A pressurized irrigation system where water is distributed through pipes to the field and applied through a variety of sprinkler heads or nozzles. Pressure is used to spread water droplets above the crop canopy to simulate a rainfall (Izuno and Haman, 1987). These systems include portable and traveling guns, solid or permanent fixtures (overhead or pop ups), center pivots, and periodic moving systems. Also referred to as overhead irrigation. The efficiencies of these sprinkler irrigation systems range from 15 to 85 percent (Smajstrla and others, 1988), however, an average of 70 percent is commonly used for estimating water requirements.
Surface-water disposal Refers to the release of reclaimed water or treated effluent directly into a surface water body (including marshes or wetlands). This does not include water discharged into ponds for holding or percolation purposes (Marella, 1994).

\section{$\mathbf{T}$}

Tail-water runoff Unused irrigation water or rain water that is collected at the base or end of an irrigated system or field in a ditch or impoundment. This water may be reused again for irrigation purposes, be left to evaporate, percolate into the ground, receive treatment, and (or) be discharged to surfacewater bodies.

Thermoelectric power Electrical power generated by using fossil fuel (coal, oil, natural gas or biomass), geothermal, or nuclear energy.

Treated (wastewater) effluent Water that has received primary, secondary, or advanced treatment and is released from a wastewater facility after treatment.

\section{W}

Wastewater A combination of liquid and water-carried pollutants from residential or commercial buildings, industrial plants, and institutions. Wastewater may include any groundwater, surface runoff, or leachate that may be present in the system.

Water transfer Artificial conveyance of water from one area to another across a political or hydrological boundary. This is referred to as an import or export of water from one basin or county to another.

Water use (1) In a restrictive sense, the term refers to water that is actually used for a specific purpose such as domestic use, irrigation, or industrial processing. (2) More broadly, water use pertains to human's interaction with and influence on the hydrologic cycle, and includes elements such as water withdrawals, deliveries, consumptive use, wastewater releases, reclaimed wastewater, return flow and instream use.

Withdrawal Water removed from the ground or diverted from a surface-water source. The amount of water withdrawn may not equal the amount of water used due to water transfers or the recirculation or recycling of the same water. For example, a power plant may use the same water multiple times but withdraw a significantly different amount. 